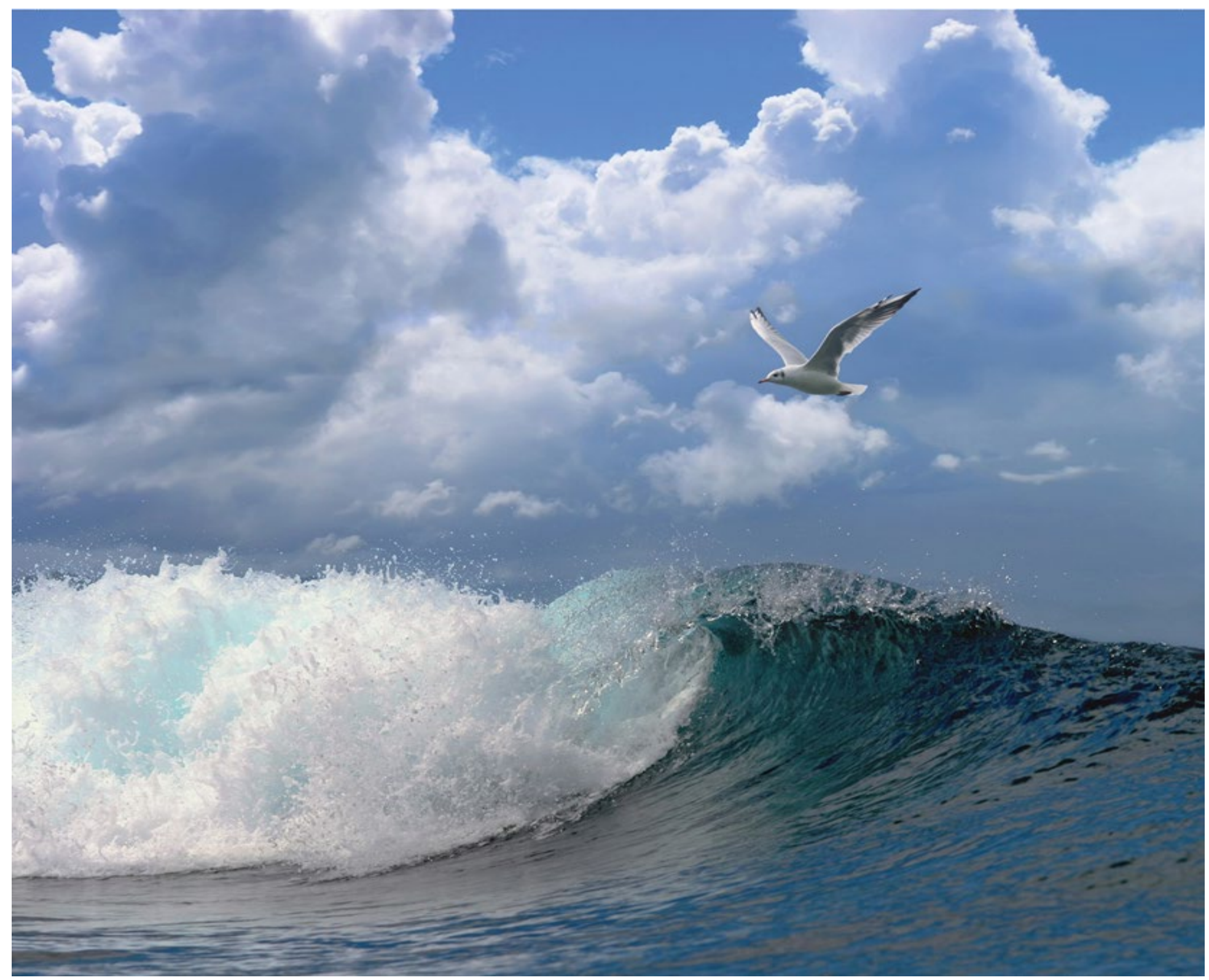

\title{
Ontwikkelingen van het macrozoöbenthos in het Grevelingenmeer 1992-2016
}

Dit onderzoek is uitgevoerd door Wageningen Marine Research in opdracht van en gefinancierd door twee partijen: (1) het Ministerie van Landbouw, Natuur en Voedselkwaliteit, in het kader van het Beleidsondersteunend onderzoekthema 'Natuurambitie Grote Wateren' (projectnummer BO-43-021.03-001) en (2) Staatsbosbeheer als onderdeel van uitvoering onderzoek voor het convenant regiocentrum Yerseke. 


\section{Ontwikkelingen van het macrozoöbenthos in het Grevelingenmeer 1992-2016}

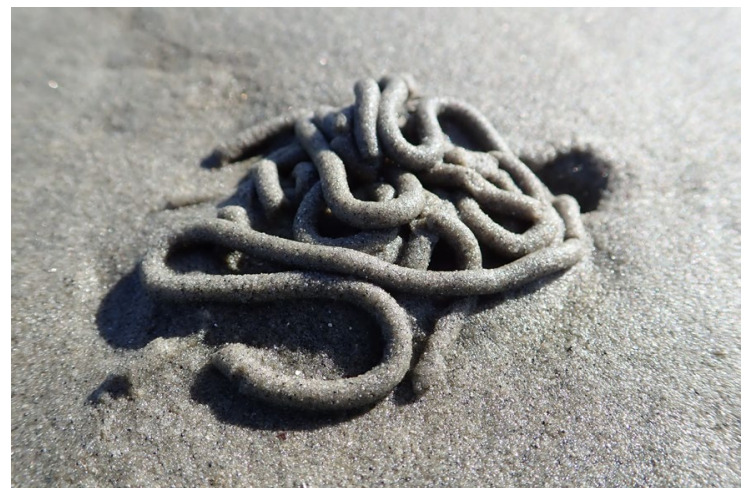

Auteur(s): $\quad$ Ingeborg Mulder, Vincent Escaravage, Marijn Tangelder, Tom Ysebaert

Dit onderzoek is uitgevoerd door Wageningen Marine Research in opdracht van en gefinancierd door twee partijen: (1) het Ministerie van Landbouw, Natuur en Voedselkwaliteit, in het kader van het Beleidsondersteunend onderzoekthema 'Natuurambitie Grote Wateren' (projectnummer BO-43-021.03-001) en (2) Staatsbosbeheer als onderdeel van uitvoering onderzoek voor het convenant regiocentrum Yerseke 
Keywords: macrozoöbenthos, ontwikkelingen, Grevelingenmeer

\author{
Opdrachtgevers: Ministerie van LNV \\ T.a.v.: Jip van Peijpe \\ Bezuidenhoutseweg 73 \\ 2594 AC Den Haag \\ Staatsbosbeheer \\ T.a.v.: Ad van Hees \\ Haven van Bommenede 1 \\ 4316 PC Zonnemaire
}

Dit rapport is gratis te downloaden van https://doi.org/10.18174/471938

Wageningen Marine Research verstrekt geen gedrukte exemplaren van rapporten.

Wageningen Marine Research Wageningen UR is ISO 9001:2015 gecertificeerd.

\title{
(C) Wageningen Marine Research
}

Wageningen Marine Research, onderdeel van Stichting Wageningen Research KvK nr. 09098104,

IMARES BTW nr. NL 8113.83.696.B16

Code BIC/SWIFT address: RABONL2U IBAN code: NL 73 RABO 0373599285
De Directie van Wageningen Marine Research is niet aansprakelijk voor gevolgschade, noch voor schade welke voortvloeit uit toepassingen van de resultaten van werkzaamheden of andere gegevens verkregen van Wageningen Marine Research opdrachtgever vrijwaart Wageningen Marine Research van aanspraken van derden in verband met deze toepassing.

Dit rapport is vervaardigd op verzoek van de opdrachtgever hierboven aangegeven en is zijn eigendom. Niets uit dit rapport mag weergegeven en/of gepubliceerd worden, gefotokopieerd of op enige andere manier gebruikt worden zonder schriftelijke toestemming van de opdrachtgever. 


\section{Inhoud}

$\begin{array}{lr}\text { Samenvatting } & \mathbf{5}\end{array}$

$\begin{array}{llr}1 & \text { Inleiding } & 7\end{array}$

$\begin{array}{lll}1.1 & \text { Achtergrond } & 7\end{array}$

$\begin{array}{ll}1.2 & \text { Aanleiding }\end{array}$

$\begin{array}{llc}1.3 & \text { Doel } & 8\end{array}$

$\begin{array}{llr}1.4 & \text { Disclaimer } & 8\end{array}$

2 Gebiedsbeschrijving $\quad 9$

2.1 Open estuarium $\quad 9$

2.2 Deltaplan 9

$\begin{array}{ll}2.3 \text { Waterbeheer na afsluiten } & 9\end{array}$

$\begin{array}{ll}2.4 \text { Waterkwaliteit } & 10\end{array}$

$\begin{array}{ll}2.5 & \text { Ontwikkeling bodemdiergemeenschap } \\ \end{array}$

$\begin{array}{llr}3 & \text { Werkwijze } & 13\end{array}$

3.1 Veld- en Labwerkzaamheden 13

$\begin{array}{ll}3.2 & \text { Databewerking } \\ 3.3 & 15\end{array}$

$\begin{array}{ll}3.3 \text { Analyses } & 15\end{array}$

$\begin{array}{lll}3.3 .1 & \text { Trendanalyses } & 15\end{array}$

$\begin{array}{ll}\text { 3.3.2 Multivariate analyse } & 16\end{array}$

4 Resultaten $r$

$\begin{array}{llr}4.1 & \text { Samenstelling macrozoöbenthos } & 19\end{array}$

4.2 Soortenrijkdom en dominante soorten $\quad 22$

$\begin{array}{lll}4.3 & \text { Trends in tijd } & 28\end{array}$

4.3.1 Biomassa $\quad 28$

$\begin{array}{lll}4.3 .2 & \text { Dichtheid } & 36\end{array}$

$\begin{array}{lll}4.3 .3 & \text { Voedselgildes } & 41\end{array}$

$\begin{array}{lll}4.3 .4 & \text { Verworming } & 45\end{array}$

$\begin{array}{lll}4.3 .5 & \text { Sediment } & 46\end{array}$

4.4 Verschuiving van bodemgemeenschap $\quad 49$

4.4.1 Basis resultaten van de MDS op basis van de soorten dichtheden 49

$\begin{array}{lll}4.4 .2 & \text { Relatie met omgevingsfactoren } & 50\end{array}$

4.4.3 Verschillen tussen groepen op basis van omgevingsfactoren $\quad 51$

4.4.4 Bijdrage van individuele taxa aan de waargenomen verschillen $\quad 52$

4.5 Vergelijking met het Veerse meer $\quad 53$

$\begin{array}{llr}5 & \text { Conclusies } & 54\end{array}$

6 Discussie en aanbevelingen $\quad 55$

6.1 Ontwikkeling bodemdiergemeenschap 1992-2016 55

$\begin{array}{ll}6.2 & \text { Beperkingen van dit onderzoek } \\ 6.3 & 57\end{array}$

$\begin{array}{ll}6.3 & \text { Aanbevelingen en vervolg } \\ \end{array}$

$\begin{array}{llr}7 & \text { Kwaliteitsborging } & 59\end{array}$

$\begin{array}{lr}\text { Literatuur } & 60\end{array}$ 
Bijlage 1 Overzicht veranderingen macrozoöbenthos 


\section{Samenvatting}

Het Grevelingenmeer is ontstaan toen de voormalige zeearm de Grevelingen werd afgesloten van de Noordzee door de aanleg van de Brouwersdam (1971). Het meer staat in constante verbinding met de Noordzee via de Brouwerssluis. Als gevolg van de beperkte wateruitwisseling in het Grevelingenmeer treden er tijdens de zomerperiode regelmatig zuurstofarme condities op in de diepere delen van het meer. In 2014 heeft het kabinet de ontwerp-RSV vastgesteld waarin het ontwikkelingsperspectief wordt geschetst voor een Grevelingenmeer met gedempt getij van $50 \mathrm{~cm}$ via een extra doorlaat in het noordelijke deel van de Brouwersdam. In maart 2018 heeft het Kabinet een budget gereserveerd voor de realisatie hiervan en is het project Getij Grevelingen gestart om de aanleg van het doorlaatmiddel voor te bereiden. Hiervoor is ook kennis nodig over het huidige functioneren van het ecosysteem en hoe het over de tijd heen geëvolueerd is. Omdat bodemdieren (macrozoöbenthos, organismen die in en op de bodem leven $>1 \mathrm{~mm}$ ) weinig of niet mobiel zijn en snel reageren op veranderingen in het milieu zijn ze interessant als indicator voor het bepalen van de ecologische toestand en veranderingen in het ecosysteem. Bodemdieren vormen daarenboven een belangrijke schakel in het voedselweb van het Grevelingenmeer, o.a. als consument van algen (primaire producenten) en voedselbron voor vogels en vissen.

\section{Aanleiding}

Het ministerie van Landbouw, Natuur en Voedselkwaliteit (LNV) vindt het van belang om meer inzicht te krijgen in de ontwikkeling van het bodemleven als onderdeel van de onderwater natuur in het Natura-2000 gebied Grevelingenmeer en in relatie tot Getij Grevelingen. Daarnaast vindt Staatsbosbeheer als beheerder van de oevers, eilanden en ondiepe zones van het Grevelingenmeer het van belang om een beter begrip te krijgen van de ecologische veranderingen zowel boven als onder water en de effecten ervan op het functioneren van het hele ecosysteem. Daarom hebben zij Wageningen Marine Research gevraagd om een overzicht van de beschikbare data te maken en te analyseren.

\section{Doel}

Het doel van deze studie was het kwantitatief beschrijven van de ontwikkelingen in de bodemfauna in de periode 1992-2016 in het Grevelingenmeer op het gebied van: i) totale biomassa; ii) totale dichtheden; iii) voedselgildes; en iv) bodemdiergemeenschappen. De gebruikte data zijn afkomstig van meetcampagnes die hebben plaatsgevonden als onderdeel van het MWTL-programma dat in het voor- en najaar een inventarisatie maakt van de bodemdieren in het oostelijke en westelijke deel van het Grevelingenmeer. Veranderingen en trends zijn met behulp van statistische modellen en multivariate analyses geanalyseerd voor de periode 1992 - 2016.

\section{Conclusie \& discussie}

Uit de analyses komen als belangrijkste conclusies naar voren:

- Uit de multivariate analyses blijkt dat bijna vijftig jaar na afsluiting van het Grevelingenmeer de bodemdiergemeenschap nog steeds in verandering is, met een structureel verschil tussen het ondiepe stratum t.o.v. de twee diepere strata. Tussen 1992 en 1999 is de bodemdiergemeenschap vergelijkbaar tussen de jaren; daarna zien we grotere veranderingen tussen bepaalde jaren.

- De biomassa in het Grevelingenmeer neemt sinds 1992 significant af tot ongeveer 2008 waarna de biomassa in 2013 weer wat toeneemt, maar nog steeds duidelijk lager is in vergelijking tot de eerste waarnemingsjaren. Daarnaast ligt de biomassa gemiddeld hoger, en fluctueert sterker, in het westelijke deel van het Grevelingenmeer. Mogelijk is de biomassa in het westelijke deel hoger en dynamischer door een betere verversing van het water via de Brouwerssluis. De biomassa in het oostelijke deel neemt ook minder sterk af voor bepaalde phyla. De biomassa in het meer wordt voornamelijk gedomineerd door één enkele soort: het muiltje (Crepidula fornicata). De biomassa van deze soort is over de onderzoeksperiode flink 
gedaald (aandeel: 64\% in 1993 en 29\% in 2010), en de laatste jaren is de Japanse Oester (Magallana gigas) in belang toegenomen (aandeel: 0\% in 1993 en 31\% in 2010).

- De dichtheid fluctueert sterk over de tijd, neemt af in de periode van 1994 tot 2008 waarna de dichtheid weer toeneemt in 2013 en 2016. Meer data zou echter moeten uitwijzen of deze trend zich doorzet of dat het een resultaat is van de verandering in bemonsteringsmethode. De variatie in dichtheden worden voornamelijk veroorzaakt door de seizoenen en in mindere mate door de deelgebieden. De dichtheid is gemiddeld hoger in zowel het voorjaar als in het westelijke deel van het Grevelingenmeer. De dichtheid wordt voornamelijk gedomineerd door wormen (o.a. Oligochaeta, Capitella, Polydora), arthropoda (Monocorophium insidiosum, Microdeutopus gryllotalpa) en weekdieren (Crepidula fornicata, Corbula gibba, Kurtiella bidentata).

- De analyses laten een duidelijke trend zien van biomassa en dichtheid over de diepte met: i) een lagere biomassa en dichtheid in de ondiepe zone, ii) een optimum biomassa en dichtheid rond de 4-6 m onder NAP en, iii) een afname van de biomassa en dichtheid naar de diepere delen. Aannemelijk is dat de lagere biomassa in de ondiepe zone (0-2 m) wordt veroorzaakt door de hydrodynamiek van golven die vestiging en voorkomen van soorten belemmeren doordat ze worden weggespoeld. De afname op grotere diepte kan verschillende redenen hebben waaronder stratificatie. Doordat er nauwelijks uitwisseling plaatsvindt tussen de onderste en bovenste waterlagen kunnen zuurstofarme of zuurstofloze omstandigheden ontstaan bij de bodem doordat zuurstof wordt verbruikt maar niet wordt aangevuld.

Zuurstofloosheid kan, zeker bij langdurig optreden, negatieve gevolgen hebben voor het bodemleven. Dat de biomassa op alle diepten afneemt in de tijd, dus ook in de ondiepe delen (0-2 meter) waar nauwelijks zuurstofloosheid optreedt, impliceert dat veranderingen zich voordoen op het niveau van het hele systeem en dat dit niet per se gerelateerd is aan zuurstofloosheid. Echter nemen zowel biomassa als dichtheden af met toenemende diepte. Enerzijds is dit een natuurlijk verloop in stagnante wateren, maar optreden van zuurstofloosheid zou hier ook een rol kunnen spelen. Omdat de bemonsterde punten in zones liggen waar zuurstofloosheid niet of beperkt optreedt kan hier op basis van deze studie geen uitspraken over gedaan worden.

- De resultaten laten zien dat de term 'verworming' (zoals in eerdere studies wordt gesteld) onjuist is. Verhoudingsgewijs neemt het relatieve aandeel wormen wel toe, maar dat komt omdat het relatieve aandeel schelpdieren afneemt. De afname van schelpdieren is zelfs te herleiden tot de afname van één soort: $C$. fornicata (het muiltje).

- Net als in andere bekkens zoals de Westerschelde, Oosterschelde en Veerse Meer domineren filtrerende soorten (C. fornicata, M. gigas) de biomassa, en bodemetende (deposit feeders) soorten (Oligochaeta, Capitella) de dichtheid in het Grevelingenmeer. Hierop vormt het Grevelingenmeer dus geen uitzondering.

\section{Tot slot}

Dit rapport is het resultaat van een eerste analyse naar ontwikkeling van de bodemdiergemeenschappen in het Grevelingenmeer en kon uitgevoerd worden dankzij steun van LNV, Staatsbosbeheer en eigen investering van WMR. Het vormt een waardevolle stap in het beter begrijpen van ecologische veranderingen in het meer met bodemdieren als cruciale schakel tussen primaire productie en hogere trofische niveau's. Rijkswaterstaat, Staatsbosbeheer en kennisinstituten Deltares en Wageningen Marine Research hebben de ambitie om de systeemkennis van het Grevelingenmeer te verbeteren door het ontwikkelen van een digitale systeemrapportage (als vervolg op eerdere bekkenrapportages). Voorliggend rapport vormt één van de eerste bouwstenen hiervoor. 


\section{$1 \quad$ Inleiding}

\subsection{Achtergrond}

Het Grevelingenmeer is ontstaan toen de voormalige zeearm de Grevelingen werd afgesloten van de Noordzee door de aanleg van de Brouwersdam (1971). Om het zoutgehalte in het meer constant hoog te houden en stratificatie en zuurstofloosheid in de diepe putten te beperken staat sinds 1999 de spuisluis in de Brouwersdam permanent open (Wijsman 2002, W\&B 2012). Desondanks is de ecologische toestand van het Grevelingenmeer in de laatste decennia achteruit gegaan. Als gevolg van de beperkte watercirculatie in het Grevelingenmeer treden er tijdens de zomerperiode regelmatig zuurstofarme condities op in de diepere delen (oude getijdengeulen) van het meer. Deze zuurstofarme condities hebben gevolgen voor de bodemdiergemeenschappen (Lengkeek et al. 2007) en via het voedselweb mogelijk ook voor vissen en vogels.

De bodemdieren vormen een belangrijke schakel in het voedselweb tussen primaire productie en hogere trofische niveaus (Figuur 1). Vele bodemdierensoorten halen hun voedsel uit het water en het sediment (algen (fytoplankton, microphytobenthos), detritus etc.) en vormen tegelijkertijd een belangrijke voedselbron voor benthivoren waaronder vissen en vogels. Daarnaast worden bodemdieren vaak gebruikt als indicatoren van de ecologische status van mariene milieus (bv. Kaderrichtlijn Water, Mariene Strategie) omdat de meeste bodemdieren sedentair zijn (niet of weinig mobiel) en hun aanwezigheid (maar ook afwezigheid, dichtheid, leeftijdsopbouw, etc.) daardoor typerend is voor bepaalde omgevingsomstandigheden onder invloed van natuurlijke en antropogene verstoringen.

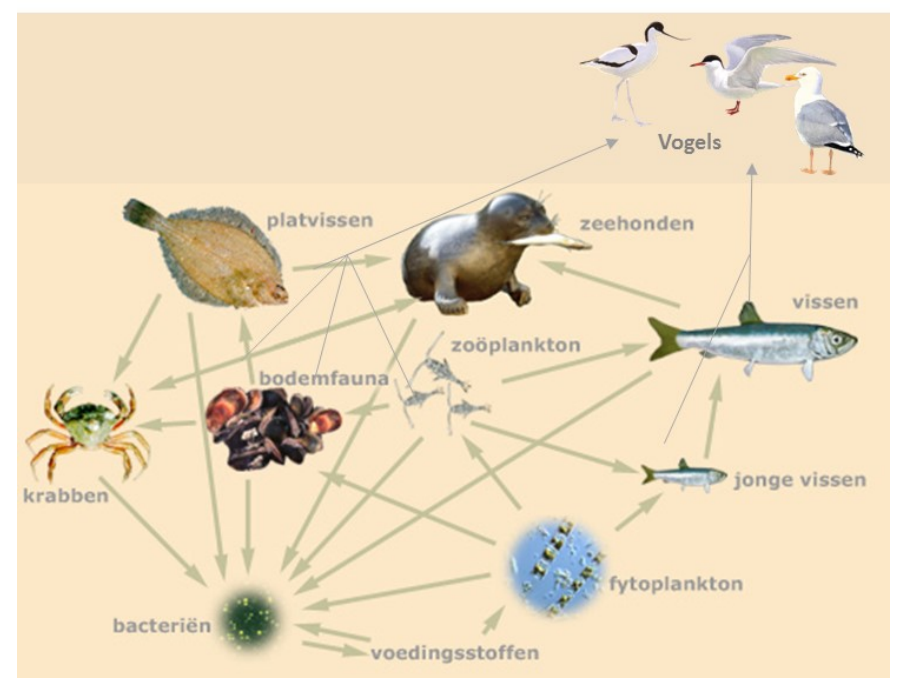

Figuur 1. Weergave van een vereenvoudigd voedselweb. De bodemdieren vormen een belangrijke schakel tussen de lagere trofische niveaus (algen, zoöplankton, bacteriën) en hogere trofische niveaus (vissen, vogels, zeezoogdieren).

\subsection{Aanleiding}

Ondanks het permanent openstellen van de spuisluis in de Brouwersdam is er niet voldoende hydrodynamische energie om de hele waterkolom te mengen van het oppervlak tot aan de bodem van de diepe geulen. De waterkolom raakt gestratificeerd met als gevolg zuurstofloosheid en schade aan het onderwaterleven. In 2014 heeft het kabinet de Ontwerp-Rijksstructuurvisie Grevelingen en Volkerak-Zoommeer (ontwerp-RSV) vastgesteld waarin het ontwikkelperspectief wordt geschetst voor een Grevelingenmeer met gedempt getij van $50 \mathrm{~cm}$ via een extra doorlaat in het noordelijke deel van de Brouwersdam. In maart 2018 heeft het Kabinet een budget gereserveerd voor de realisatie hiervan 
en medio 2019 zal naar verwachting de planuitwerkingsfase starten. Verder is in januari 2017 de Flakkeese Spuisluis in de Grevelingendam geopend om de verblijftijden van het water in het oostelijk deel van het meer te verkorten.

Allereerst wenst het ministerie van Landbouw, Natuur en Voedselkwaliteit (LNV) om meer inzicht te krijgen in de ontwikkeling van het bodemleven als onderdeel van de onderwater natuur in het Natura 2000 gebied Grevelingenmeer en in relatie tot de planvorming over het introduceren van gedempt getij in het project Getij Grevelingen. Het genereren van kennis op dit gebied is in lijn met de door LNV opgestelde beleidsvisie Natuurambitie Grote Wateren (2014) en is dit onderzoek opgenomen binnen 'Beleidsondersteunend Onderzoek' dat Wageningen Marine Research uitvoert voor LNV. Daarnaast past dit onderzoek ook goed binnen de Programmatische Aanpak Ecologie Grote Wateren (PAEGW) (Feddes et al., 2018) waarin kennisontwikkeling over systeem functioneren en relatie met mogelijke invoering van gedempt getij van belang is.

Ten tweede vindt Staatsbosbeheer als beheerder van de oevers, eilanden en ondiepe zones van het Grevelingenmeer het van belang om een beter begrip te krijgen van de ecologische veranderingen zowel boven als onder water en de effecten ervan op het functioneren van het hele ecosysteem. Deze ambitieuze exercitie wordt opgepakt in een aanverwant spoor met samenwerkende partijen (o.a. Rijkswaterstaat, Staatsbosbeheer, Deltares, Wageningen Marine Research) met als beoogd resultaat de totstandkoming van een digitale systeemrapportage voor het Grevelingenmeer. De huidige analyse van de bodemdieren is een eerste belangrijke stap in dit geheel en daarom heeft Staatsbosbeheer financieel bijgedragen aan dit onderzoek.

Tot slot heeft Wageningen Marine Research ook eigen middelen geïnvesteerd in het huidige project als een bijdrage voor een beter begrip van het ecosysteem van het Grevelingenmeer.

\subsection{Doel}

Sinds de afsluiting van het Grevelingenmeer is meerdere malen onderzoek gedaan naar de ontwikkeling van bodemdieren in de perioden 1980-1990 (Holland 1991), 1990-1995 (Wattel 1996), 1996-2001 (Hoeksema 2002), 1990-2000 (Schaub et al. 2002), 1990-2008/2010 (Wetsteijn, 2011) en 1990-2010 (Arcadis 2013). Tot nu toe is er gekeken naar de algemene trends van biomassa en dichtheden in het Grevelingenmeer in de periode 1990 tot 2010. De behoefte bestaat om verder in te gaan op de ruimtelijke (diepte, geografische locatie) en temporele veranderingen op het niveau van de soortengroepen (bv. schelpdieren, wormen, etc.), voedselgildes (bv. filterfeeders, detritivoren etc.) en gemeenschappen. Dit rapport doet verslag van veranderingen in de karakteristieken van de bodemdierengemeenschappen, in het vervolg 'het macrozoöbenthos' van het Grevelingenmeer in de periode van 1992 tot 2016 (dus nog voor de opening van de Flakkeese Spuisluis).

Het doel van deze studie is:

Het kwantitatief beschrijven van de ontwikkelingen in het macrozoöbenthos in de periode 1992-2016 in het Grevelingenmeer op het gebied van:

a. Totale macrozoöbenthos biomassa

b. Totale macrozoöbenthos dichtheden

c. Soorten/Soortengroepen en Voedselgildes

d. Macrozoöbenthos gemeenschappen

\subsection{Disclaimer}

Analyse van een dergelijke meerjarige macrozoöbenthos monitoringdataset is een zeer bewerkelijke exercitie onder andere door het grote aantal waargenomen soorten en de hoge graad van variatie die typerend is voor (monitoring van) het macrozoöbenthos. Het is daarom van belang te benadrukken dat dit onderzoek gezien moet worden als een eerste stap in het begrijpen van de veranderingen in het macrozoöbenthos van het Grevelingenmeer. Een meer diepgaande analyse en discussie i.r.t. andere (systeem)veranderingen zal in de Systeemrapportage Grevelingen aan bod komen. 


\section{$2 \quad$ Gebiedsbeschrijving}

\subsection{Open estuarium}

Tot 1964 was de Grevelingen een estuarien getijdenlandschap met uitgestrekte slikken, platen en schorren. Zout Noordzeewater kwam binnen via de monding en via de oostelijke verbinding met de Oosterschelde. Zoet water van de Rijn en Maas werd aangevoerd via het Krammer-Volkerak. Het zoutgehalte was meer dan $10 \mathrm{~g} \mathrm{Cl}^{-1}$ en het getijverschil gemiddeld $2.3 \mathrm{~m}$.

\subsection{Deltaplan}

Na de watersnoodramp van 1953 werden plannen gemaakt om de Grevelingen volledig af te sluiten ten behoeve van de landbouw en waterveiligheid. In 1964 is de Grevelingen afgesloten van de zoetwaterafvoer van de grote rivieren door de aanleg van de Grevelingendam en veranderde de Grevelingen tijdelijk van een estuarium in een open zeearm. Er kwam alleen nog zout water via de monding binnen, waardoor de zoet-zoutgradiënt verdween en er een open zeearm met getij ontstond. In 1971 is de Grevelingen afgesloten van de Noordzee door de aanleg van de Brouwersdam. Door deze afsluiting is het grootste zoutwatermeer van West-Europa ontstaan, het Grevelingenmeer, waar de invloed van het getij echter is verdwenen en de waterbeweging en de menging voornamelijk wordt beïnvloed door wind. De voormalige slikken en platen vielen droog en daardoor ontstonden eilanden zoals de Veermansplaat, Hompelvoet en flauw aflopende oevers langs de randen zoals de Slikken van Flakkee.

\subsection{Waterbeheer na afsluiten}

Door een neerslagoverschot en lozing van relatief zoet polderwater werd het Grevelingenmeer na 1971 steeds zoeter. De verzoeting had een slechte invloed op de waterkwaliteit van het meer. Twee weken na de sluiting van de Grevelingen vond er onderwater een massale sterfte plaats van planten en dieren waarvan de gevolgen ook bovenwater zichtbaar waren. Om de aanwezige zoutwaterlevensgemeenschappen te redden werd er besloten om spui- en verversingssluizen te bouwen in de dammen om het meer te kunnen verversen met Noordzeewater. In de Brouwersdam zijn sluiskokers gebouwd die in 1978 zijn voltooid en in gebruik zijn genomen, de Brouwerssluis. In 1979 stond de spuisluis het gehele jaar open om het zoutgehalte in het Grevelingenmeer te verhogen. Vanaf 1980 werd de spuisluis vanaf april tot er met september gesloten en in de periode oktober tot en met maart geopend om de kans op stratificatie en zuurstofloosheid in de zomer in de diepe putten in het Grevelingenmeer te verminderen (Wetsteijn, 2011). In het bekkenrapport (1990-1995) 'Grevelingen: uniek maar kwetsbaar' (Wattel 1996) werd desondanks aangegeven dat de beperkte doorspoeling nog steeds een groot zorgpunt was. Tegelijkertijd werden de inzichten in het proces van stratificatie genuanceerder en leek het jaarrond openzetten van de spuisluis een goed alternatief. Vanaf april 1999 staat de spuisluis permanent open met een maximale sluiting van 30 dagen op verzoek van de palingvissers, om het uitrekken van de schieraal te voorkomen. Sinds 2006 is deze regeling echter veranderd en staat de sluis nu jaarrond open en kan de schieraal vrijuit migreren (Wetsteijn, 2011). Naast palingvisserij worden er ook commercieel oesters gekweekt in het Grevelingenmeer op afgebakende percelen met een totale oppervlakte van 550 ha (Grevelingen 2010). Ondanks dat het Grevelingenmeer nu een stabiel en hoog zoutgehalte heeft, heeft de spuisluis echter een gering effect op de menging van de waterkolom (Nolte et al. 2008, Wetsteijn 2011). Met de spuisluis wordt ook het gemiddeld waterpeil van $-0.2 \mathrm{~m}$ (grenswaarden: -0.10 tot $-0.30 \mathrm{~m}$ ) NAP in het Grevelingenmeer geregeld. Het middenpeil van - $0.2 \mathrm{~m}$ NAP wordt in het broedseizoen (periode april-juli) met $6 \mathrm{~cm}$ verlaagd zodat broedvogels op de kale delen kunnen broeden. In de periode september-februari in drie perioden van drie weken gestuurd op een middenpeil van $-0.16 \mathrm{~m}$. In werkelijkheid vertoont het waterniveau schommelingen. Het peil mag gedurende het hele jaar 
fluctueren tussen maximaal -0.10 m NAP en minimaal -0.30 m NAP, maar daarbij wordt het zomer- en winterpeil wel zo goed als mogelijk nagestreefd (Rijkswaterstaat, 2013).

Naast de spuisluis is er in 1983 ook een hevel aangelegd in de Grevelingendam, de Flakkeese sluis (Bannink et al. 1984; Visser 1995). De hevel is oorspronkelijk aangelegd om het zoutgehalte in het Zijpe en de Krabbenkreek in de Oosterschelde bij de sluiting van de Philipsdam in 1986 op een aanvaardbaar niveau te houden. Omdat de Brouwerssluis voorzag in het voldoende op peil houden van het zoutgehalte is de hevel alleen gebruikt voor een aantal proeven. De hevel in de Grevelingendam is sinds 1987 buiten gebruik gesteld. Echter, in 2017 is de Flakkeese Spuisluis in de Grevelingendam opnieuw in gebruik genomen om de waterkwaliteit in het oostelijk deel van het Grevelingenmeer te verbeteren. Oorspronkelijk kon het water via de Flakkeese Spuisluis alleen van het Grevelingenmeer naar de Oosterschelde stromen. De sluis is nu omgebouwd naar een tweezijdig doorlaatmiddel waardoor het water nu ook van de Oosterschelde naar het Grevelingenmeer kan stromen. Hierdoor ontstaat een betere menging in het oostelijke deel van het meer wat mogelijk ten gunste gaat van de zuurstofconcentraties met als een gevolg een betere waterkwaliteit.

\subsection{Waterkwaliteit}

Ondanks herhaaldelijke aanpassingen in het beheer van de Brouwerssluis ten behoeve van de waterkwaliteit is de ecologische toestand van het Grevelingenmeer in de laatste decennia verder achteruit gegaan (Wetsteijn 2011, Arcadis 2013). Vóór 1999 trad stratificatie, de gelaagdheid van de waterkolom, doorgaans op van mei tot augustus in de diepe putten (op 15-20 m diepte) van Scharendijke en Den Osse met als voornamelijk oorzaak het verschil in temperatuur tussen de waterlagen (Wetsteijn 2011). Het zoutgehalte speelde geen grote rol bij de stratificatie gezien het verschil tussen de oppervlaktelaag en diepe laag maar 1-2 g chloride per liter was. Na 1999 wordt het water jaarrond ingelaten. Het relatieve warme Noordzeewater is zouter (zwaarder) en zuurstofrijker dan het water in het Grevelingenmeer en zakt daarom naar de bodem. Desondanks speelt zoutstratificatie een geringe rol doordat het zoutgehalte van het inkomende Noordzeewater niet veel verschilt van het zoute water van de diepe laag. Temperatuurstratificatie speelt daarom een belangrijkere rol dan de zoutstratificatie in het Grevelingenmeer (Wetsteijn 2011). De stratificatie minimaliseert de uitwisseling tussen twee watermassa's en daarmee ook de uitwisseling van bijvoorbeeld zuurstof (Van der Kamer en Van der Meulen 1985). Dit kan leiden tot zuurstofarme of zuurstofloze condities in de diepere delen van het meer wat negatieve gevolgen heeft op het bodemleven in het Grevelingenmeer (Figuur 2) (Lengkeek et al. 2007; Didderen et al. 2013).

Zuurstofloze condities treden voornamelijk op tijdens het zomerhalfjaar in de diepere geulen van het Grevelingenmeer. Afhankelijk van de windcondities en de temperatuur kan de zuurstofloosheid zich uitbreiden naar de ondiepere delen van het meer (Wetsteijn 2011). Ook biologische processen zijn hierop van invloed bv. door het bezinken van afgestorven wieren en algen die zorgen voor een extra zuurstofvraag (observaties van Bureau Waardenburg). Het inlaten van Phaeocystis-bloeien door de spuisluis tijdens het voorjaar heeft ook een versterkend effect op de zuurstofloosheid (Wijsman 2002; Wetsteijn 2011). Op de bodem van het Grevelingenmeer worden regelmatig witte matten aangetroffen die veroorzaakt worden door verschillende soorten van de zwavelbacterie Beggiatoa (Didderen et al. 2013). In het beheer van het Grevelingenmeer wordt ernaar gestreefd om het totale oppervlak aan zuurstofarme bodem minder dan 5\% van het totale oppervlak te houden (Wetsteijn 2011), al wordt dit niet elk jaar gehaald (Lengkeek et al. 2007). 


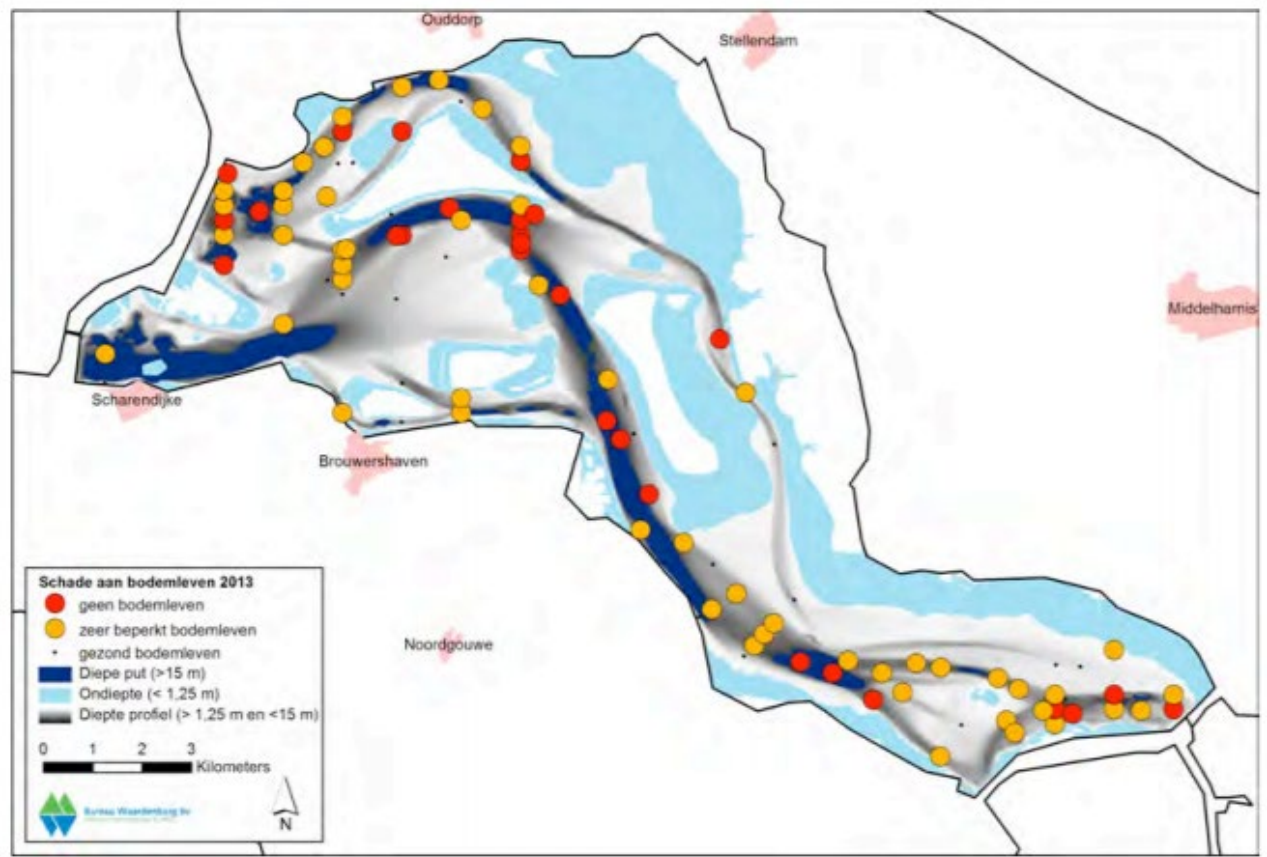

Figuur 2. Verspreiding zichtbare schade aan bodemleven op basis van visuele inspectie door duikers van Bureau Waardenburg, augustus 2013 (uit Didderen et al. 2013).

Lage zuurstofconcentraties ( $<3 \mathrm{mg} \mathrm{l}^{-1}$ ) in het Grevelingenmeer treden meestal begin mei voor het eerst op in de westelijk gelegen diepe putten van Scharendijke en Den Osse waar rond die tijd over het algemeen stratificatie optreedt op een diepte van ongeveer 15-20 m. In juni-juli treden ook zuurstofarme condities op in de meer oostelijk gelegen kleinere putten (zoals de putten bij Dreischor en Herkingen) en andere ondiepere delen van het meer (tot een diepte van ongeveer 7-10 m). Het maximale oppervlakte aan zuurstofarm areaal in het Grevelingenmeer wordt meestal aangetroffen eind juni- begin juli (Figuur 3). De zuurstofarme condities duren over het algemeen twee tot drie maanden (Hoeksema 2002).

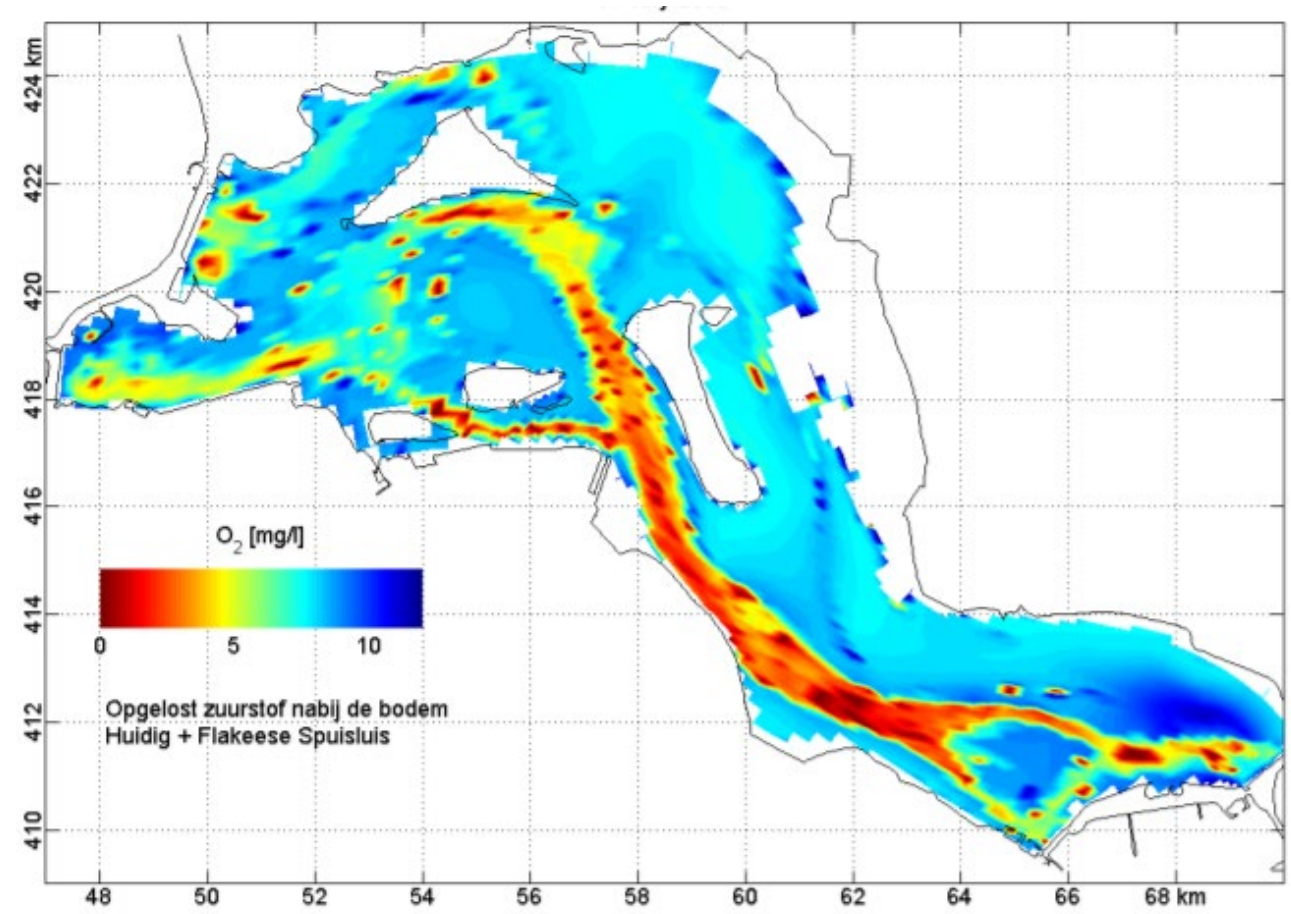

Figuur 3. Zuurstofconcentraties (na in gebruik name van de Flakkeese Spuis/uis) in de onderste laag van de waterkolom in het Grevelingenmeer op 7 juli, een moment waarop de laagste zuurstofconcentraties optreden (uit Nolte et al. 2008). 


\subsection{Ontwikkeling bodemdiergemeenschap}

De bodemdieren van het zachte substraat (de zandige bodem van het Grevelingenmeer) worden sinds 1990 bemonsterd binnen het MWTL monitoringsprogramma (Craeymeersch et al. 1992, Sistermans et al. 2009, Leewis et al. 2015). Op basis van deze gegevens kunnen we het macrozoöbenthos van het Grevelingenmeer als volgt karakteriseren. Qua soortensamenstelling tellen de wormen de meeste soorten gevolgd door geleedpotigen (vooral kreeftachtigen) en weekdieren (vooral schelpdieren). Vergeleken met die drie groepen zijn de andere diergroepen vertegenwoordigd door beduidend minder soorten. Waar vooral de wormen en de geleedpotigen het macrozoöbenthos numeriek domineren is de biomassa sterk gedomineerd door de weekdieren. Het overgrote deel van de bodemdieren filtreren hun voedsel uit het water (ongeveer 90\% van de biomassa aan bodemdieren) (Hoeksema 2002), dit komt door de sterke vertegenwoordiging van schelpdieren.

De gemiddelde totale biomassa in de periode 1990-2000 is relatief hoog te noemen, vergelijkbaar met rijke delen van de Waddenzee en hoger dan wat er in de Ooster- en Westerschelde wordt gevonden (Hoeksma 2002). Van de weekdieren is het muiltje (Crepidula fornicata) de belangrijkste soort, zowel in aantallen als in gewicht. Bij de wormen domineren de kleinere soorten in aantallen, zoals draadwormen (Capitella capitata) en borstelarme ringwormen (Oligochaeta) en is qua biomassa de zager (Alitta virens) dominant. Hoewel weinig veranderingen zichtbaar zijn in de opbouw van de bodemdiergemeenschap in de periode 1990-2000 met voornamelijk dominantie van schelpdieren, kreeftachtigen en wormen, zijn er wel duidelijke verschuivingen waar te nemen op het niveau van de soortensamenstelling. Over die periode is er een afname van de biomassa van schelpdieren en slakken te zien waaronder de mossel (Mytilus edulis), de platte oester (Ostrea edulis), de kokkel (Cerastoderma edule), het wadslakje (Peringia ulvae), de gevlochten fuikhoorn (Tritia reticulatus) en de alikruik (Littorina littorea). De Japanse oester (Magallana gigas) is juist in opkomst (Hoeksema 2002). Volgens Schaub et al. (2002) lijkt het Grevelingenmeer minder geschikt geworden voor soorten die voedsel uit het water filteren aangezien dichtheden achteruit gaan. De afsluiting van het gebied zou hier een oorzaak van kunnen zijn. Bij minder waterbeweging zakt zwevend materiaal eerder naar de bodem waarvan organismen die van depositie leven kunnen profiteren (Schaub et al. 2002). In die periode vinden er ook verschuivingen in de soortensamenstelling van de wormen plaats met een afname voor een aantal soorten (o.a. de slangpier Capitella capitata) en een aanzienlijke toename voor andere soorten (o.a. de zeeduizendpoot Alitta succinea) (Schaub et al. 2002). Door Sistermans et al. (2006) wordt in de periode tussen 1990-2006 een zeer significante afname van de totale aantallen bodemdieren en biomassa in het Grevelingenmeer geconstateerd. De neerwaartse trend in bodemdiergemeenschappen waargenomen in de ondiepe zone tussen 0-2 meter vanaf 1990 en in de 2-6 meter zone vanaf 1999 (Wetsteijn, 2011) lijkt niet direct gerelateerd te zijn aan zuurstofloze condities die vanaf 5 meter waterdiepte op kunnen treden. Op basis van een analyse in 2013 lijkt deze dalende trend in biomassa aan bodemdieren van de ondiepe zone zich voort te zetten (Kater \& Van Onselen 2013). De toename van enkele wormensoorten, zoals besproken bij Schaub et al. (2002), lijkt zich door te zetten tot 2008 (Wetsteijn 2011). Op basis van monitoringsgegevens uit 2013 is het relatieve aandeel van dichtheden wormensoorten in de zone 0-2 $\mathrm{m}$ in de periode 2010-2013 hoog maar dit komt ook door afname van kreeftachtigen en overige soorten (Leewis et al. 2013). De auteurs geven geen duidelijke verklaring voor deze verschuiving naar voren behalve de constatering dat er nog geen evenwichtssituatie is bereikt en er mogelijke een relatie is met waterkwaliteit, veranderde bodemsamenstelling, en verontreinigingen in het water. 


\section{Werkwijze}

\subsection{Veld- en Labwerkzaamheden}

Als onderdeel van het MWTL-programma vindt er sinds 1990 in het voor- en najaar een inventarisatie plaats van het macrozoöbenthos in het oostelijk en westelijk deel van het Grevelingenmeer met als doel inzicht te krijgen in de ruimtelijke en temporele variatie van de benthische fauna en om mogelijke trends te achterhalen (Figuur 4, Tabel 1).

Tabel 1. Overzicht MWTL meetcampagnes betreft jaartallen (Jaar), uitvoerende partijen (Inst.), jaren met vaste $(V)$ of random $(R)$ meetpunten (Loc.) en bemonsteringsmethoden voor de ondiepe ( $0-2 \mathrm{~m})$ en diepere delen (>2 m). In 2013 is er voor het eerst bemonsterd met een andere methoden (rode stippellijn).

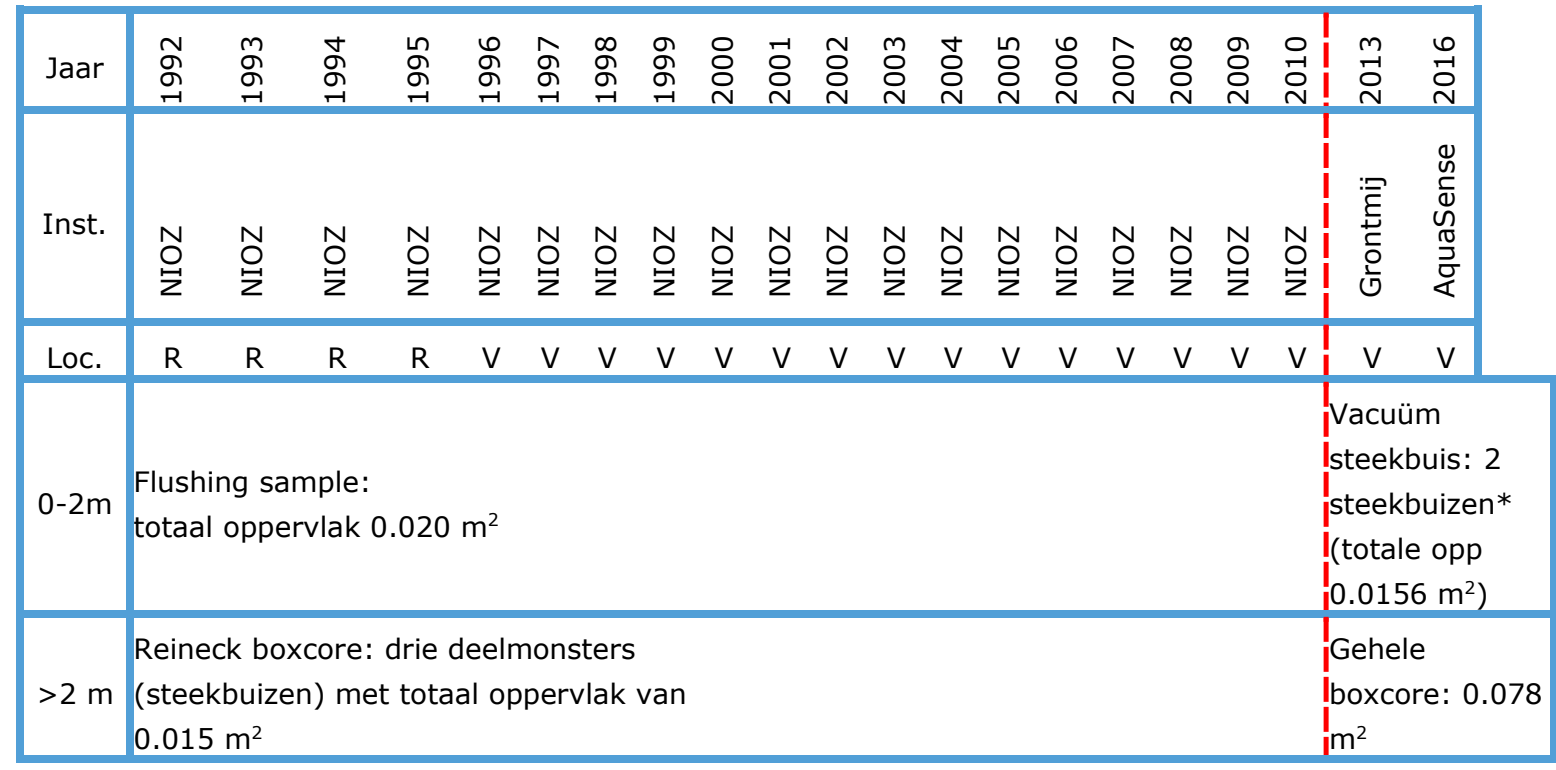

*In voorjaar 2013 is slechts één steek genomen i.p.v. de vereiste twee.

Resultaten van deze meetcampagnes zijn verwerkt in diverse rapporten met het meest recentelijke overzicht in Leewis et al. (2015). De gebruikte MWTL-biomonitoringsgegevens van de macrozoöbenthos zijn aangevraagd bij Helpdesk Water gehuisvest bij Rijkswaterstaat Water, Verkeer en Leefomgeving (RWS WVL). De bemonstering en monsterverwerking is tot er met 2010 uitgevoerd door de monitoring Taakgroep van het NIOZ en daarna door Grontmij in 2013 en Eurofins-AquaSense in 2016 (Tabel 1).

Veldwerk: De bemonstering van het macrozoöbenthos vindt plaats binnen twee deelgebieden van het Grevelingenmeer. Het ene gebied is gelegen in het westelijke deel van het meer en staat onder invloed van het Noordzeewater dat binnenkomt via de Brouwerssluis. Het andere gebied is gesitueerd in het oostelijke deel van het meer waar minder waterbeweging optreedt. Sinds de opening van de Flakkeese Spuisluis in 2017 vindt ook hier meer menging plaats met Oosterschelde water (Figuur 4). In beide deelgebieden worden de vastgestelde monsterlocaties evenredig verdeeld over drie diepte strata: 0-2 m, 2-6 m en dieper dan $6 \mathrm{~m}$ (t.o.v. NAP = zomerpeil + 0.10 m) (Sistermans et al. 2009). In elk van de strata worden 10 monsters genomen alhoewel deze verdeling in de werkelijkheid niet altijd gehaald wordt. Vooral op het grensgebied tussen twee dieptestrata kan het een uitdaging zijn om precies op de van te voren bepaalde coördinaten te bemonsteren waardoor meetpunten soms dieper of ondieper genomen zijn en daardoor in een andere diepte strata kwamen te liggen (maar niet hier tot gerekend worden). Dit kan mogelijk gevolgen hebben voor de analyse van gegevens per diepte strata. In hoeverre dit gevolgen heeft voor de resultaten is onduidelijk. 


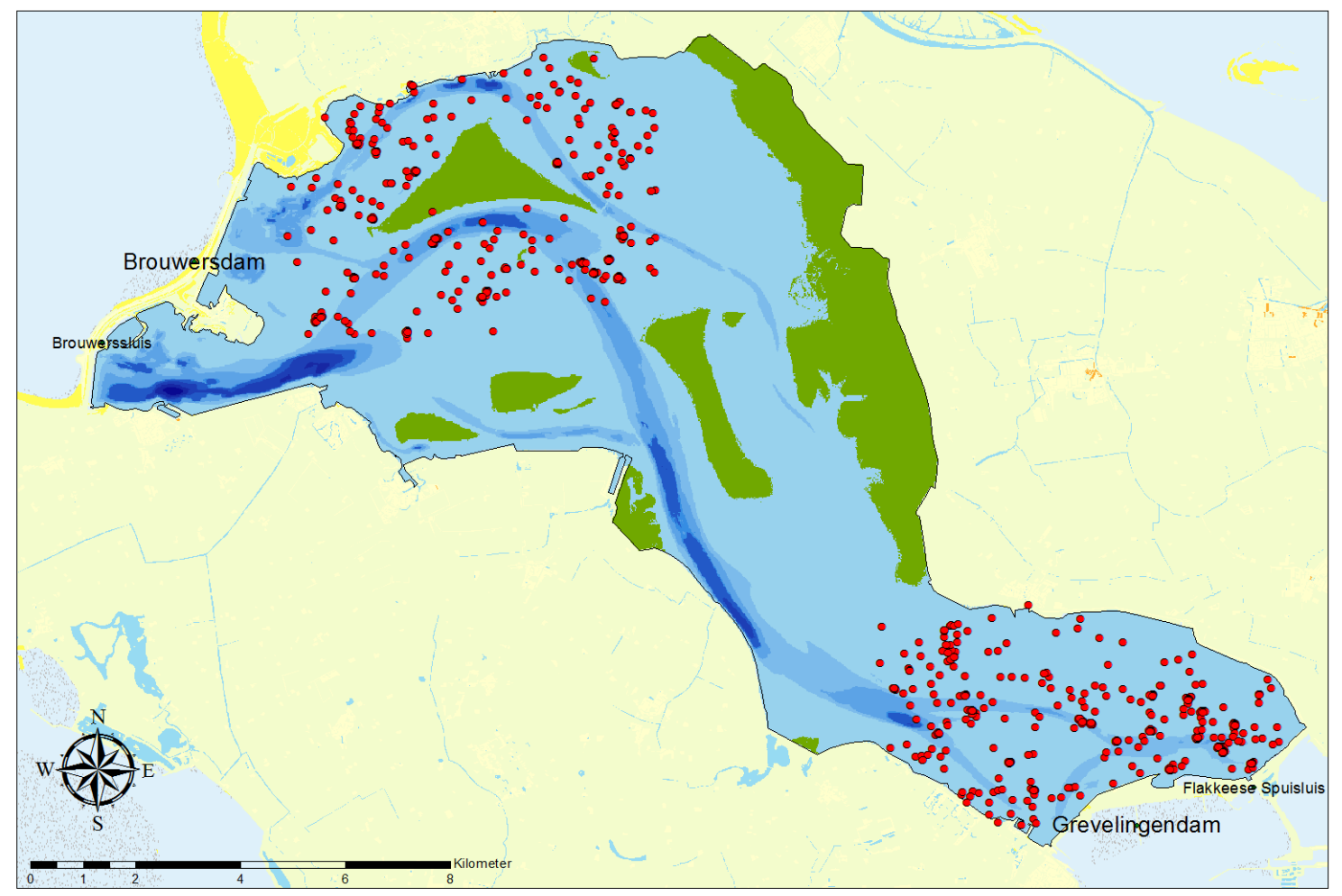

Figuur 4. Ligging van de macrozoöbenthos bemonsteringspunten (rood) in het oostelijk en westelijk deel van het Grevelingenmeer in de periode 1992 tot 2016.

De bemonstering vindt tweemaal per jaar plaats, eenmaal in het voor- en eenmaal in het najaar. Sinds 1994 wordt in ieder deelgebied en binnen elk dieptestratum op vastgestelde locaties bemonsterd. Dit resulteert in 120 monsters per jaar, 60 in het voorjaar en 60 in het najaar. Na 2013 is de jaarlijkse macrozoöbenthosmonitoring van het MWTL programma teruggeschroefd naar $1 \times$ per drie jaar. Bijna alle stations tot een diepte van $2 \mathrm{~m}$ zijn bemonsterd met een zogenaamde 'flushing sampler' $\left(\varnothing 16 \mathrm{~cm}\right.$ ) met een oppervlakte van $0.020 \mathrm{~m}^{2}$ terwijl de twee diepere strata bemonsterd worden met een Reineck box-corer. Uit elke box-corer worden drie deelmonsters genomen met een ronde buis $\left(\varnothing 8 \mathrm{~cm}\right.$ ) met een totaal oppervlakte van $0.015 \mathrm{~m}^{2}$. Echter in 2013 zijn de bemonsteringmethoden aangepast en zijn de monsters in het ondiepe deel ( $<2$ meter) genomen met een vacuüm steekbuis $\left(0.0078 \mathrm{~m}^{2}\right.$, twee monsters per locatie) en is voor de diepere strata elke boxcorer voor het eerst in zijn geheel $\left(0.078 \mathrm{~m}^{2}\right.$; er zijn geen deelmonster genomen) uitgespoeld en meegenomen. Daarmee is het totale bemonsteringsoppervlak vooral in de diepere strata fors toegenomen (x5). De monsters worden aan boord uitgespoeld op een $1 \mathrm{~mm}$ zeef waarna het residu in $\mathrm{pH}$-geneutraliseerde formaline wordt bewaard.

Laboratorium: In het laboratorium zijn de monsters vervolgens nagespoeld met zeewater op een $500 \mu \mathrm{m}$ zeef, gekleurd met bengaals rose en vervolgens gesorteerd en gedetermineerd. De monsters zijn verdeeld in twee fracties met behulp van een $3 \mathrm{~mm}$ zeef waarna dieren uit de residu worden gezocht met het blote oog voor de grove fractie en met behulp van een binoculair voor de fijne fractie (Escaravage et al. 2011). Identificatie is verricht door de uitvoerende partijen: NIOO/NIOZ (19922010), Grontmij (2013) en Eurofins-AquaSense (2016) (Tabel 1). Het datarapport over de bemonstering in 2016 is nog niet beschikbaar.

Tot en met 2010 werden alle dieren, met uitzondering van Oligochaeta, Actiniaria en Nemertea, zo mogelijk tot op soortniveau gedetermineerd, terwijl in 2013 werd getracht om de organismen van alle groepen tot op soortniveau te determineren (Leewis et al. 2015). Identificatie op soort niveau is echter niet altijd mogelijk omdat bijvoorbeeld alleen fragmenten van het dier aanwezig waren (bv alleen de kop of staart) of het dier was nog in een juveniel (klein) stadium waardoor belangrijke kenmerken ontbreken. Als de identificatie op soortniveau niet mogelijk is worden organismen tot het eerstvolgende hogere taxonomische niveau gedetermineerd. Voor elke soort is de dichtheid en biomassa bepaald. 
Door enkele aanpassingen van het bemonsteringsprotocol en het analyseprotocol in 2013 zijn er enkele taxa, die in de soortenlijsten verschijnen vanaf 2013 (Leewis et al. 2015). Zo wordt er vanaf 2013 een volledig boxcore monster meegenomen, waar er in eerdere jaren twee steekbuizen uit een boxcorer werden gestoken. Grote schelpdieren zoals de Japanse oester zijn hierdoor in zijn geheel meegenomen (Leewis et al. 2015). Hierdoor zijn er ook taxa meegenomen van harde substraten, zoals de gekerfde zeepok (Balanus crenatus). Ook is het analyseprotocol aangepast, waardoor sessiele organismen, zoals zeepokken worden gedetermineerd en de aanwezigheid wordt gerapporteerd (Leewis et al. 2015).

Biomassa werd op één van de volgende manieren bepaald (Escaravage et al. 2011):

- $\quad$ Direct bepalen van het asvrij drooggewicht (ADW)

- $\quad$ Met behulp van lengte-gewicht relaties

- $\quad$ Door het converteren van het natgewicht in asvrij drooggewicht

\subsection{Databewerking}

Door het ontbreken van een groot aantal biomassabepalingen in de MWTL 2016 dataset op het moment van de data-analyse, konden die gegevens niet meegenomen worden in de analyse m.b.t. de biomassa. Tevens zijn de gegevens uit het voorjaar van 1994, gekenmerkt door extreme hoge aantallen (uitschieters) als gevolg van het (late) tijdstip van de bemonstering middenin een enorme broedval (Schaub et al. 2002; Wetsteijn, 2011) buiten beschouwing gehouden. Voorafgaande aan de analyses werden de gegevens onderworpen aan controles op fout ingevoerde data en/of uitschieters door middel van visuele inspectie van grafieken per seizoen, deelgebied en dieptestratum. Naar aanleiding hiervan zijn twee uitschieters niet meegenomen in de analyse (Magallana gigas, $347 \mathrm{~g} / \mathrm{m}^{2}$, voorjaar 2000; Magallana gigas, $1213 \mathrm{~g} / \mathrm{m}^{2}$, voorjaar 2010) welke zorgden voor een misrepresentatie van de trends.

In dit rapport is gekeken naar de ontwikkelingen van het macrozoöbenthos over een lange tijdsperiode (1992-2016) waarin soorten namen/afstamming, door voortschrijdend inzicht in de taxonomie, mogelijk zijn veranderd. Daarom is de gehele soortenlijst gecheckt aan de hand van de 'World register of marine species' (WORMS) waar de meeste recente soortennamen en mogelijke aanpassingen staan aangegeven. Bijvoorbeeld, de soortnaam Crassostrea gigas is in 2016 veranderd naar Magallana gigas. Om mogelijke effecten van het determineren van soorten door verschillende instanties te beperken, zijn de soorten Arenicola defodiens en Arenicola marina alleen tot op geslachtsniveau geanalyseerd. Daarnaast wordt Magallana gigas pas sinds 2013 op soortsniveau gedetermineerd, daarvoor alleen op geslachtsniveau. In de analyses worden ook alle tot op geslachtsniveau gedetermineerde individuen als Magallana gigas meegenomen. Vervolgens zijn biomassa ( $g$ ADW per $\mathrm{m}^{-2}$ ) en dichtheid (aantal individuen per $\mathrm{m}^{-2}$ ) berekend per monsterpunt.

\subsection{Analyses}

\subsubsection{Trendanalyses}

In dit rapport is er gekeken naar de ontwikkelingen (trends) in dichtheid en biomassa van het macrozoöbenthos in de tijd, ontwikkelingen van verschillende taxonomische groepen (i.e. phylum) en naar veranderingen in de verhoudingen tussen de wijzen van voedselopname door het macrozoöbenthos. Daarbij ligt de focus op de drie belangrijkste phyla in termen van biomassa en dichtheid: Mollusca, Arthropoda, Annelida. De volgende trofische groepen werden in het Grevelingenmeer aangetroffen: predator, omnivoor, herbivoor, suspension feeder, deposit en (sub)surface deposit feeder. Voor sommige soorten is de manier van voedselopname nog onbekend terwijl andere soorten verschillende manieren van voedselopname toepassen, afhankelijk van de situatie. In dit rapport wordt de nadruk gelegd op veranderingen in de patronen van voedselopname door deposit (bodemetende) en suspension (filtrerende) feeders. Ook is gekeken of trends verschillen 
per deelgebied en seizoen. In voorgaande rapporten (Schaub et al. 2002; Wetsteijn, 2011; Arcadis 2013) zijn de gegevens ook geanalyseerd per dieptestratum. In dit rapport wordt ervoor gekozen om de gegevens niet per dieptestratum te analyseren maar de (werkelijk gemeten) diepte te gebruiken als een continue variabele. Als onderdeel van het MWTL programma worden er sinds 1999 in het vooren najaar ook sediment monsters genomen in het oostelijke en westelijke deel van het Grevelingenmeer met als doel inzichten te krijgen in de ruimtelijk en temporele variatie van de sedimentsamenstelling. Sedimentsamenstelling is namelijk één van de omgevingsparameters die het voorkomen van bodemdieren kan bepalen (Ysebaert \& Herman 2003). In dit rapport worden twee sedimentkarakteristieken besproken die bepalend zijn voor bodemdieren: de mediane korrelgrootte en het slibgehalte.

Voor de trendanalyses is gekozen voor de detectie van niet-lineaire trends. Een GAMM (Generalised Additive Mixed Model) is toegepast op de waarnemingen van biomassa en dichtheid, gebruik makend van het statistische programma R (R Core Team, 2015) met de volgende bibliotheek: nlme (Pinheiro et al. 2018). Biomassa en dichtheid zijn beide tot de vierdemachtswortel getransformeerd om te voldoen aan de voorwaarden van het model (normaalverdeling en gelijke variantie). Deelgebied en seizoen zijn gebruikt als factor en diepte en jaar als smoother. Een smoother is een functie die belangrijke patronen en/of trends in de data probeert te ontdekken en welke kan variëren van een rechte lijn tot een interpolatie van alle datapunten. Een factor is in het model toegevoegd om te testen of de trend (smoother) verschilt per deelgebied en seizoen. Daarnaast is een random effect aan elk model toegevoegd om te corrigeren voor de ruimtelijk correlatie tussen de monsterpunten. Echter, voor de sedimentgegevens bleek geen correctie nodig te zijn voor de ruimtelijke correlatie tussen monsterpunten. Daarom zijn GAM (Generalised Additive Model) modellen toegepast op de waarnemingen van de mediane korrelgrootte als functie van de tijd en diepte. Omdat het slibgehalte uitgedrukt is in proporties en een groot aantal nullen bevat zijn deze gegevens niet gemodelleerd maar weergegeven in een boxplot.

Op basis van zeven modellen (Tabel 2) waar jaar, seizoen, diepte en deelgebied op verschillende wijze zijn meegenomen, is de keuze gemaakt (AIC, Akaike's Information Criterium) voor de configuratie die de meeste variatie in de gegevens verklaart.

Tabel 2. Verschillende modellen die zijn toegepast op de data.

$\begin{array}{ll}\text { Model } & \text { Verklarende variabele } \\ \text { Model_0 } & \text { Jaar + Diepte + Seizoen + Deelgebied } \\ \text { Model_1 } & \text { Jaar + Diepte + Seizoen } \times \text { Deelgebied } \\ \text { Model_2 } & \text { Jaar + Diepte } \times \text { Seizoen + Seizoen + Deelgebied } \\ \text { Model_3 } & \text { Jaar + Diepte } \times \text { Deelgebied + Seizoen + Deelgebied } \\ \text { Model_4 } & \text { Jaar + Diepte } \times \text { Seizoen_Deelgebied + Seizoen + Deelgebied } \\ \text { Model_5 } & \text { Jaar } \times \text { Seizoen + Diepte + Seizoen + Deelgebied } \\ \text { Model_6 } & \text { Jaar } \times \text { Deelgebied + Diepte + Seizoen + Deelgebied } \\ \text { Model_7 } & \text { Jaar } \times \text { Seizoen_Deelgebied + Diepte + Seizoen + Deelgebied }\end{array}$

\subsubsection{Multivariate analyse}

Tevens is gekozen om de dataset ook te analyseren door middel van 'Multidimensional Scaling', MDS (Legendre \& Legendre, 1998) waarmee de mate van similariteit van de voorkomende soorten tussen verschillende deelgebieden, dieptes en/of jaren zichtbaar gemaakt kan worden.

Vereenvoudigde weergave van soortensamenstellingsgegevens d.m.v. MDS analyse

Met een MDS-analyse is getracht om de informatie uit een kruistabel zoals een tabel van soorten dichtheden over monsterpunten vereenvoudigd weer te geven in een tweedimensionale grafiek. Voor de constructie van deze grafiek zijn de verschillen in de dichtheden van alle soorten tussen alle paren van monsterpunten uitgedrukt als een afstand berekend door middel van (bijvoorbeeld) de Bray-Curtis (BC) similariteitscoëfficiënt (Legendre \& Legendre, 1998). 


$$
S_{j k}=100 .\left\{1-\frac{\sum_{i=1}^{p}\left|d_{i j}-d_{i k}\right|}{\sum_{i=1}^{p}\left(d_{i j}+d_{i k}\right)}\right\} \quad \text { (Bray-Curtis (BC) similariteitscoëfficiënt) }
$$

$S_{j k}$, de BC coëfficiënt tussen monsters $j$ en $k$ is berekend op basis van de dichtheden van de aanwezige $i$ van 1 tot $p$ soorten in de verschillende monsters ( $d_{i j}$ en $d_{i k}$ zijn de dichtheden van soort $i$ respectievelijk in monsters $j$ en $k$ ). De waarde van de BC-coëfficiënt meet vervolgens de 'afstand' in soortensamenstelling tussen die monsters.

Voor deze berekening zijn de dichtheden getransformeerd d.m.v. een vierdemachtswortel transformatie $\left(d_{\text {transf }}=\left[\mathrm{N} / \mathrm{m}^{2}\right]^{0.25}\right)$ waarmee soorten met hoge én lage dichtheden een meer vergelijkbaar invloed hebben op de analyse: een vertienvoudiging in de waarnemingen $\left(\mathrm{N} / \mathrm{m}^{2}\right)$ vertaalt zich inderdaad tot slechts een verdubbeling $\left(10^{0.25} \approx 1,8\right)$ in de gegevens na de transformatie. $\mathrm{Na}$ de berekening van die coëfficiënten is op iteratieve wijze door de routine gezocht naar de plaatsing van de locaties op een grafiek met zo weinig mogelijk dimensies (idealiter 2 dimensies) waar de afstanden tussen de locaties zo goed mogelijk overeenkomt met de waarden van de BC coëfficiënten ${ }^{1}$. De kwaliteit van de representatie is gemeten door een stresswaarde $(<0,1$ : uitstekend; $<0,15$ : goed; $<0,2$ : redelijk). De MDS analyse is uitgevoerd door middel van het statische programma $\mathrm{R}$ (metaMDS () routine, bibliotheek: vegan (Oksanen et al. 2019)). Op gelijke wijze wordt de afstand tussen soorten berekend op basis van de dichtheden waargenomen op de verschillende locaties. Beiden de afstanden tussen de soorten én de afstanden tussen de monsters zijn uiteindelijk weergegeven op dezelfde MDS plot.

\section{Analyse van de relatie tussen patronen in soortensamenstelling en omgevingsfactoren}

- Relatie met de omgevingsfactoren is getoetst met de envfit() routine ( $R$, package vegan). De routine envfit berekent de correlatie $\left(r^{2}\right)$ tussen de ligging van de monsters in het ordinatievlak en de gradiënten in de omgevingsfactoren.

- Verschillen tussen groepen van monsters gevormd op basis van b.v. de geografische ligging, diepte, seizoen, jaar is getoetst door middel van de anosim() routine ( $R$, package vegan). Zoals bij de envfit routine is de verkregen $\mathrm{R}$-waarde getoetst door middel van permutaties tussen de monsters. Bij r-waarden groter dan 0.5 is er spraak van significante verschillen; lager dan 0.1 zijn de verschillen niet significant.

- Bijdrage van individuele taxa aan de gedetecteerde verschillen tussen de groepen van monsters is getoetst door middel van de simper() routine ( $R$, package vegan).

\section{Voorbereiding van de bodemdieren gegevens voor de analyse}

- Zeldzame soorten hebben een lage trefkans en kunnen daardoor niet kwantitatief bemonsterd worden; hun 'toevallige' aanwezigheid in een paar monsters zorgt bovendien voor een 'kunstmatige' verhoging van de afstand tussen deze monsters en de rest van de dataset. Ten gunste van de resultaten is het vaak aanbevolen om een selectie te maken van de soorten die meegenomen worden in de multivariate analyse. Clarke \& Warwick (2001) bevelen de soorten die in minder dan $3 \%$ van de monsters aanwezig zijn niet mee te nemen. Voor de huidige dataset zou een dergelijke uitsluiting een afname betekenen van 307 tot slechts 61 taxa (Figuur 5). Om het informatieverlies minimaal te houden, is er hier gekozen voor $1 \%$ als minimale voorkomens-frequentie voor het deelnemen van de taxa aan de analyse waarmee 96 taxa in de selectie over blijven.

\footnotetext{
${ }^{1}$ t.g.v. de beeldvorming: het gebruik van een afstandstabel tussen de Nederlandse steden als input bij een MDS levert een kaart van de Nederlandse steden op.
} 


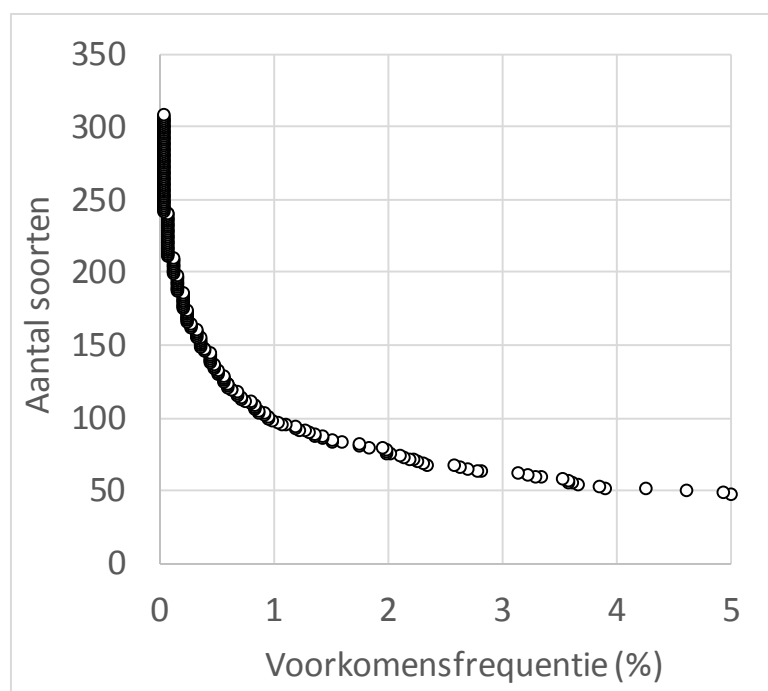

Figuur 5. Aantal soorten in de dataset als functie van hun voorkomensfrequentie.

- Monsters. Binnen elke diepte-stratum zijn er (per deelgebied, seizoen, jaar) 10 monsters genomen. Voor de huidige studie waar gezocht wordt naar majeure temporele trends is de ruimtelijke heterogeniteit binnen elk dieptestratum niet relevant. Daardoor zijn er voor elke niveau van jaar, seizoen, deelgebied, dieptestratum de 10 monsters samengevoegd (gemiddeld) tot een monster. De huidige analyse beslaat vervolgens 96 taxa en 252 monsters.

- Studieperioden. Naast de trendanalyses zijn de periodes (voor 2001, 2001-2007 en na 2007, zie Figuur 6) met elkaar vergeleken d.m.v. een ANOSIM.

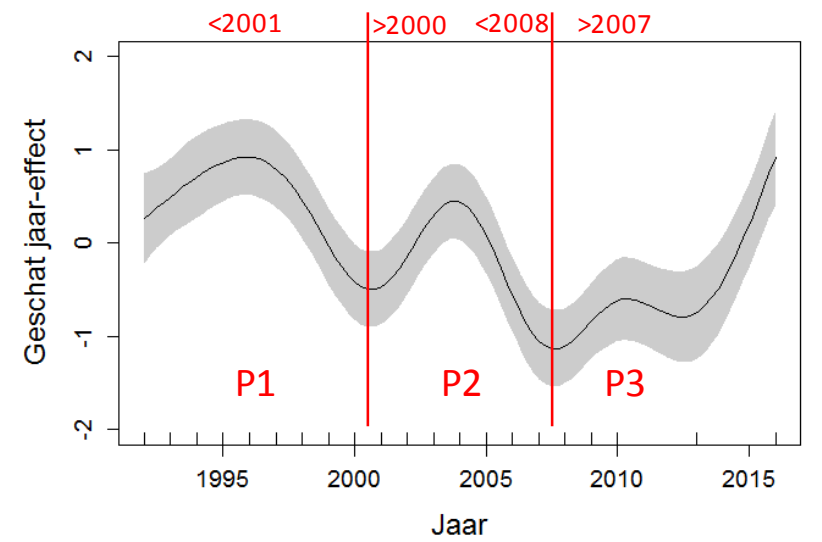

Figuur 6. Perioden P1, P2 en P3 gebruikt voor het toetsen van het temporele effect op de bodemdieren gemeenschappen weergegeven samen met de trends in totale dichtheid zoals beschreven in hoofdstuk 4.3. 


\section{Resultaten}

\subsection{Samenstelling macrozoöbenthos}

Twaalf verschillende phyla komen voor in de volledige MWTL-dataset (1992-2016) van het macrozoöbenthos in het Grevelingenmeer (Tabel 3 en illustraties in Figuur 7). De Mollusca met gemiddeld $82.9 \%$ van de totale biomassa $\left(\mathrm{g} / \mathrm{m}^{2}\right)$ vormt de belangrijkste groep van het macrozoöbenthos. Annelida en Arthropoda zijn met respectievelijk $9.1 \%$ en $3.8 \%$ beduidend minder belangrijk. De overige phyla nemen slechts een bescheiden plaats in $(<1.7 \%$ per phyla) (Figuur 8 , Figuur 10). De gemiddelde ( \pm SD) biomassa van het macrozoöbenthos (1992-2013) bedraagt $52.2 \pm$ $19.5 \mathrm{~g}$ per $\mathrm{m}^{2}$. Worden de verschillende phyla in dichtheden (aantallen $/ \mathrm{m}^{2}$ ) uitgedrukt dan vormt het phylum Annelida (wormen) met gemiddeld $61.6 \%$ de belangrijkste groep, gevolgd door Arthropoda (19.6\%) en Mollusca (17.5\%). De overige phyla vertegenwoordigen minder dan 1\% per phyla (Figuur 9, Figuur 11). De gemiddelde dichtheid van het macrozoöbenthos (1992-2016) bedraagt $4527 \pm$ 1626 individuen per $\mathrm{m}^{2}$.

Tabel 3. Bijdrage per phylum (\%) aan de totale biomassa (1992-2013) en dichtheid (1992-2016).

\begin{tabular}{|l|l|cc|}
\hline Phylum & NL namen & Biomassa (\%) & Dichtheid (\%) \\
\hline Annelida & Wormen & 9.1 & 61.6 \\
Arthropoda & Geleedpotigen & 3.8 & 19.6 \\
Bryozoa & Mosdieren & 0.0 & 0.0 \\
Chordata & Gewervelden & 1.7 & 0.3 \\
Cnidaria & Neteldieren & 1.0 & 0.4 \\
Echinodermata & Stekelhuidigen & 1.1 & 0.0 \\
Mollusca & Weekdieren & 82.9 & 17.5 \\
Nemertea & Snoerwormen & 0.0 & 0.4 \\
Ochrophyta & Bruinwieren & 0.0 & 0.0 \\
Phoronida & Hoefijzerwormen & 0.0 & 0.0 \\
Platyhelminthes & Platwormen & 0.0 & 0.0 \\
Porifera & Sponsdieren & 0.3 & 0.0 \\
\hline
\end{tabular}

Worden gegevens naar aantallen (dichtheid) met onderscheid van voedselgildes ingedeeld dan vormen de bodemetende organismen ((sub)surface deposit feeders en deposit feeders samen) met $47 \%$ de grootste groep. De filtrerende organismen (suspension feeders) vertegenwoordigen een kleiner deel, namelijk $16 \%$. Qua biomassa is suspension feeding met $83 \%$ de belangrijkste wijze van voedselvergaring. 

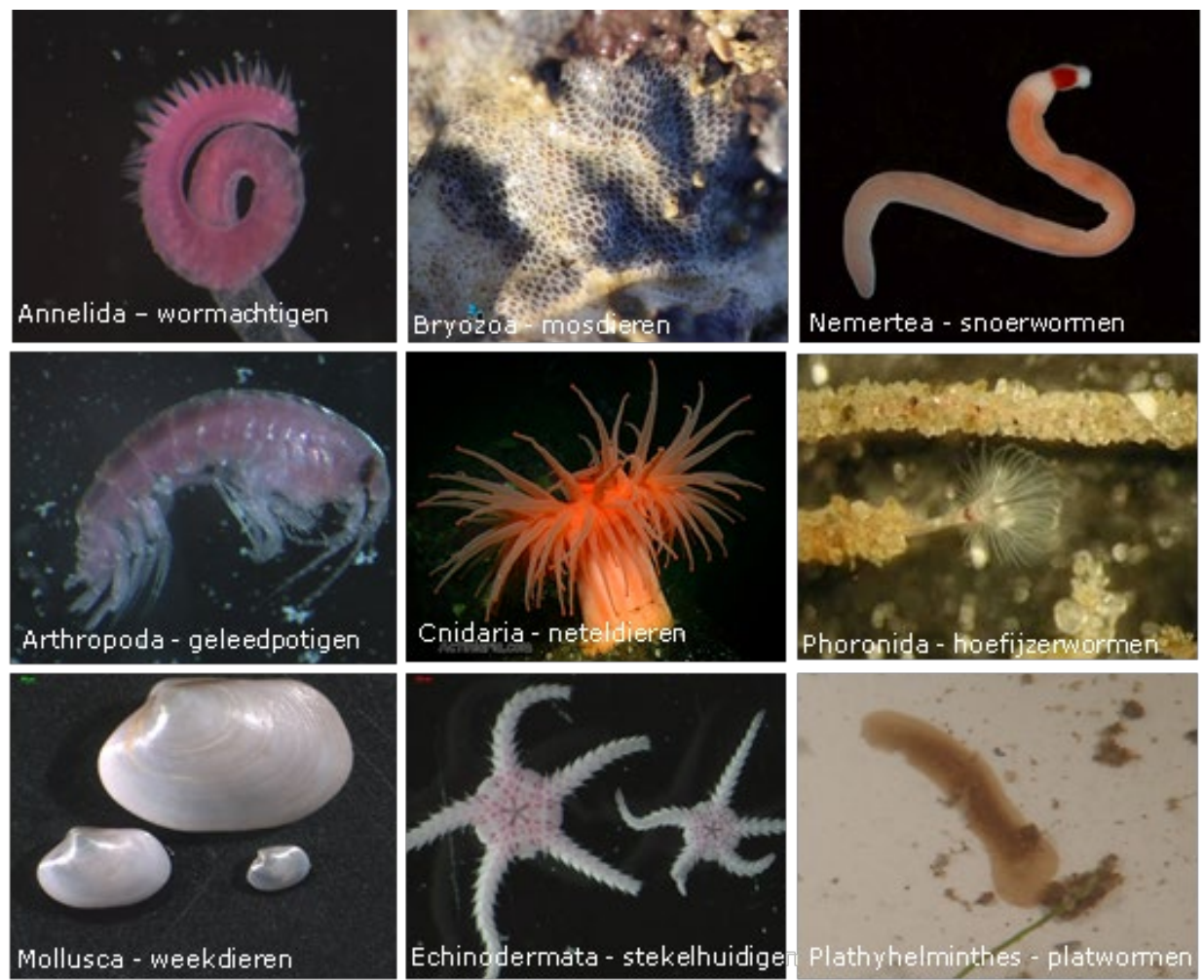

Figuur 7. Voorbeelden van een aantal phyla: Annelida, Bryozoa, Nemertea (foto: www.dnr.sc.gov/marine), Arthropoda, Cnidaria (www.actinaria.com), Phoronida (foto: Peter Grobe via Flikr), Mollusca, Echinodermata en Plathyhelminthes (foto's van Wageningen Marine Research tenzij anders vermeld).

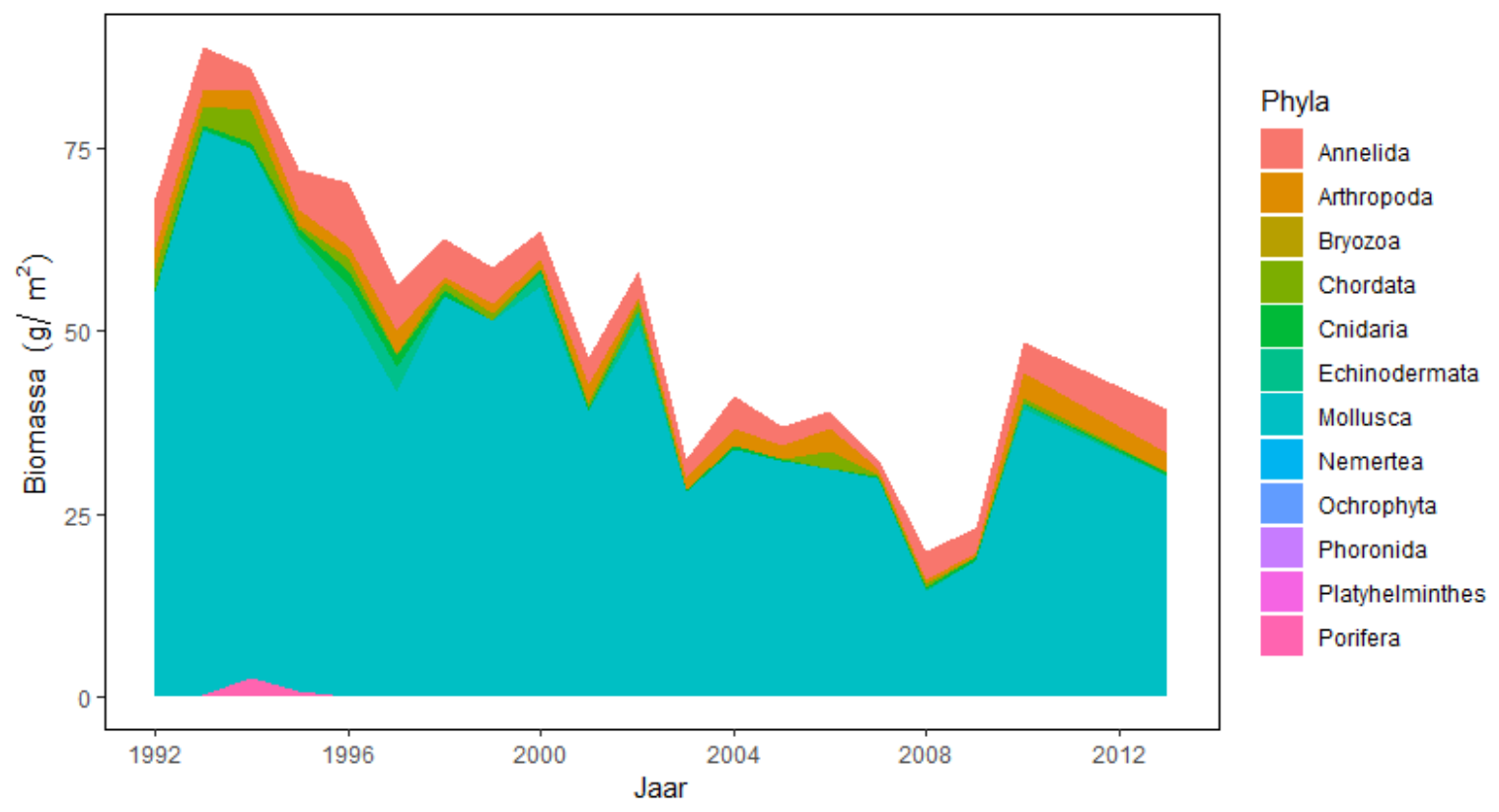

Figuur 8. De ontwikkeling van biomassa $\left(\mathrm{g} / \mathrm{m}^{2}\right)$ van het macrozoöbenthos in het Grevelingenmeer op het phylum niveau in de periode 1992 tot 2013.

Als er naar veranderingen van biomassa op phylumniveau wordt gekeken is een sterke achteruitgang waarneembaar in Mollusca tussen 1993 en 2008 (Figuur 8, Tabel 8). In deze periode fluctueert de biomassa ook sterk tussen jaren en neemt in bepaalde jaren toe (bv. 2002, 2010, 2013). Er is ook een lichte daling waarneembaar in Annelida en Arthropoda maar deze is niet zo sterk als voor Mollusca. Phyla die maar een klein deel van de biomassa vertegenwoordigen $(<2 \%)$ nemen in het algemeen af (bv. Chordata, Cnidaria) of blijven gelijk (bv. Nemertea) (Tabel 8). Als er naar de dichtheden wordt gekeken, is een duidelijke achteruitgang te zien in Mollusca en in mindere mate in Annelida (Figuur 9). Arthropoda neemt echter in dichtheden toe in de afgelopen 21 jaar. Net als biomassa fluctueren ook dichtheden sterk met hoge pieken in 1996 en 2004, vooral in Annelida (Tabel 9). 


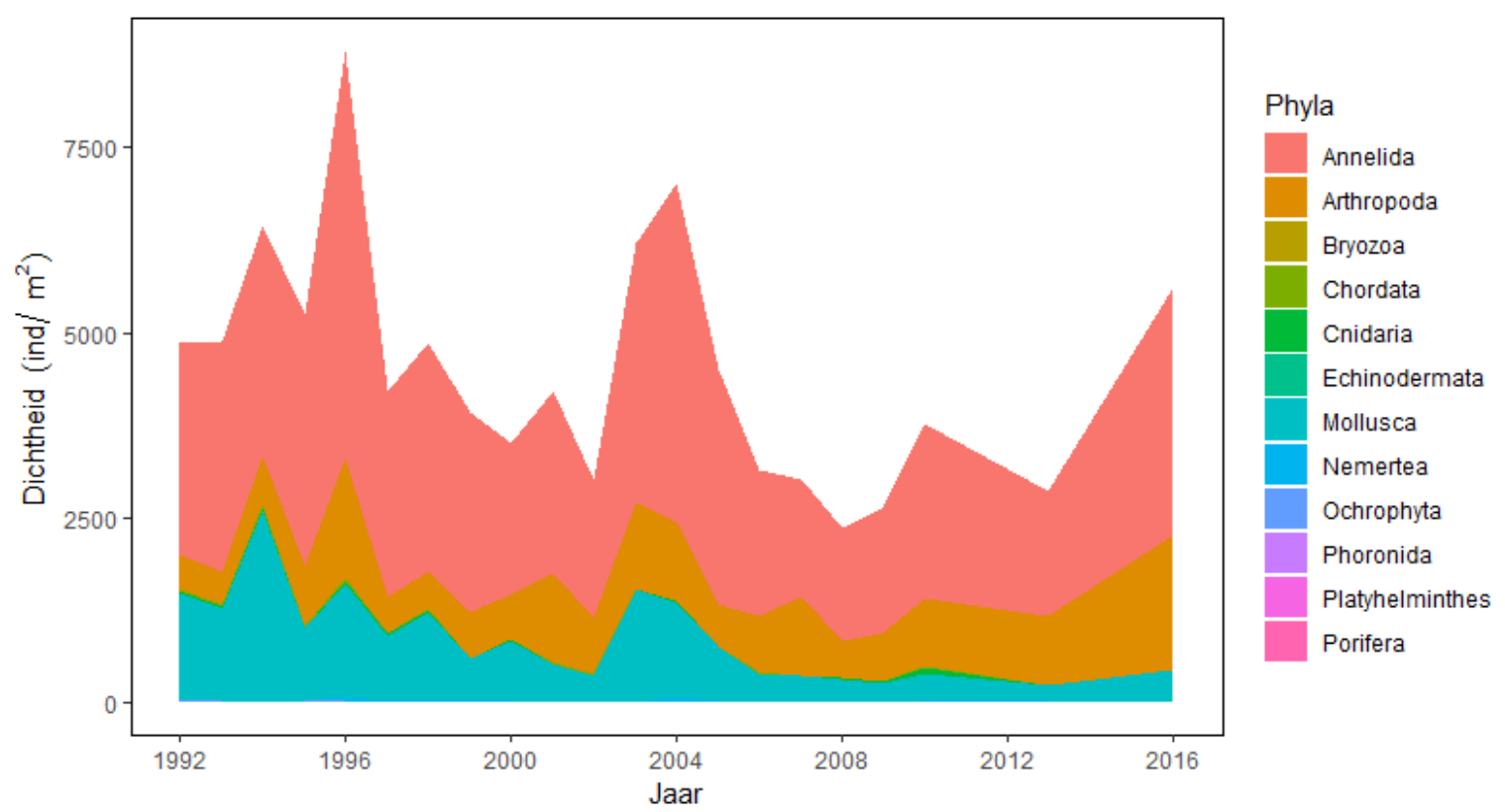

Figuur 9. De ontwikkeling van dichtheden (ind $/ \mathrm{m}^{2}$ ) van het macrozoöbenthos in het Grevelingenmeer op phylum niveau in de periode 1992 tot 2013.

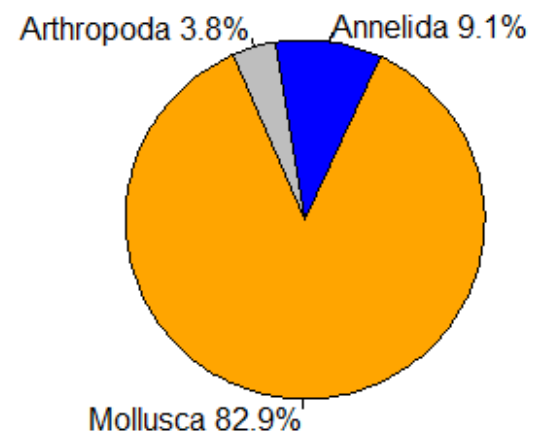

Figuur 10. Phyla die in biomassa (\%) de dominante groep vormen van het macrozoöbenthos in de periode 1992 tot 2013.

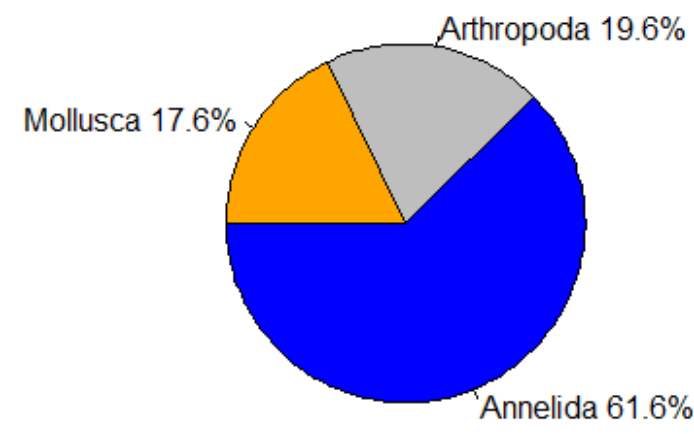

Figuur 11. Phyla die in dichtheden (\%) de dominante groep vormen van het macrozoöbenthos in de periode 1992 tot 2016. 


\subsection{Soortenrijkdom en dominante soorten}

In het macrozoöbenthos zijn er 307 verschillende taxa onderscheiden in de periode 1992 tot 2016. Een deel van deze taxa is niet op soort gebracht (zie paragraaf 3.1). In het deel dat wel op soort gebracht is, worden 171 soorten onderscheiden. Tussen 1992 en 2010 werden gemiddeld 92 taxa per jaar onderscheiden. In 2013 en 2016 lagen deze aantallen hoger, namelijk 127 en 198 taxa, respectievelijk (Figuur 13). Sinds 2013 is de bemonsterde oppervlakte in de twee diepere strata fors toegenomen wat tot een toename van het aantal waargenomen soorten kan leiden. Daarnaast is het analyseprotocol sinds 2013 aangepast (Leewis et al. 2015) en is er van analyse labo veranderd. Dit maakt dat de jaren 2013 en 2016 niet direct vergelijkbaar zijn met de jaren voordien en er niet kan geconcludeerd worden dat de soortenrijkdom in het Grevelingenmeer is toegenomen. Dit dient nader onderzocht te worden.

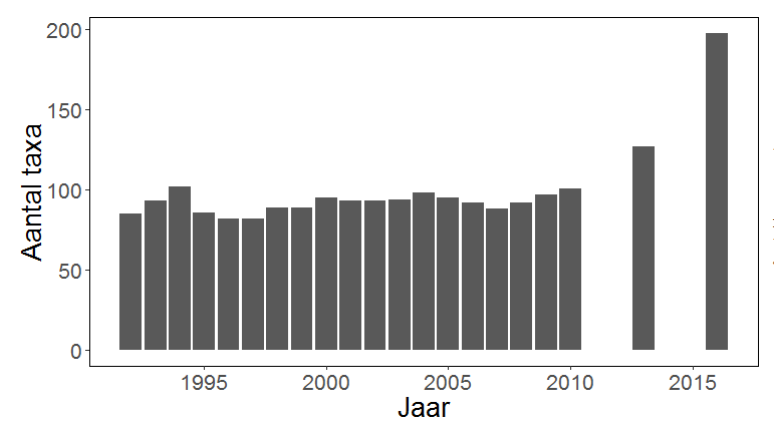

Figuur 13. Aantal onderscheiden taxa per jaar in de periode 1992 tot 2016.

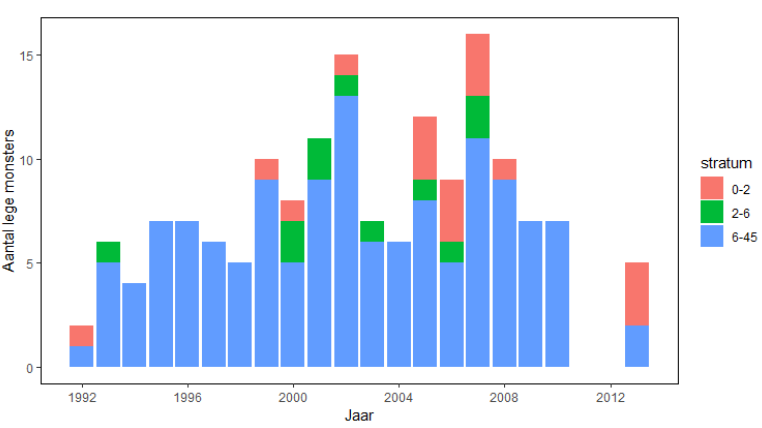

Figuur 12. Aantal lege monsters per jaar en diepte stratum.

Tussen 1992 en 2016 zijn er in totaal 2460 bodemmonsters genomen. De meest voorkomende soorten/taxa waren de wormen (Oligochaeta, Polydora sp., Scoloplos armiger, Platynereis dumerilii, Heteromastus filiformis, Alitta succinea, Spio martinensis, Capitella spp., Arenicola spp.), het muiltje (Crepidula fornicata), vlokreeften (Microdeutopus gryllotalpa, Monocorophium insidiosum), het tweetandschelpje (Kurtiella bidentata) en de korfschelp (Corbula gibba) (Figuur 14, Tabel 4). In 160 van de 2460 monsters zijn geen levende organismen aangetroffen (Figuur 12). Deze monsters lagen voornamelijk op grotere diepte (gemiddeld $-10.3 \mathrm{~m}$ t.o.v. NAP). Er is een toename in het aantal lege monsters zichtbaar tot 2002 waarna het aantal lege monsters fluctueert. In latere jaren worden er ook lege monsters gevonden in de ondiepe zone. In 2016 werden geen lege monsters aangetroffen. Dit zal in een vervolgstudie nader onderzocht worden.

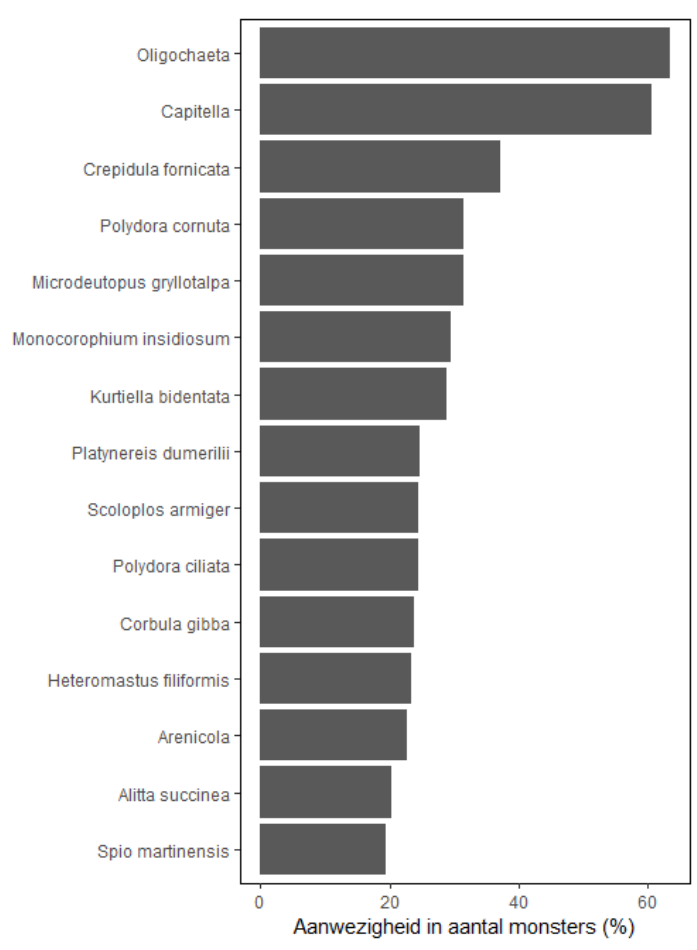

Figuur 14. De meest voorkomende soorten (\%) in monsters genomen in de periode 1992-2016. 
De biomassa wordt gedomineerd door weekdiersoorten zoals Crepidula fornicata, Venerupis corrugata, Mytilus edulis en Ostrea edulis (Figuur 16). Het muiltje (Crepidula fornicata) is verreweg de meest dominante soort in de bodemmonsters, zowel in biomassa (Figuur 16) als in dichtheid (Figuur 17). Het muiltje (Crepidula fornicata) draagt gemiddeld $58.4 \%$ bij aan de gemiddelde totale biomassa over de volledige studieperiode, maar de soort vertoont een significante afname van $56.9 \mathrm{~g} / \mathrm{m}^{2}$ in 1993 naar $10.5 \mathrm{~g} / \mathrm{m}^{2}$ in 2013 (Figuur 15).
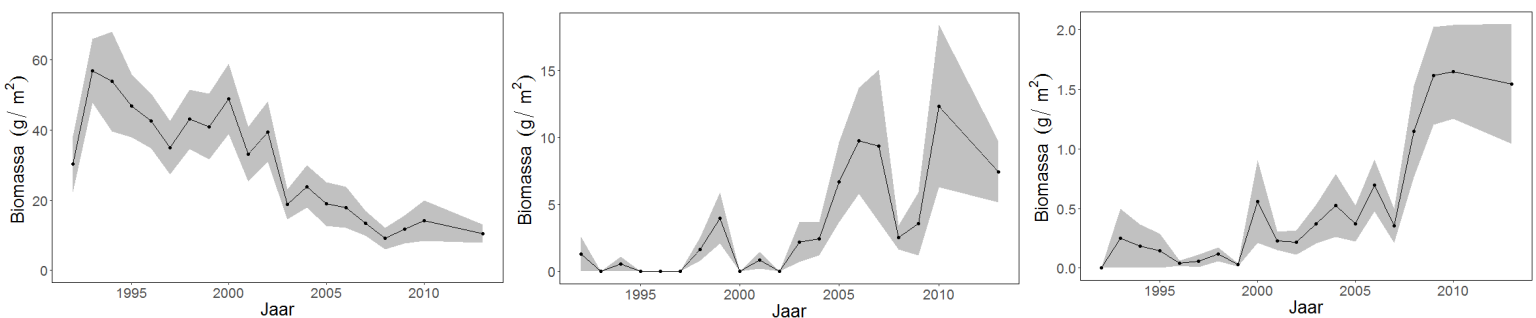

Figuur 15. Gemiddelde biomassa $\left(\mathrm{g} / \mathrm{m}^{2}\right)$ per jaar van Crepidula fornicata (links), Magallana gigas (midden) en Arenicola (rechts) in de periode 1992-2013. Het grijze gebied geeft de standaard error weer.

De meeste soorten die domineren op het gebied van biomassa (Figuur 16) blijven gelijk of nemen af gedurende de studieperiode met uitzondering van de Japanse oester (Magallana gigas) en de wadpier Arenicola welke beide toenemen (Figuur 15, Tabel 4). Door overbevissing, een strenge winter en het optreden van oesterziekten was het oesterbestand van de inheemse Zeeuwse platte oester (Ostrea edulis) gedecimeerd in de jaren 1960 en gingen oesterkwekers op zoek naar alternatieven. De Japanse oester (M. gigas) werd gezien als een nieuwe mogelijkheid en de soort werd op verschillende plekken in Europa (waaronder Yerseke, Zeeland) geïntroduceerd. De oester bleek zich goed in onze wateren te kunnen voortplanten en koloniseerde in rap tempo de Zeeuwse wateren en de Waddenzee. Tot op heden neemt zowel de biomassa als dichtheid van de Japanse oester nog steeds toe (Figuur 15), met hoge dichtheidspieken in 2003 en 2010. Ondanks de afwezigheid van grote variatie in de biomassa van de platte oester tussen 1995 en 2010, gaat de soort er per dichtheid op achteruit. Ook de mossel (Mytilus edulis) neemt in zowel biomassa als dichtheid af, alhoewel aantallen en biomassa weer wat zijn toegenomen in 2010 en 2013. Naast weekdieren vertegenwoordigen ook zakpijpen (Ascidiacea), zeesterren (Asterias rubens) en zeeanemonen (Actiniaria) een relatief groot deel van de totale biomassa (Figuur 16).
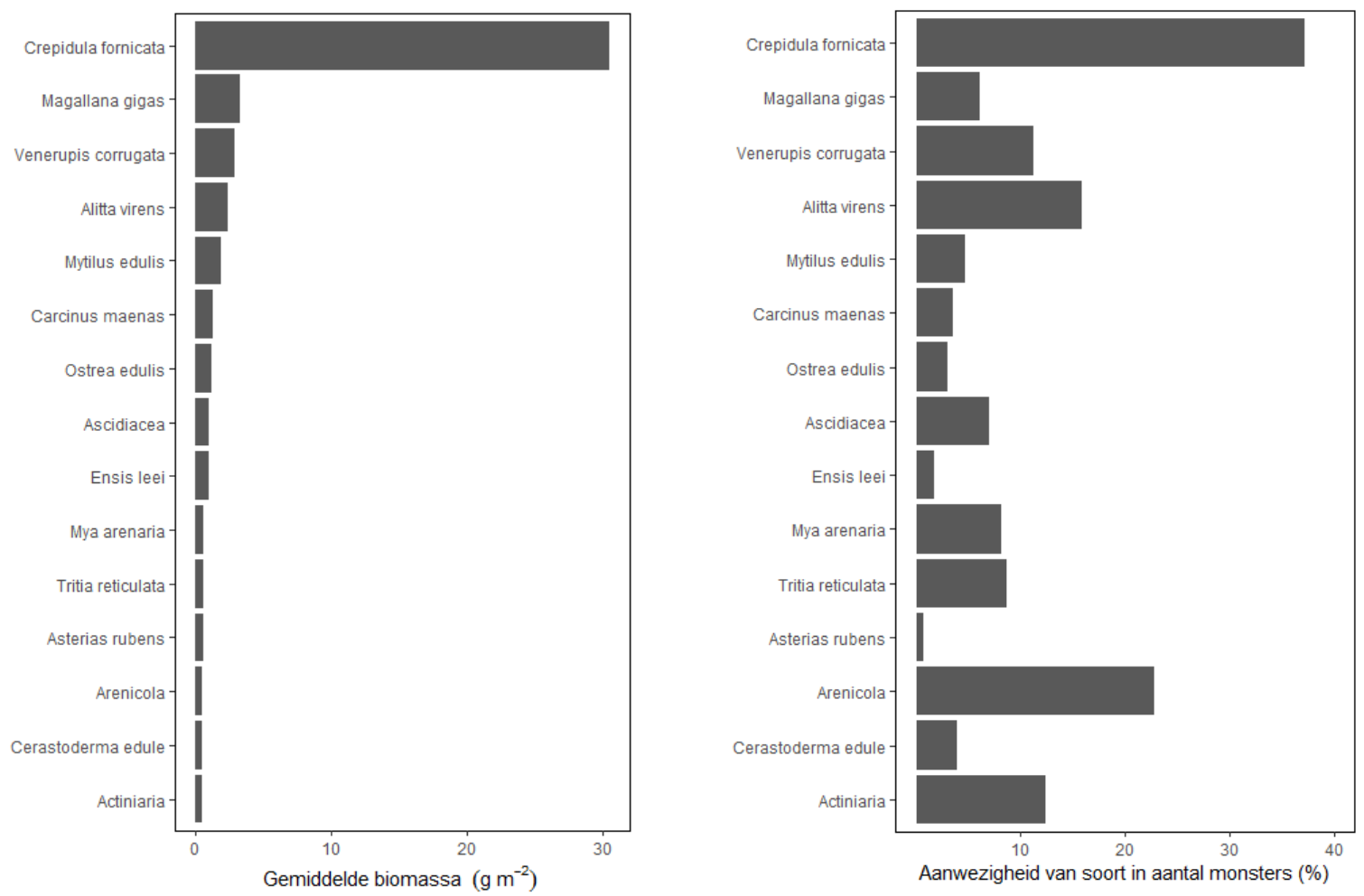

Figuur 16. Gemiddelde biomassa ( $\mathrm{g} \mathrm{m}^{-2}$, links) van de 15 meest dominante soorten en het aantal keer dat deze soorten zijn aangetroffen in een monster (\%, rechts) in de periode 1992-2013. De gemiddelde biomassa van

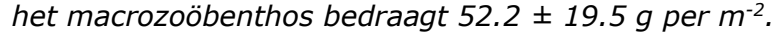


Tabel 4. Voorbeelden van een aantal dominante soorten: Crepidula fornicata, Magallana gigas, Venerupis corrugata, Arenicola spp., Capitella (foto: www.anemoon.org), Alitta virens, Capitella spp. (foto:

www.marinespecies.org), Mytilus edulis, Corbula gibba (foto: www.naturalhistory.museumwales.ac.uk), Monocorophium insidiosum (foto: Bathyporeia via Flickr), Oligochaeta (foto: www.nederlandsesoorten. $n$ l).

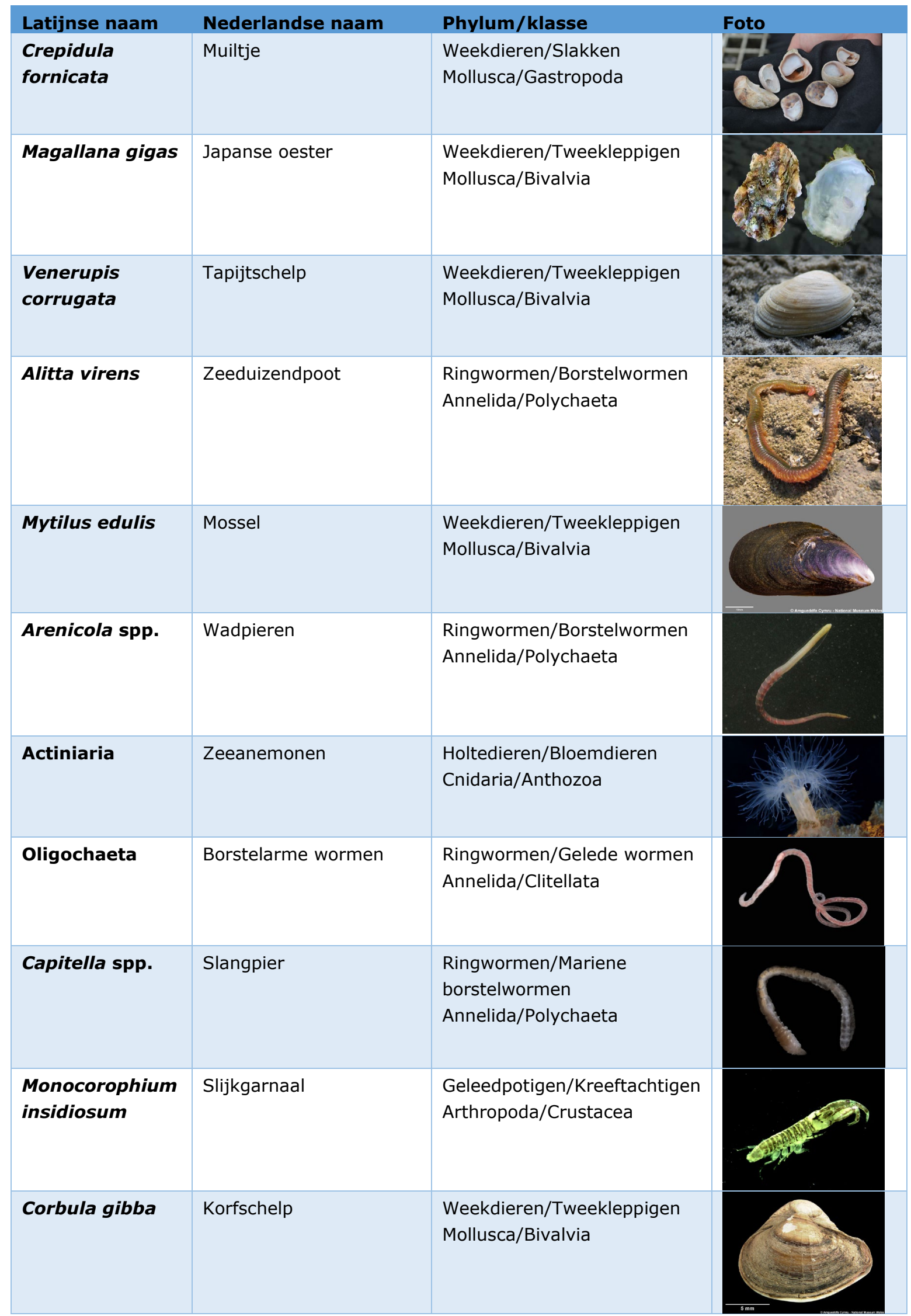


Ook een aantal soorten wormen vormen een belangrijke bijdrage aan de totale biomassa, Alitta virens (zager) en Arenicola spp. (wadpier) welke sinds 2000 een stijging in biomassa laat zien (Figuur 15).

De dichtheid wordt gedomineerd door wormen (o.a. Oligochaeta, Capitella, Polydora), geleedpotigen (Monocorophium insidiosum, Microdeutopus gryllotalpa) en weekdieren (Crepidula fornicata, Corbula gibba, Kurtiella bidentata) (Figuur 17, Tabel 4).
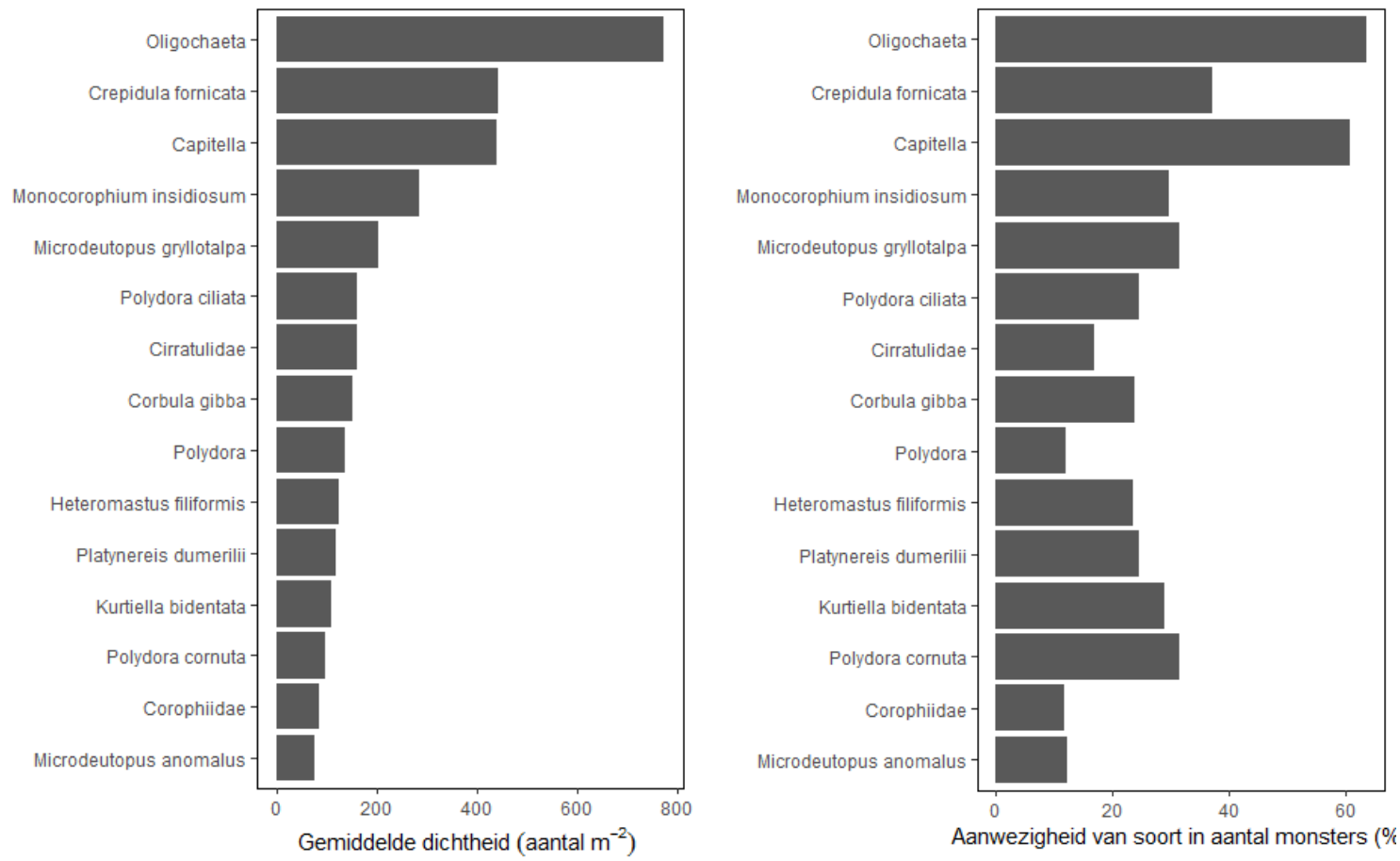

Figuur 17. Gemiddelde dichtheid (aantal $\mathrm{m}^{2}$, links) van de 15 meest dominante soorten en het aantal keer dat deze soorten zijn aangetroffen in een monster (\%, rechts) in de periode 1992-2016. De gemiddelde dichtheid van het macrozoöbenthos is $4527 \pm 1626$ aantallen per $\mathrm{m}^{-2}$.

De meeste soorten nemen af (o.a. Crepidula fornicata, Oligochaete, Kurtiella bidentata, Cirratulidae) of blijven gelijk (o.a. Corbula gibba) in aantallen tussen 1992 en 2016, met uitzondering van Capitella welke enigszins in aantallen toeneemt tussen 1997 en 2016 (Figuur 18). In tegenstelling tot het plaatje op basis van de biomassa spelen commerciële soorten zoals Mytilus edulis (mossel) en Ostrea edulis (platte oester) een minder belangrijke rol in de totale dichtheid. Een andere commerciële soort (maar waar in het Grevelingenmeer niet wordt op gevist) die buiten de top 15 valt is de kokkel (Cerastoderma edule). De dichtheid van de kokkel is afgenomen van $44 \mathrm{ind} / \mathrm{m}^{2}$ in 1992 tot $10 \mathrm{ind} / \mathrm{m}^{2}$ in 2016 terwijl de biomassa vrij constant is gebleven. Het Grevelingenmeer schijnt voor deze drie commerciële soorten dus minder geschikt te zijn geworden.
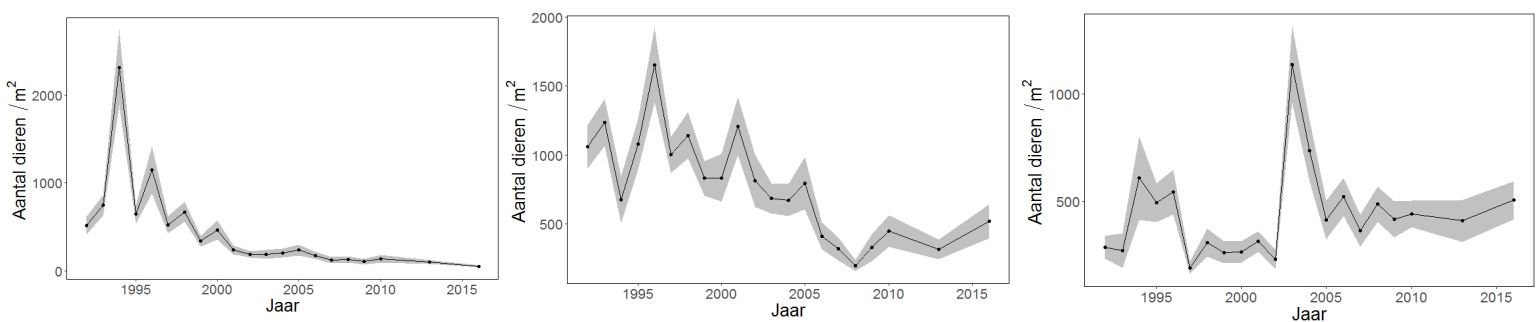

Figuur 18. Gemiddelde dichtheid (ind $/ \mathrm{m}^{2}$ ) per jaar van Crepidula fornicata (links), Oligochaeta (midden) en Capitella spp. (rechts) in de periode 1992-2016. Het grijze gebied geeft de standaard error weer. 
Exoten

Wijnhoven \& Hummel (2009) hebben een uitgebreide historische analyse uitgevoerd van exoten in de Zeeuwse wateren gebruik makend van de MTWL-data aangevuld met historische data van het NIOOCEME over benthische gemeenschappen (1960-2008). Wetsteijn (2011) heeft, gebruik makend van Wijnhoven \& Hummel (2009), een samenvatting gegeven van de exoten specifiek voor het Grevelingenmeer. Hieruit bleek dat 18 (vermeende) exoten soorten zijn aangetroffen waarvan vier soorten als invasief worden gezien welke zich succesvol hebben gevestigd in het Grevelingenmeer: het muiltje (Crepidula fornicata, Figuur 19) in de jaren 60, de Japanse oester (Magallana gigas, Figuur 20) in 1991, de Amerikaanse zwaardschede (Ensis leei, Figuur 21) in 1990 en de strandgaper (Mya arenaria, Figuur 22) in de jaren 60 (Wijnhoven \& Hummel 2009). Hieronder wordt weergegeven hoe deze soorten zich over de tijd hebben ontwikkeld. Het MWTL bemonsteringsprotocol is niet gericht op het monitoren van Japanse Oester banken of riffen. Vaak is het juist lastig monsteren in dit soort habitats, omdat er niet voldoende sediment bemonsterd wordt en vaak meerdere pogingen nodig zijn. Het analyseren van de volledige boxcore sinds 2013 vergroot mogelijk de trefkans van deze soort. Ondanks dit zien we een duidelijke toename van deze soort in het Grevelingenmeer sinds 2005.
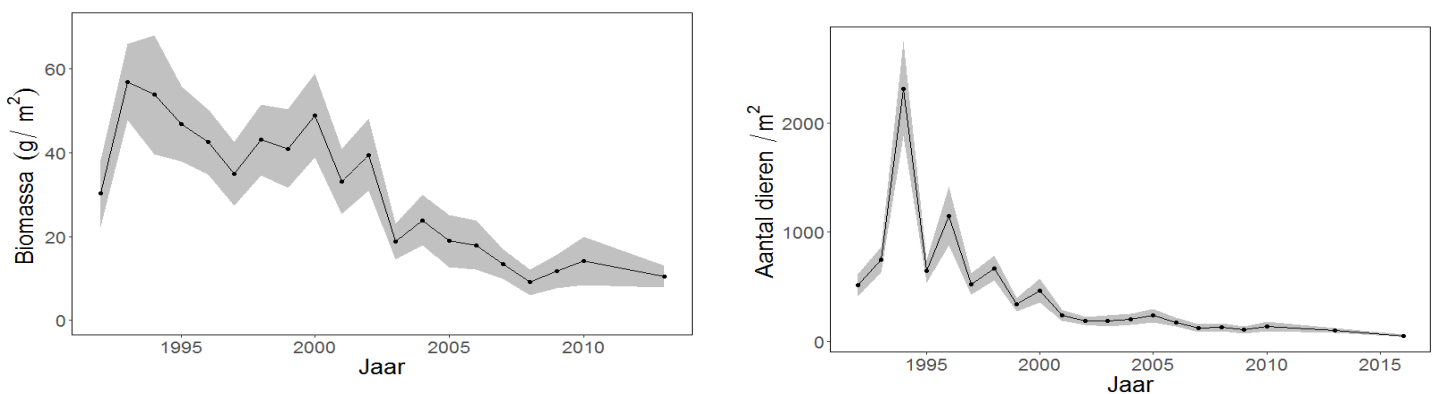

Figuur 19. De gemiddelde biomassa (links, in $\mathrm{g} / \mathrm{m}^{2}$ ) en dichtheid (rechts, ind $/ \mathrm{m}^{2}$ ) per jaar van Crepidula fornicata.
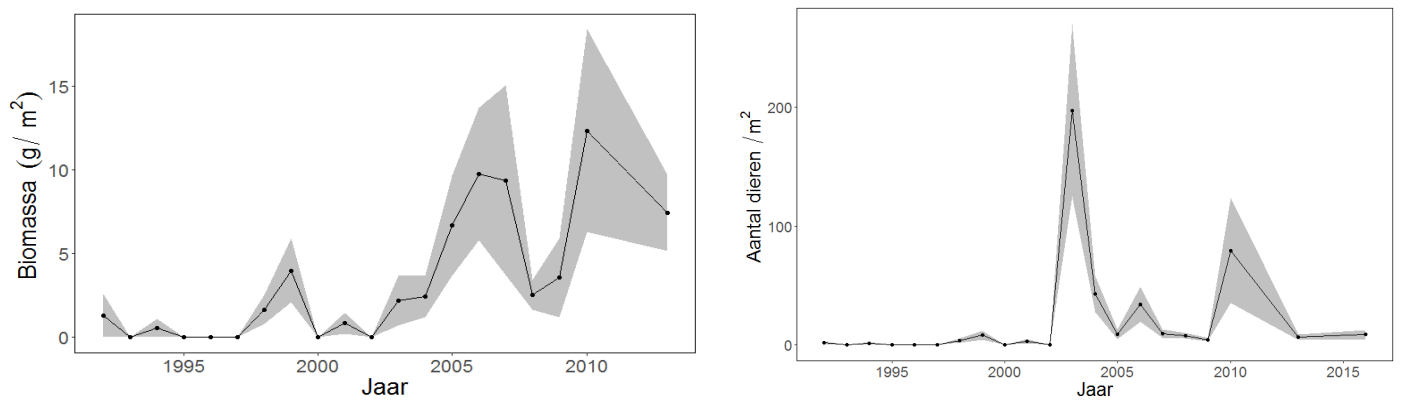

Figuur 20. De gemiddelde biomassa (links, in $\mathrm{g} / \mathrm{m}^{2}$ ) en dichtheid (rechts, ind $/ \mathrm{m}^{2}$ ) per jaar van Magallana gigas.
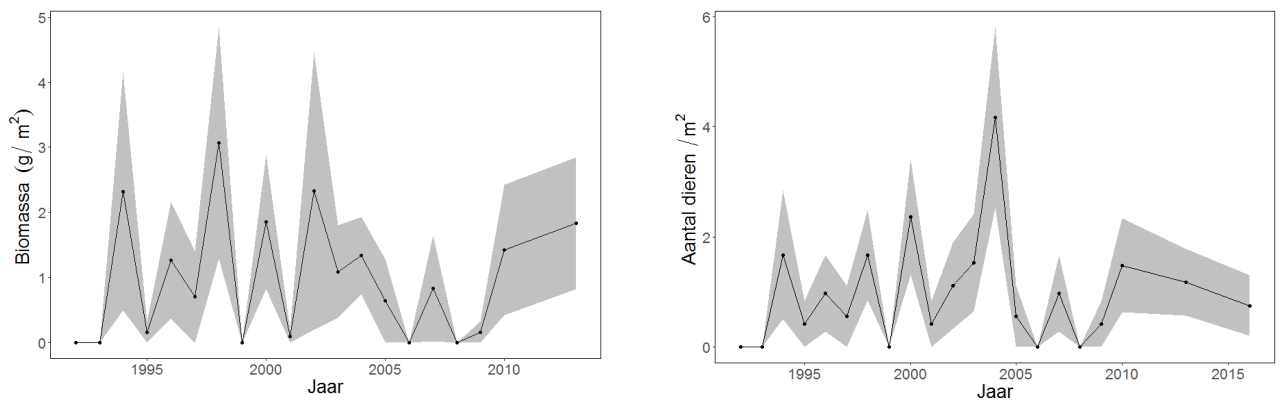

Figuur 21. De gemiddelde biomassa (links, in $\mathrm{g} / \mathrm{m}^{2}$ ) en dichtheid (rechts, ind $/ \mathrm{m}^{2}$ ) per jaar van Ensis leei. 

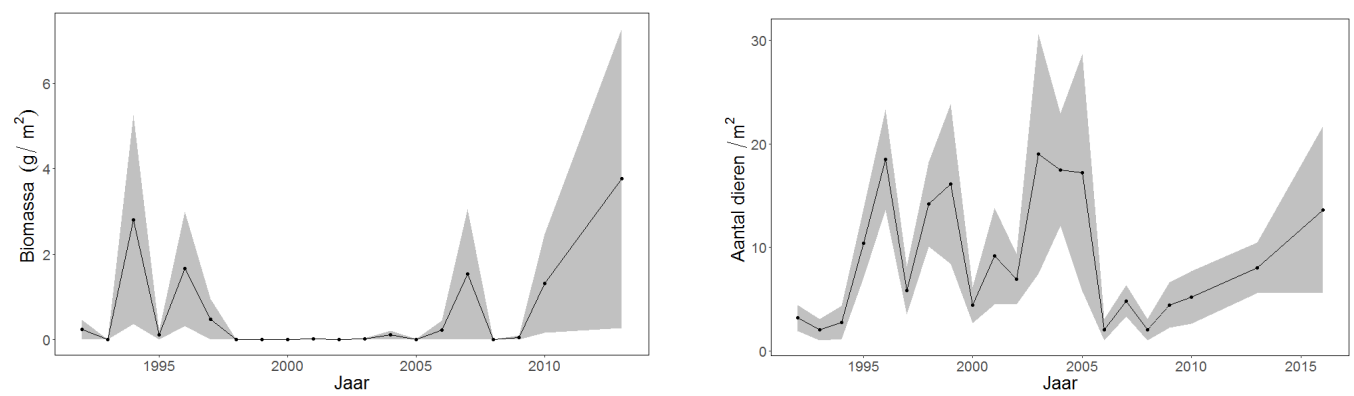

Figuur 22. De gemiddelde biomassa (links, in $\mathrm{g} / \mathrm{m}^{2}$ ) en dichtheid (rechts, ind $/ \mathrm{m}^{2}$ ) per jaar van Mya arenaria.

Van deze vier soorten neemt één soort af (het muiltje), één soort toe (Japanse oester) en blijven de overige twee soorten ongeveer gelijk. Alle vier de soorten zijn weekdieren en vormen een belangrijke bijdrage aan de totale biomassa. Alleen het muiltje speelt ook een belangrijke rol in de totale dichtheid. Sinds de laatste rapportage door Wetsteijn (2011) zijn er nieuwe exoten (o.a. de zeepok Balanus improvisus) bijgekomen in het Grevelingenmeer (Leewis et al. 2015) maar deze dragen geen of nog geen grote bijdrage aan de totale biomassa of dichtheid aangezien geen nieuwe exoten voorkomen in de lijst met meest dominante soorten (Figuur 16, Figuur 17). 


\subsection{Trends in tijd}

De tabel geeft een overzicht van de modellen die uiteindelijk de meeste variatie verklaarden voor de biomassa en dichtheid (totaal en van de verschillende phyla en voedselgildes) en sedimenttype (mediane korrelgrootte). Als de vorm van de trend in de tijd (Jaar) of over diepte verschilt per deelgebied of seizoen (interactie) wordt dat aangegeven in de eerste twee kolommen (Jaar, Diepte). Is de rij leeg dan verschilt de vorm van de trend niet per deelgebied of seizoen. De kolommen 'Deelgebied' en 'Seizoen geven aan of de gemiddelde biomassa en dichtheden verschillen tussen het oostelijke en westelijke deel van het Grevelingenmeer of tussen het voor- en najaar. Deze tabel wordt in de aparte paragrafen hieronder verder uitgewerkt.

Tabel 5. Overzicht van de modellen welke de meeste variatie in de data verklaarden. De kolommen Jaar en Diepte geven aan of de vorm van de trend verschilt tussen deelgebied en seizoen. De kolommen Deelgebied en Seizoen geven aan of de gemiddelde biomassa en dichtheden verschillen tussen het westelijke en oostelijke deel van het Grevelingenmeer en het voor- en najaar. $\Delta=$ hoger, lege kolom = geen verschil.

\begin{tabular}{|c|c|c|c|c|}
\hline & Jaar & Diepte & Deelgebied & Seizoen \\
\hline Totale biomassa & & & $\Delta$ west & $\Delta$ voorjaar \\
\hline Biomassa zonder $C$. fornicata & deelgebied & & $\Delta$ west & $\Delta$ voorjaar \\
\hline Mollusca & & & & \\
\hline Annelida & deelgebied & & $\Delta$ west & $\Delta$ voorjaar \\
\hline Arthropoda & seizoen & & & $\Delta$ voorjaar \\
\hline Totale dichtheid & & seizoen & $\Delta$ west & $\Delta$ voorjaar \\
\hline Mollusca & seizoen & & $\Delta$ west & \\
\hline Annelida & & seizoen & $\Delta$ west & $\Delta$ voorjaar \\
\hline Arthropoda & seizoen & & & \\
\hline \multicolumn{5}{|l|}{ Bodemetende organismen } \\
\hline dichtheid & & seizoen & $\Delta$ west & $\Delta$ voorjaar \\
\hline biomassa & deelgebied & & $\Delta$ west & $\Delta$ voorjaar \\
\hline \multicolumn{5}{|l|}{ Filtrerende organismen } \\
\hline dichtheid & seizoen & & $\Delta$ west & $\Delta$ najaar \\
\hline biomassa & deelgebied & & & \\
\hline Mediane korrelgrootte & & deelgebied & $\Delta$ west & \\
\hline
\end{tabular}

\subsubsection{Biomassa}

\subsubsection{Algemeen}

Uit de GAMM-analyses blijkt dat Model_0 (Tabel 2), waar de verklarende variabelen individueel meegenomen zijn zonder onderlinge interactie, de meeste variatie verklaart in biomassa. De linker grafiek in Figuur 23 geeft de gemiddelde biomassa $\left(\mathrm{g} / \mathrm{m}^{2}\right)$ per jaar weer in de periode 1992-2013 terwijl de rechter grafiek de trend weergeeft welke is berekend door het model (Model_0) op basis van de vierdemachtswortel-getransformeerde biomassa ( $y$-as). Het GAMM model geeft aan dat jaar ( $x$-as) een significant effect heeft op de biomassa $(p<0.001)$ (Figuur $23-R$ ) wat betekent dat er een significante trend waarneembaar is van biomassa in de tijd. Het model geeft aan dat biomassa significant afneemt tussen 1995 en 2008 en vervolgens weer enigszins toeneemt in 2010 en 2013 . De vorm van de trend verschilt niet per seizoen of deelgebied (afwezigheid van interactie tussen de verklarende variabelen). Wel is de biomassa gemiddeld iets hoger in het voorjaar dan in het najaar $(p=0.030)$ en gemiddeld hoger in het westelijke deel dan in het oostelijke deel $(p=0.010)$ (Figuur 8) van het Grevelingenmeer. Het verschil in biomassa is groter tussen deelgebieden dan tussen seizoenen.

Naast het modelleren van de totale biomassa $(0-46 \mathrm{~m})$ in de tijd, is ook gekeken of biomassa zich vergelijkbaar ontwikkeld binnen elk diepte stratum. De analyses zijn niet opgenomen in dit rapport maar de resultaten laten zien dat biomassa significant afneemt $(p<0.001)$ (zoals in Figuur 23) in de tijd in zowel de ondiepe delen (0-2 $\mathrm{m}$ en 2-6 m) als de diepere delen $(6-45 \mathrm{~m})$ van het Grevelingenmeer. 

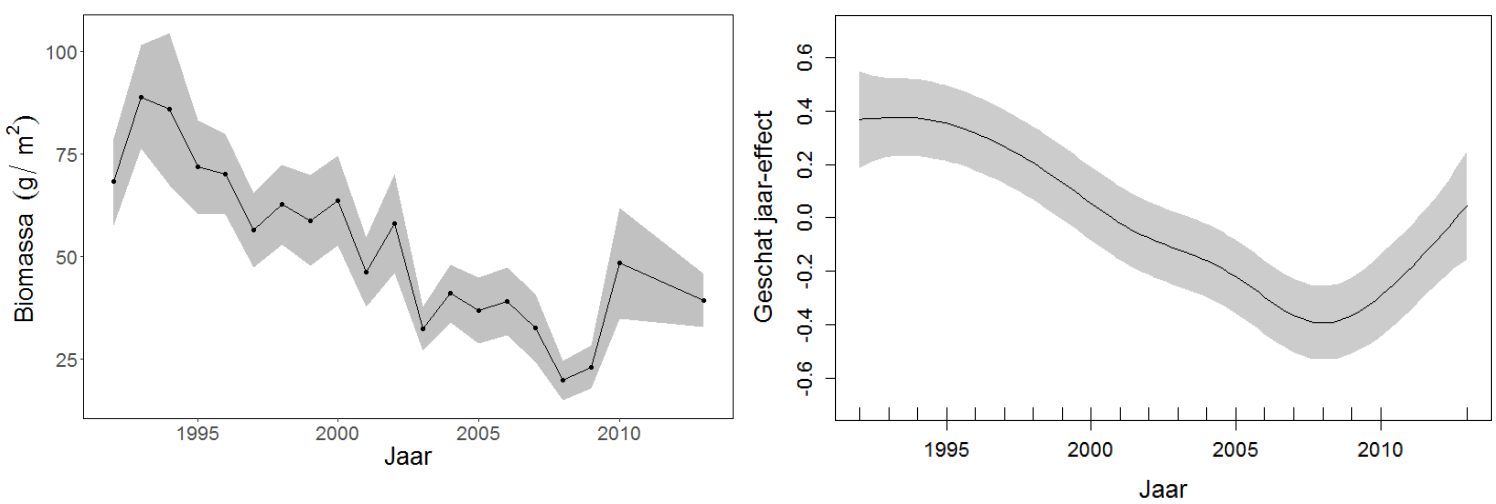

Figuur 23. Links - Grafiek van de gemiddelde totale biomassa $\left(\mathrm{g} / \mathrm{m}^{2}\right)$ per jaar in de periode 1992 tot 2013. Het grijze gebied geeft de standaard error weer. Rechts - Het geschatte effect van jaar op de vierdemachtswortel-getransformeerde totale biomassa $\left(\mathrm{g} / \mathrm{m}^{2}\right)$ in de periode 1992 tot 2013. De getrokken lijn geeft het resultaat van het GAMM model (Model_0) over alle data. Het grijze gebied geeft het 95\%betrouwbaarheidsinterval weer.

Het GAMM model geeft ook aan dat waterdiepte ( $x$-as) een significant effect heeft op de biomassa ( $y$ as) $(p<0.001)$. In de ondiepe vooroever is de biomassa laag maar neemt significant toe tot een diepte van ongeveer $6 \mathrm{~m}$. Vanaf $6 \mathrm{~m}$ onder NAP neemt de biomassa weer significant af tot ongeveer $15 \mathrm{~m}$ waar het betrouwbaarheidsinterval toeneemt door het geringe aantal monsters dat genomen is op deze diepte (Figuur 24).

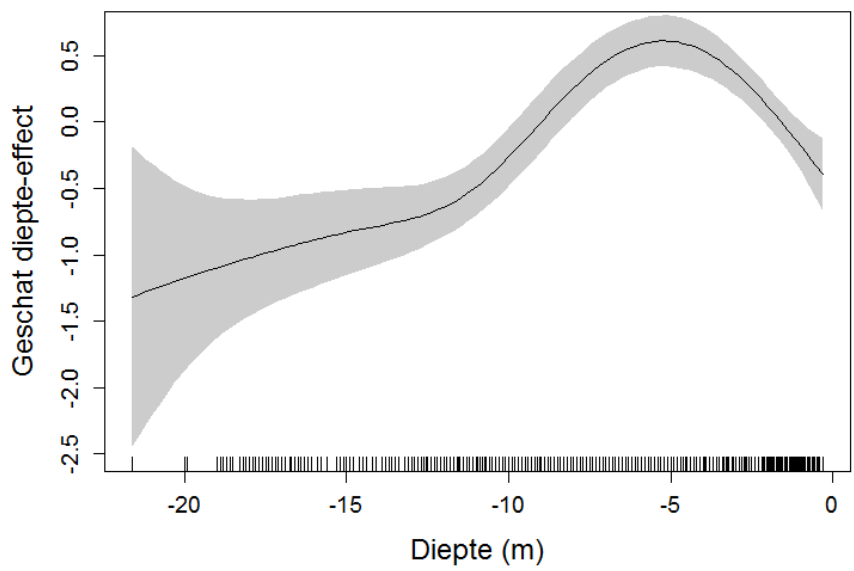

Figuur 24. Het geschatte effect van diepte (m, t.o.v. NAP) op de vierdemachtswortelgetransformeerde totale biomassa $\left(\mathrm{g} / \mathrm{m}^{2}\right)$. De getrokken lijn geeft het resultaat van het GAMM model (Model_0) weer over alle data. Het grijze gebied geeft het 95\%betrouwbaarheidsinterval weer.

Het GAMM-model analyseert de relatie tussen biomassa en diepte in de periode 1992-2013. De studieperiode is ook opgedeeld in twee (voor- en na 1999) en vier perioden (5-6 jaar intervallen) waarna gekeken is of deze relatie veranderde of verschoof in de tijd. De analyses zijn niet opgenomen in dit rapport maar de resultaten laten zien dat de optimale biomassa blijft liggen tussen de 4-6 m onder NAP met een significante daling naar diepere en ondiepere delen zoals ook waarneembaar in Figuur 24.

\subsubsection{Biomassa zonder Crepidula fornicata}

De Gastropode Crepidula fornicata (het muiltje) komt van oorsprong niet in het Grevelingenmeer voor en is waarschijnlijk samen met oesters geïmporteerd vanuit America. In de jaren 60 van de vorige eeuw werd de soort in alle grote bekkens van de Zeeuwse delta (Grevelingen, Oosterschelde) aangetroffen en is sindsdien sterk toegenomen (Wijnhoven \& Hummel 2009). Het muiltje vertegenwoordigd een gemiddelde biomassa van $30.5 \mathrm{~g} / \mathrm{m}^{2}$ terwijl de gemiddelde biomassa van het overige macrozoöbenthos, zonder deze dominante soort dus, $21.7 \mathrm{~g} / \mathrm{m}^{2}$ bedraagt. Er is daarom ook onderzocht hoe de biomassa van het overige macrozoöbenthos, zonder $C$. fornicata, zich ontwikkelt (Figuur 25). 


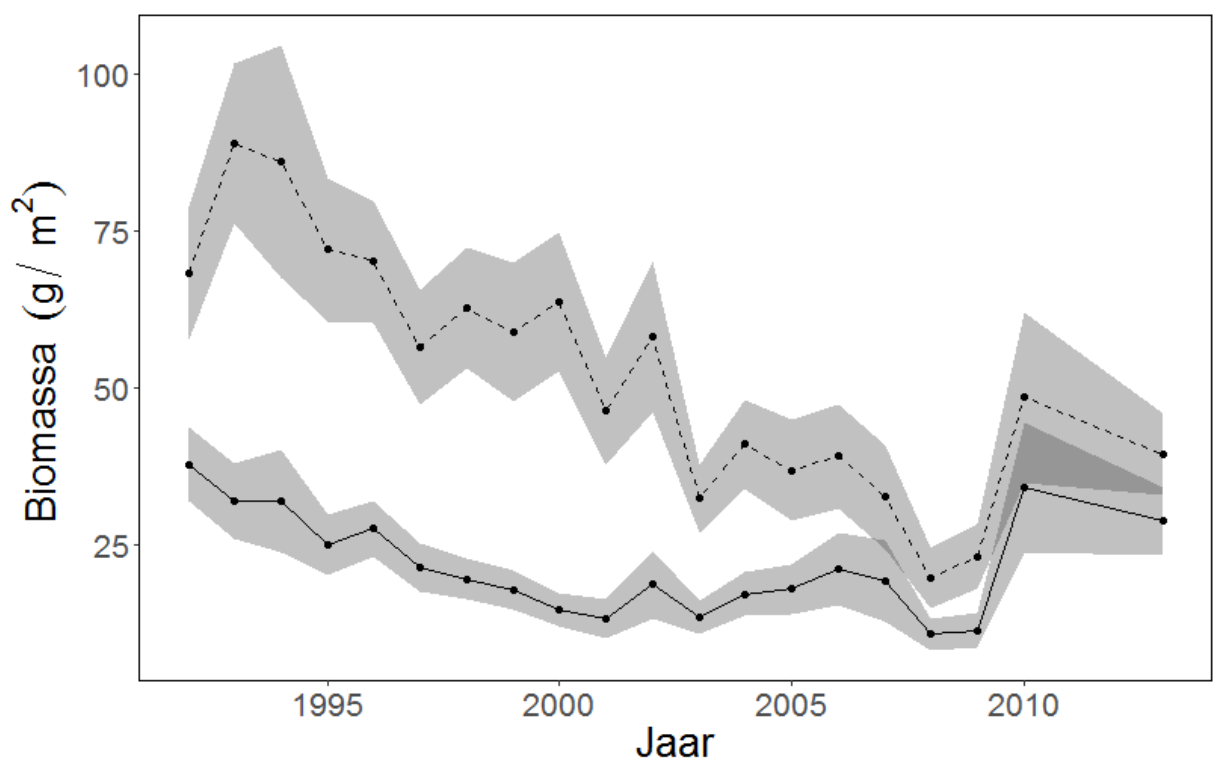

Figuur 25. De stippellijn vertegenwoordigt de totale biomassa $\left(\mathrm{g} / \mathrm{m}^{2}\right)$ zoals weergegeven in paragraaf 4.3.1.1, terwijl de vaste lijn de biomassa $\left(\mathrm{g} / \mathrm{m}^{2}\right)$ weergeeft zonder Crepidula fornicata voor de periode 19922013. Het grijze gebied geeft voor beide lijnen de standard error weer.

Uit de GAMM-analyse blijkt dat Model_6 (Tabel 2), waar het jaar effect varieert met het deelgebied de meeste variatie in de vierdemachtswortel-getransformeerde biomassa zonder $C$. fornicata verklaart. Het GAMM-model toont significante trends $(p<0.001)$ van biomassa in de tijd in beide deelgebieden (Figuur 26). Beide trends zijn op dezelfde schaal geplot waardoor het verschil tussen deelgebieden direct kan worden vergeleken. In het westelijk deel is vanaf 1992 een significant sterk dalende trend te zien in biomassa tot ongeveer 2008 waarna de biomassa weer toeneemt in 2010 en 2013. De trend is vergelijkbaar met die van de algemene biomassa (Figuur 23), wat aangeeft dat de aanwezigheid van $C$. fornicata de algemene trend niet beïnvloedt in het westelijk deel van het Grevelingenmeer. In
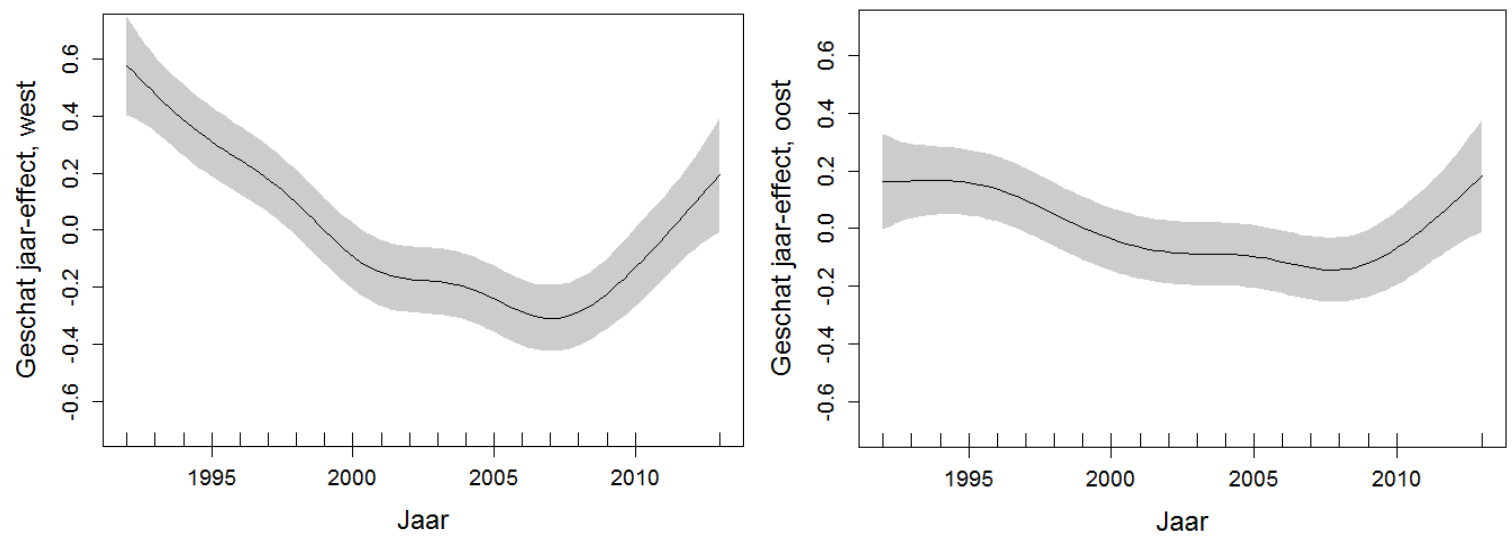

Figuur 26. Het geschatte effect van jaar op de vierdemachtswortel-getransformeerde biomassa $\left(\mathrm{g} / \mathrm{m}^{2}\right) \mathrm{zonder}$ Crepidula fornicata in het westelijk (links) en oostelijk (rechts) deel van het Grevelingenmeer in de periode 1992-2013. De getrokken lijn geeft het resultaat van het GAMM model (Model_6) over alle data. Het grijze gebied geeft het 95\%-betrouwbaarheidsinterval weer.

het oostelijk deel is deze dalende trend een stuk minder sterk wat suggereert dat de ontwikkeling in de biomassa van $C$. fornicata afwijkt af van alle andere soorten. Daarnaast is de biomassa gemiddeld hoger $(p<0.001)$ in het westelijk deel in vergelijking met het oostelijk deel. Alhoewel de vorm van de trend in het voor- en najaar gelijk blijft, is de biomassa gemiddeld hoger in het voorjaar. Het verschil in biomassa is wel groter tussen deelgebieden dan tussen seizoenen.

Het GAMM-model geeft ook aan dat waterdiepte ( $x$-as) een significant effect heeft op de biomassa ( $y$ as) $(p<0.001)$. In de ondiepe vooroever is de biomassa laag maar neemt significant toe tot een diepte van ongeveer 4 meter onder NAP. Vanaf 4 meter onder NAP neemt de biomassa weer significant af tot 
ongeveer $15 \mathrm{~m}$ waar het betrouwbaarheidsinterval toeneemt door het geringe aantal monsters dat genomen zijn op deze diepte (Figuur 27). Wanneer het diepte effect wordt vergeleken tussen de totale biomassa en de biomassa zonder Crepidula fornicata (Figuur 24, Figuur 27) is te zien dat door de aanwezigheid van $C$. fornicata er een sterkere relatie ontstaat tussen biomassa en diepte waarbij biomassa significant toeneemt van 0 tot 4-5 m diepte en vervolgens sterk afneemt.

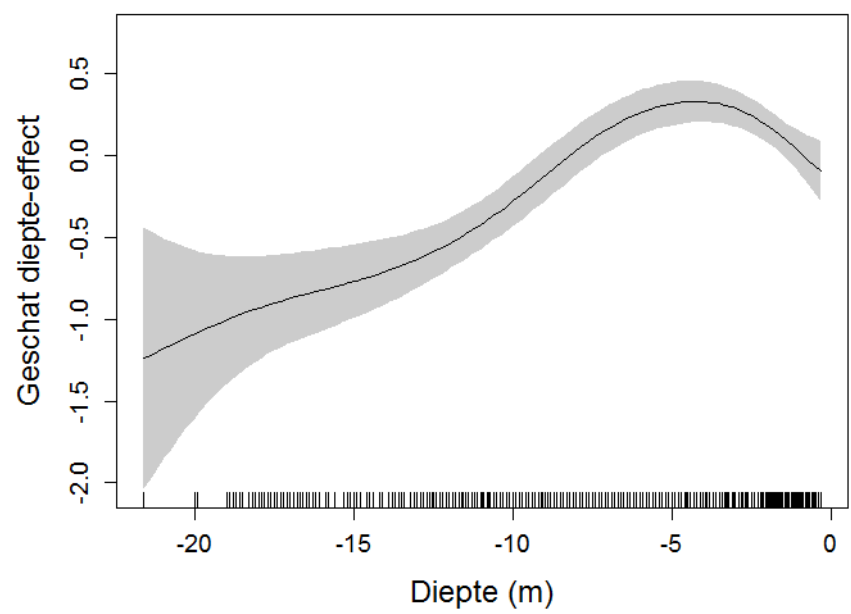

Figuur 27. Het geschatte effect van diepte $(m$, t.o.v. NAP) op de vierdemachtswortelgetransformeerde biomassa $\left(\mathrm{g} / \mathrm{m}^{2}\right)$ zonder $\mathrm{C}$. fornicata. De getrokken lijn geeft het resultaat van het GAMM model (Model_6) over alle data. Het grijze gebied geeft het $95 \%$ betrouwbaarheidsinterval weer.

\subsubsection{Phylum Mollusca}

Uit de GAMM-analyse blijkt dat Model_0 (Tabel 2), waar de verklarende variabelen individueel meegenomen zijn zonder onderlinge interactie, de meeste variatie verklaart voor de vierdemachtswortel-getransformeerde biomassa van Mollusca. Het GAMM-model geeft aan dat jaar ( $x$ as) een significant effect heeft op de biomassa $(p<0.001)$ (Figuur 28 - rechts) waarbij biomassa significant afneemt tussen 1993 en 2008 en vervolgens weer toeneemt in 2013. De vorm van de trend en de gemiddelde biomassa verschillen niet per deelgebied en/of seizoen ( $p>0.050)$.
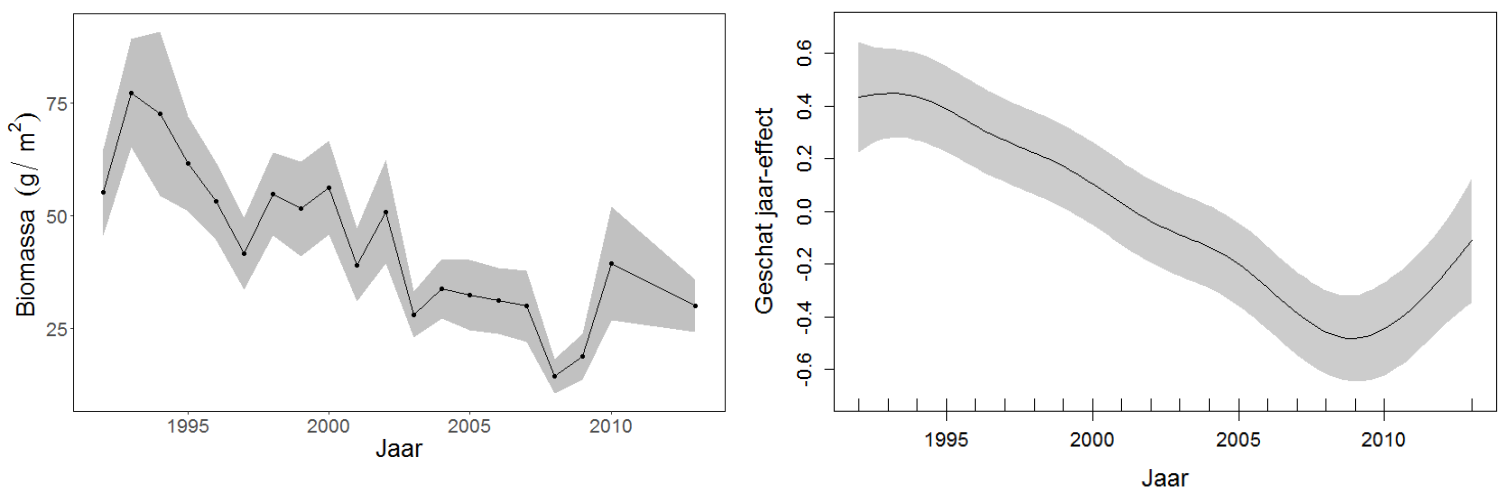

Figuur 28. Links - Grafiek van de gemiddelde biomassa $\left(\mathrm{g} / \mathrm{m}^{2}\right)$ van Mollusca per jaar in de periode 1992 tot 2013. Het grijze gebied geeft de standard error weer. Rechts - Het geschatte effect van jaar op de vierdemachtswortel-getransformeerde biomassa $\left(\mathrm{g} / \mathrm{m}^{2}\right)$ van Mollusca in de periode 1992-2013. De getrokken lijn geeft het resultaat van het GAMM model (Model_0) over alle data. Het grijze gebied geeft het 95\%betrouwbaarheidsinterval weer.

De biomassa binnen het phylum Mollusca fluctueert sterk tussen jaren (Figuur 28 - links). De pieken in 1993, 1994, 1998, 2000 en 2002 worden veroorzaakt door het muiltje (Crepidula fornicata) dat met

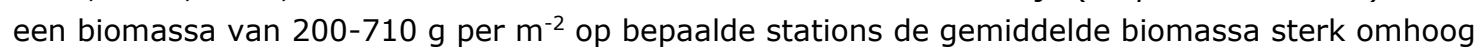
haalt. De stijging in biomassa in 2010 wordt veroorzaakt door een combinatie van soorten met hoge biomassawaarden op bepaalde stations, waaronder het muiltje $\left(250-500 \mathrm{~g} / \mathrm{m}^{2}\right)$, de Japanse oester $\left(500 \mathrm{~g} / \mathrm{m}^{2}\right)$ en de mossel $\left(800 \mathrm{~g} / \mathrm{m}^{2}\right)$ (Mytilus edulis).

Het GAMM-model geeft ook aan dat waterdiepte $(x-a s)$ een significant effect $(p<0.001)$ heeft op de biomassa (y-as) (Figuur 29): In de ondiepe vooroever is de biomassa laag maar neemt significant toe 
tot een diepte van ongeveer 5 meter onder NAP. Vanaf 5 meter diepte neemt de biomassa weer significant af tot ongeveer $15 \mathrm{~m}$ waar het betrouwbaarheidsinterval toeneemt door het geringe aantal monsters dat genomen zijn op deze diepte (Figuur 29).

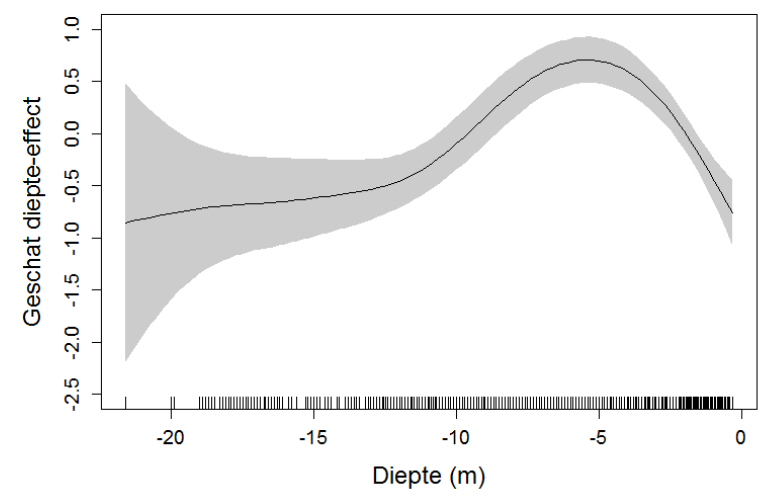

Figuur 29. Het geschatte effect van diepte ( $m$, t.o.v. NAP) op de vierdemachtswortel-getransformeerde biomassa $\left(\mathrm{g} / \mathrm{m}^{2}\right)$ van Mollusca. De getrokken lijn geeft het resultaat van het GAMM model (Model_0) over alle data. Het grijze gebied geeft het 95\%-betrouwbaarheidsinterval weer.

\subsubsection{Phylum Annelida}

Uit de GAMM-analyse blijkt dat Model_6 (Tabel 2), waar het jaar effect varieert met het deelgebied, de meeste variatie in biomassa van Annelida verklaart. Het GAMM-model toont significante trends $(p<0.001)$ van biomassa in de tijd in beide deelgebieden. Figuur 31 geeft de gemiddelde biomassa $\left(\mathrm{g} / \mathrm{m}^{2}\right)$ per jaar weer in de periode 1992-2013 terwijl Figuur 30 de trend weergeeft welke is berekend door het model (Model_6) op basis van de vierdemachtswortel-getransformeerde biomassa ( $y$-as).

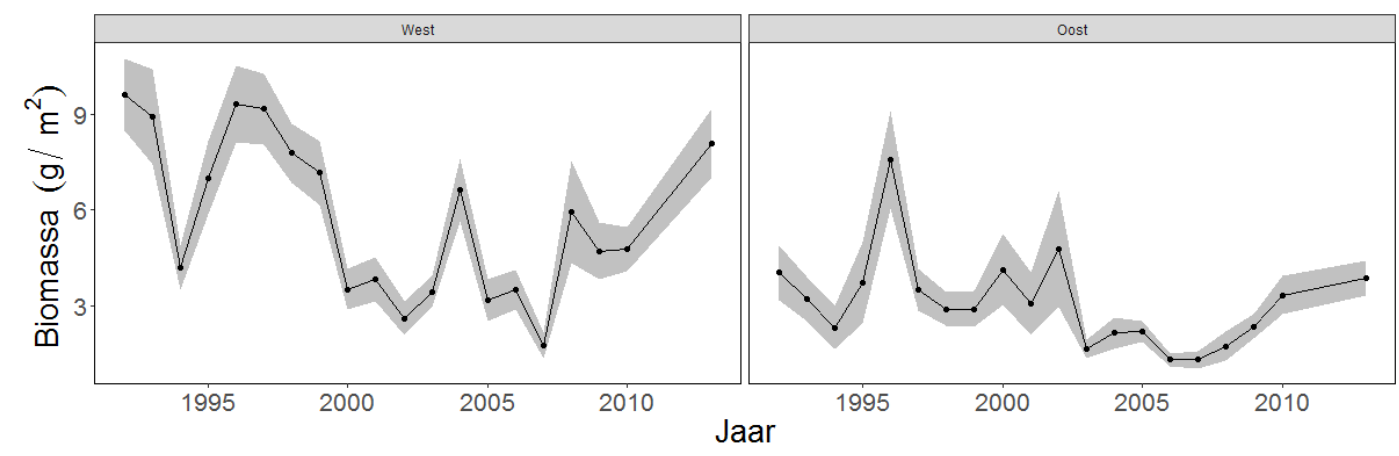

Figuur 31. Grafiek van de gemiddelde biomassa $\left(\mathrm{g} / \mathrm{m}^{2}\right)$ van Annelida per jaar in het westelijk (links) en oostelijk (rechts) deel van het Grevelingenmeer in de periode 1992 tot 2013.
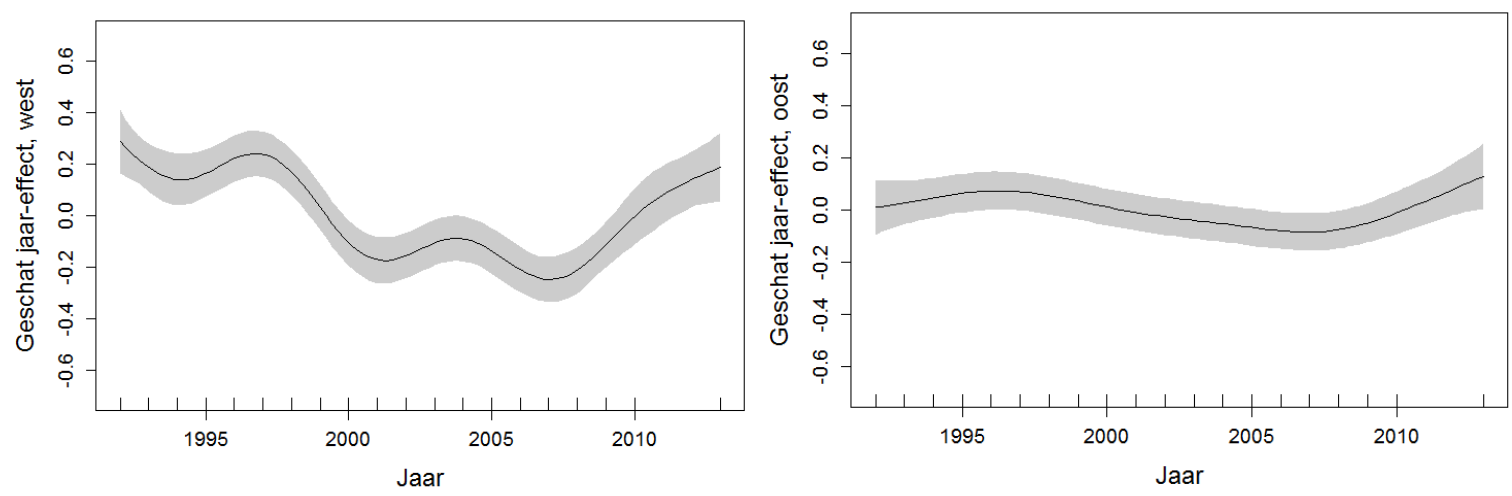

Figuur 30. Het geschatte effect van jaar op de vierdemachtswortel-getransformeerde biomassa $\left(\mathrm{g} / \mathrm{m}^{2}\right)$ van Annelida in het westelijk (links) en oostelijk (rechts) deel van het Grevelingenmeer in de periode 1992-2013. De getrokken lijn geeft het resultaat van het GAMM model over alle data. Het grijze gebied geeft het 95\%betrouwbaarheidsinterval weer. 
Beide trends zijn in Figuur 30 op dezelfde schaal geplot waardoor het verschil tussen deelgebieden direct kan worden vergeleken. In het westelijk deel is een dalende trend te zien in biomassa van 1992 tot ongeveer 2008, alhoewel de biomassa in de periode 1996-1997 en 2003-2004 weer even kort toeneemt. Een zelfde soort trend is zichtbaar in 2010 en 2013. In het oostelijk deel van het Grevelingenmeer ontbreken deze schommelingen en blijft de gemiddelde biomassa vrij constant in de periode 1992 tot 2013 met een lichte daling van 1997 tot 2007.

In het westelijk deel van het Grevelingenmeer zorgde voornamelijk de zeeduizendpoot (Alitta virens) voor een stijging in biomassa (20-62 g/m² op bepaalde stations) tussen 1996-1997, en zowel de zeeduizendpoot als de wadpier (Arenicola) zorgden voor een stijging in biomassa in 2004, 2008 en 2013. In het oostelijk deel zorgt alleen de zeeduizendpoot voor de piek in 1996 en 2000, en zorgden zowel de zeeduizendpoot ( $29-135 \mathrm{~g} / \mathrm{m}^{2}$ op bepaalde stations) als de slangpier (Capitella) ( $29 \mathrm{~g} / \mathrm{m}^{2} \mathrm{op}$ één station) voor de piek in 2002 (Figuur 31).

Het GAMM-model geeft ook aan dat waterdiepte een significant effect heeft op biomassa $(p<0.001)$. In ondiep water is de biomassa laag maar significant toe tot een waterdiepte van ongeveer 3-4 meter onder NAP. Vanaf 3-4 m onder NAP neemt de biomassa significant af tot ongeveer $15 \mathrm{~m}$ waar het betrouwbaarheidsinterval toeneemt door het geringe aantal monsters dat genomen zijn op deze diepte (Figuur 16). Wanneer het diepte-effect wordt vergeleken met het diepte-effect op de biomassa van Mollusca is te zien dat diepte een sterker effect heeft op Mollusca dan Annelida (Figuur 8 en 13).

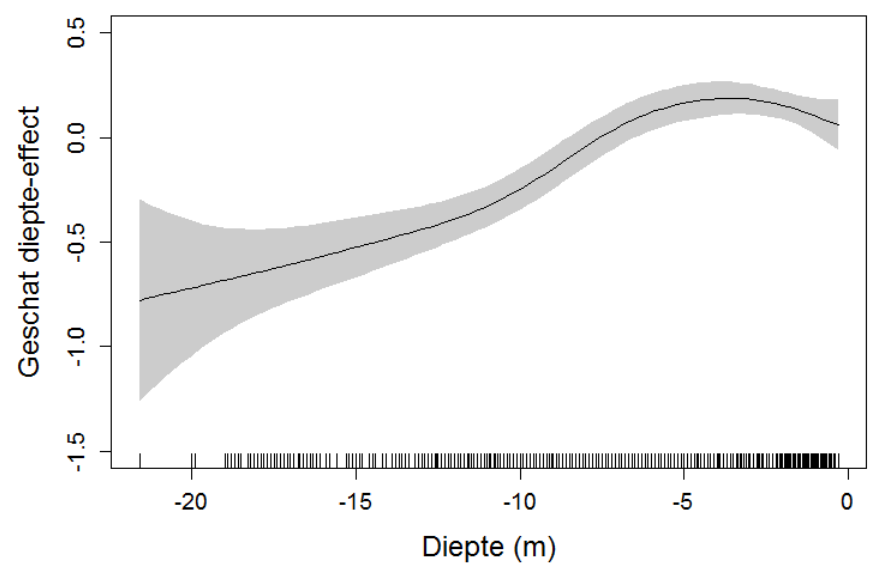

Figuur 32. Het geschatte effect van diepte (m, t.o.v. NAP) op de vierdemachtswortel-getransformeerde biomassa $\left(\mathrm{g} / \mathrm{m}^{2}\right)$ van Annelida. De getrokken lijn geeft het resultaat van het GAMM model over alle data. Het grijze gebied geeft het 95\%-betrouwbaarheidsinterval weer.

\subsubsection{Phylum Arthropoda}

Uit de GAMM-analyse blijkt dat Model_5 (Tabel 2), waar het jaar effect varieert met het seizoen, de meeste variatie verklaart in de biomassa van Arthropoda. Het GAMM model toont significante trends $(p<0.001)$ van biomassa in de tijd in beide seizoenen (Figuur 33). Figuur 34 geeft de gemiddelde biomassa $\left(\mathrm{g} / \mathrm{m}^{2}\right)$ per jaar weer in de periode 1992-2013 terwijl Figuur 33 de trend weergeeft welke is berekend door het model (Model_5) op basis van de vierdemachtswortel-getransformeerde biomassa (y-as). 

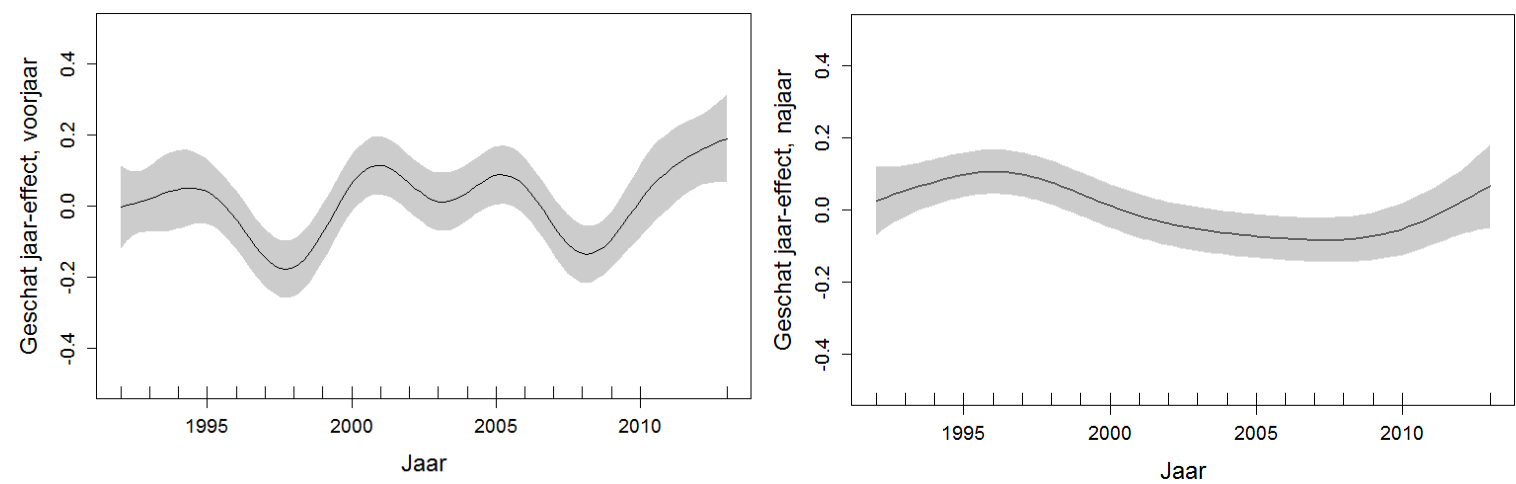

Figuur 33. Het geschatte effect van jaar op de vierdemachtswortel-getransformeerde biomassa $\left(\mathrm{g} / \mathrm{m}^{2}\right)$ van Arthropoda in het voor- (links) en najaar (rechts) in de periode 1992 tot 2013. De getrokken lijn geeft het resultaat van het GAMM model (Model_5) over alle data. Het grijze gebied geeft het 95\%betrouwbaarheidsinterval weer.

Beide trends zijn op dezelfde schaal geplot waardoor het verschil tussen seizoenen direct kan worden vergeleken (Figuur 33). In het voorjaar fluctueert biomassa sterk over de jaren heen (Figuur 33 links) waarin het tweemaal sterk afneemt in de periode 1997-1998 en 2008-2009. In 2010 en 2013 neemt de biomassa weer toe. De biomassa in het najaar daarentegen is relatief stabiel met een lichte daling van 1997 tot 2008 (Figuur 33 - rechts). De gemiddelde biomassa verschilt niet per deelgebied $(p>0.05)$.

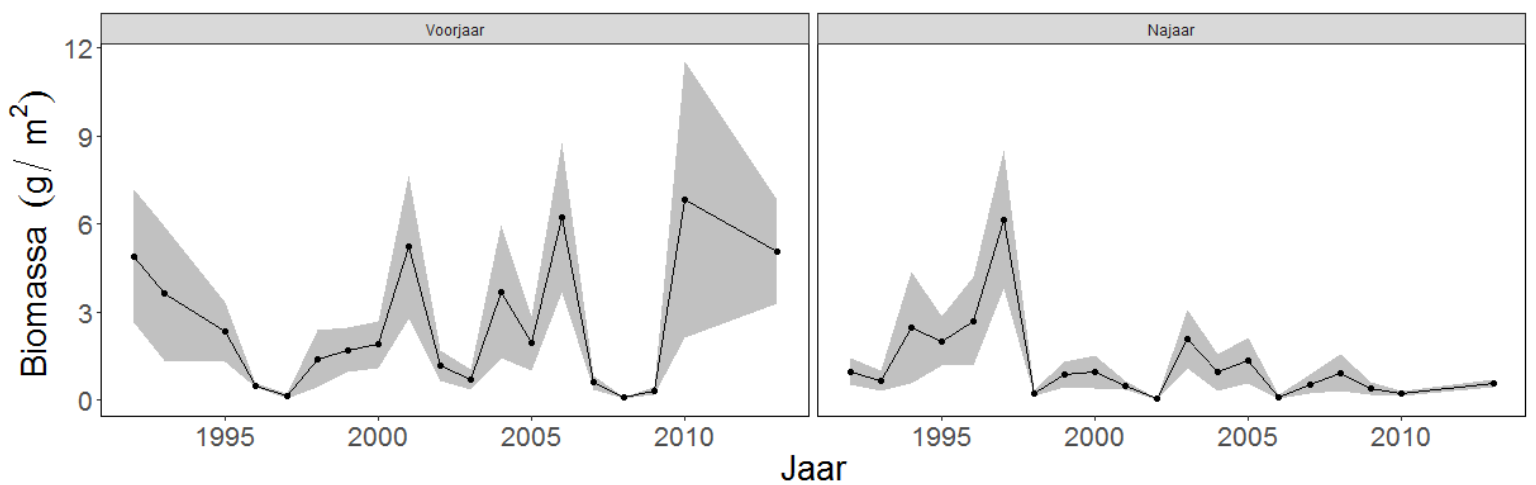

Figuur 34. Grafiek van de gemiddelde biomassa $\left(\mathrm{g} / \mathrm{m}^{2}\right)$ van Arthropoda per jaar in het voor- (links) en najaar (rechts) in de periode 1992 tot 2013. Het grijze gebied geeft de standard error weer.

De fluctuaties in het voorjaar zijn te wijden aan het bemonsteren van een aantal grote krabben welke de gemiddelde biomassa sterk omhoog haalden. Zo zijn in 1992, 2001, 2004 en 2010 een aantal grote strandkrabben (Carcinus maenas) bemonsterd met een biomassa variërend van 78 tot $399 \mathrm{~g} \mathrm{per} \mathrm{m}^{-2}$. In 2006 zijn daarnaast ook een aantal zwemkrabben aangetroffen waaronder de gewimperde zwemkrab (Liocarcinus navigator) (14-199 $\mathrm{g} / \mathrm{m}^{2}$ op bepaalde stations). In het najaar zijn minder grote krabben aangetroffen waardoor de biomassa minder fluctueert (Figuur 34).

Het GAMM-model geeft ook aan dat waterdiepte ( $x$-as) een significant effect heeft op de biomassa ( $y$ as) $(p<0.001)$ (Figuur 35$)$. In ondiepe wateren is de biomassa laag maar neemt significant toe tot een waterdiepte van ongeveer 5 meter onder NAP. Vanaf $5 \mathrm{~m}$ onder NAP neemt de biomassa weer significant af tot ongeveer $15 \mathrm{~m}$ waar het betrouwbaarheidsinterval toeneemt door het geringe aantal monsters dat genomen zijn op deze diepte. Wanneer het effect van waterdiepte op biomassa wordt vergeleken tussen de drie phyla: Mollusca (Figuur 29), Annelida (Figuur 32) en Arthropoda (Figuur $35)$, is de relatie tussen de twee variabelen het sterkst voor Mollusca. 


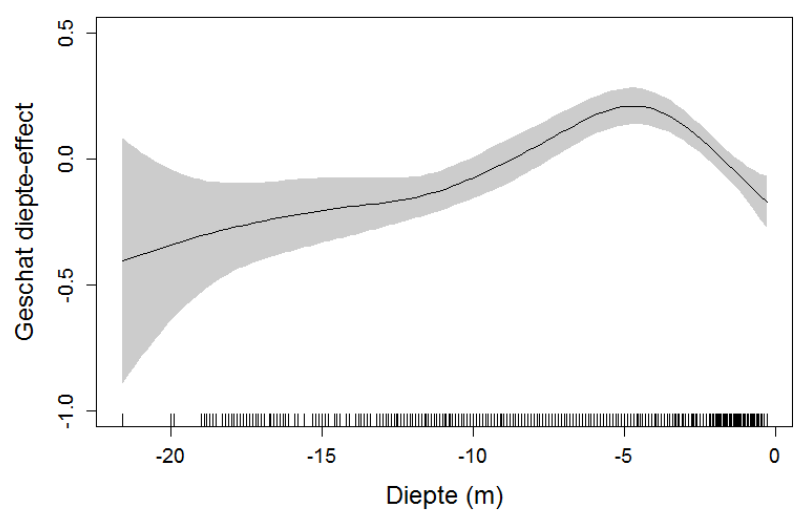

Figuur 35. Het geschatte effect van diepte (m, t.o.v. NAP) op de vierdemachtswortel-getransformeerde biomassa $\left(\mathrm{g} / \mathrm{m}^{2}\right)$ van Arthropoda. De getrokken lijn geeft het resultaat van het GAMM model over alle data. Het grijze gebied geeft het 95\%-betrouwbaarheidsinterval weer. 


\subsubsection{Dichtheid}

\subsubsection{Algemeen}

Uit de GAMM-analyse blijkt dat Model_2 (Tabel 2) de meeste variatie verklaart in dichtheid. De linkergrafiek in Figuur 36 geeft de gemiddelde dichtheid $\left(\# / \mathrm{m}^{2}\right)$ per jaar weer in de periode 1992-2016 terwijl de rechtergrafiek de trend weergeeft welke is berekend door het model (Model_2) op basis van de vierdemachtswortel-getransformeerde dichtheid (y-as). Het GAMM-model geeft aan dat jaar (x-as) een significant effect heeft op de dichtheid $(p<0.001)$ (Figuur $36-R$ ) wat betekent dat er een significante trend waarneembaar is van dichtheid in de tijd. De vorm van de trend verschilt niet per seizoen of deelgebied (afwezigheid van interactie tussen de verklarende variabele). De trend geeft aan dat dichtheid sterk fluctueert over de jaren heen waarbij deze sterk toeneemt in de periode 19951997, 2002-2004 en in 2016. Wel is de dichtheid gemiddeld iets hoger in het voorjaar dan in het najaar $(p<0.001)$ en gemiddeld hoger in het westelijke deel dan in het oostelijke deel $(p<0.001)$ van het Grevelingenmeer. Het verschil in dichtheid is groter tussen deelgebieden dan tussen seizoenen.
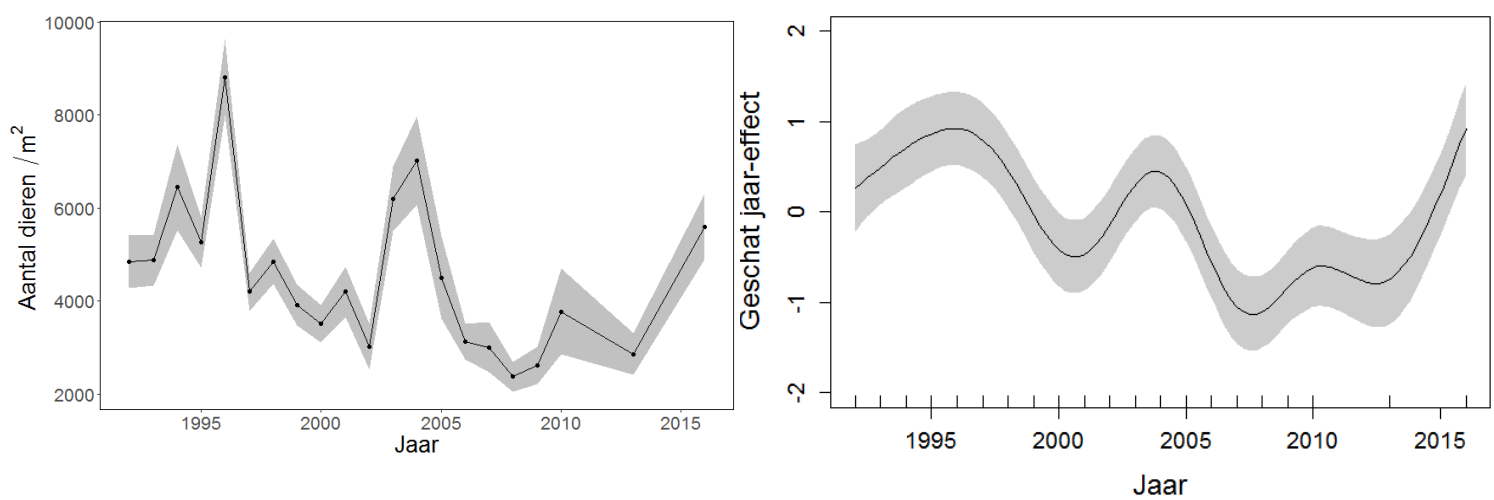

Figuur 36. Links - Grafiek van de middelde totale dichtheid $\left(\# / \mathrm{m}^{2}\right)$ per jaar in de periode 1992 tot 2016. Het grijze gebied geeft de standard error weer. Rechts - Het geschatte effect van jaar op de vierdemachtswortel-getransformeerde totale dichtheid $\left(\# / \mathrm{m}^{2}\right)$ in de periode 1992 tot 2016. De getrokken lijn geeft het resultaat van het GAMM model (Model_2) over alle data. Het grijze gebied geeft het 95\%betrouwbaarheidsinterval weer.

Het GAMM-model geeft ook aan dat waterdiepte ( $x$-as) een significant effect heeft op de dichtheid ( $y$ as) $(p<0.001)$. De vorm van de trend verschilt echter wel per seizoen (Figuur 37). Beide trends zijn op dezelfde schaal geplot waardoor het verschil tussen seizoenen direct met elkaar kan worden vergeleken. In het najaar is de dichtheid laag in ondiep water maar neemt significant toe tot een diepte van ongeveer 6 meter onder NAP. Vanaf 6 meter onder NAP neemt de dichtheid weer significant af tot ongeveer $15 \mathrm{~m}$ waar het betrouwbaarheidsinterval toeneemt door het geringe aantal monsters dat genomen zijn op deze diepte (Figuur 37 - R). In het voorjaar is een zelfde soort trend te zien maar de relatie tussen waterdiepte en dichtheid is minder sterk en het verschil in dichtheid dus minder tussen ondiepe en diepere delen.
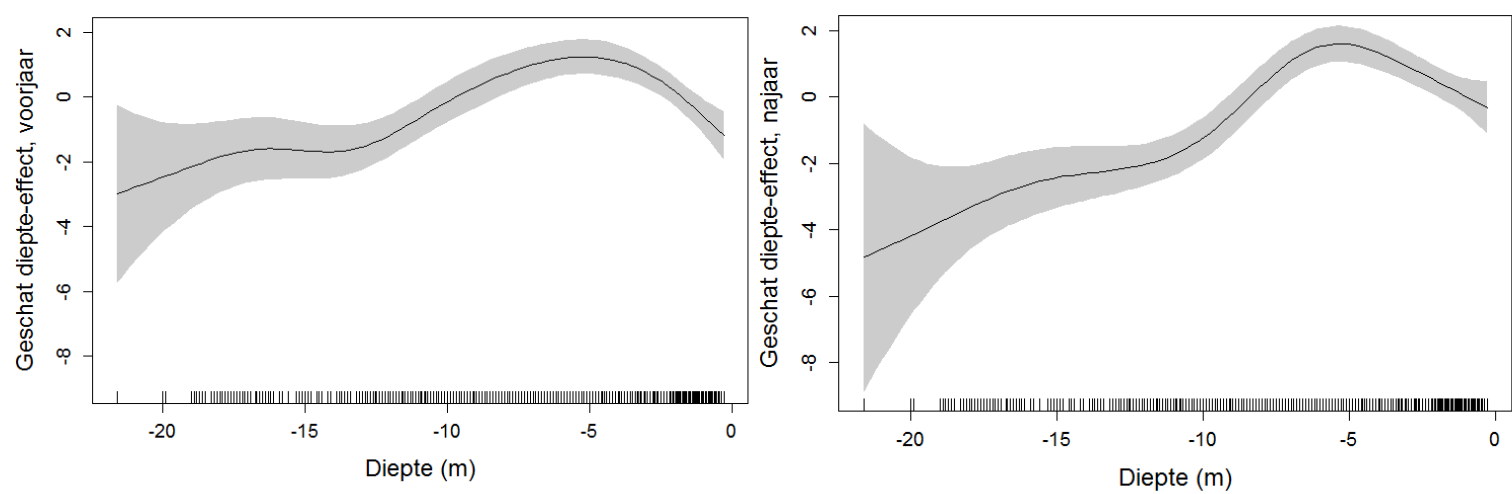

Figuur 37. Het geschatte effect van diepte ( $m$, t.o.v. NAP) op de vierdemachtswortel-getransformeerde totale dichtheid $\left(\# / \mathrm{m}^{2}\right)$ in het voor- (links) en najaar (rechts) in het Grevelingenmeer in de periode 19922016. De getrokken lijn geeft het resultaat van het GAMM model (Model_2) over alle data. Het grijze gebied geeft het 95\%-betrouwbaarheidsinterval weer. 


\subsubsection{Phylum Mollusca}

Uit de GAMM-analyse blijkt dat Model_5 (Tabel 2), waar het jaar effect varieert per seizoen, de meeste variatie in de dichtheid verklaart. Figuur 38 geeft de gemiddelde dichtheid $\left(\# / \mathrm{m}^{2}\right)$ per jaar weer voor elk seizoen voor de periode 1992-2016 terwijl Figuur 39 de trend weergeeft welke is berekend door het model (Model_5) op basis van de vierdemachtswortel-getransformeerde dichtheid ( $y$-as). Het GAMM-model toont significante trends $(p<0.001)$ van dichtheid in de tijd in beide seizoenen waar de vorm van de trend verschilt per seizoen (Figuur 39).

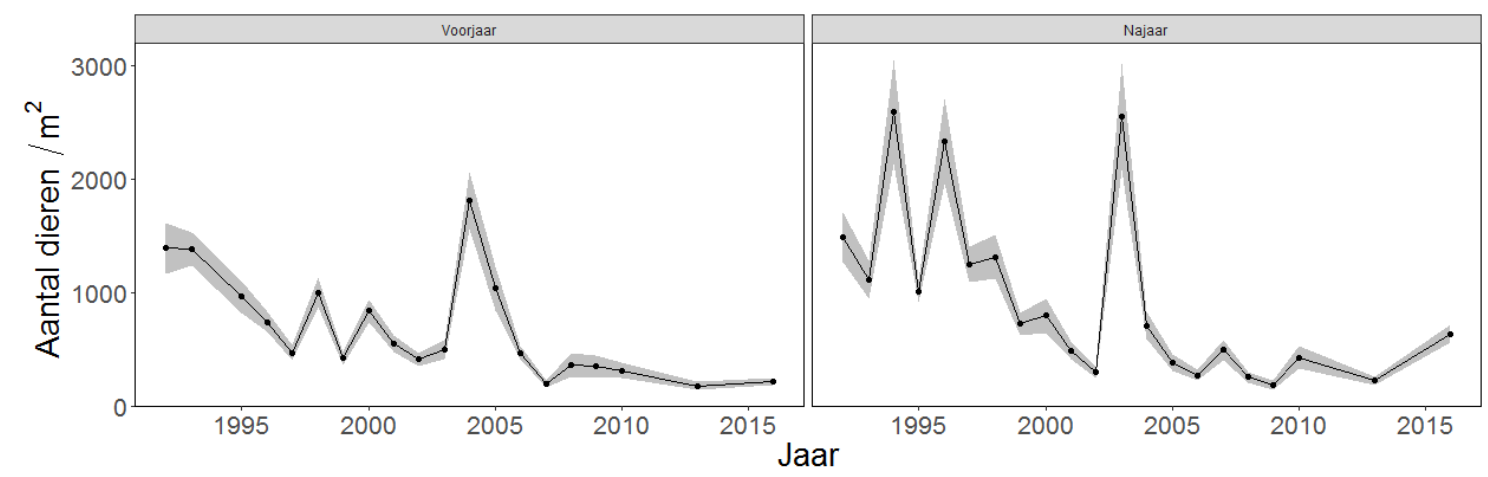

Figuur 38. Grafiek van de gemiddelde dichtheid $\left(\# / \mathrm{m}^{2}\right)$ van Mollusca in het voor- (links) en najaar (rechts) in het Grevelingenmeer in de periode 1992 tot 2016. Het grijze gebied geeft de standard error weer.

Beide trends zijn op dezelfde schaal geplot waardoor het verschil tussen seizoenen kan worden vergeleken (Figuur 39). In het voorjaar fluctueert de dichtheid sterk over de jaren heen en daalt vooral snel in de periode 2005 tot 2008. In het najaar is een dalende trend al duidelijk zichtbaar vanaf 1995 tot 2008 waarna weer een hoge dichtheid is gemeten in 2016 . Alhoewel de vorm van de trend verschilt, blijft de gemiddelde dichtheid hetzelfde per seizoen $(p>0.050)$. Wel ligt de dichtheid gemiddeld wat hoger in het westelijke deel dan in het oostelijke deel $(p<0.050)$ van het Grevelingenmeer.
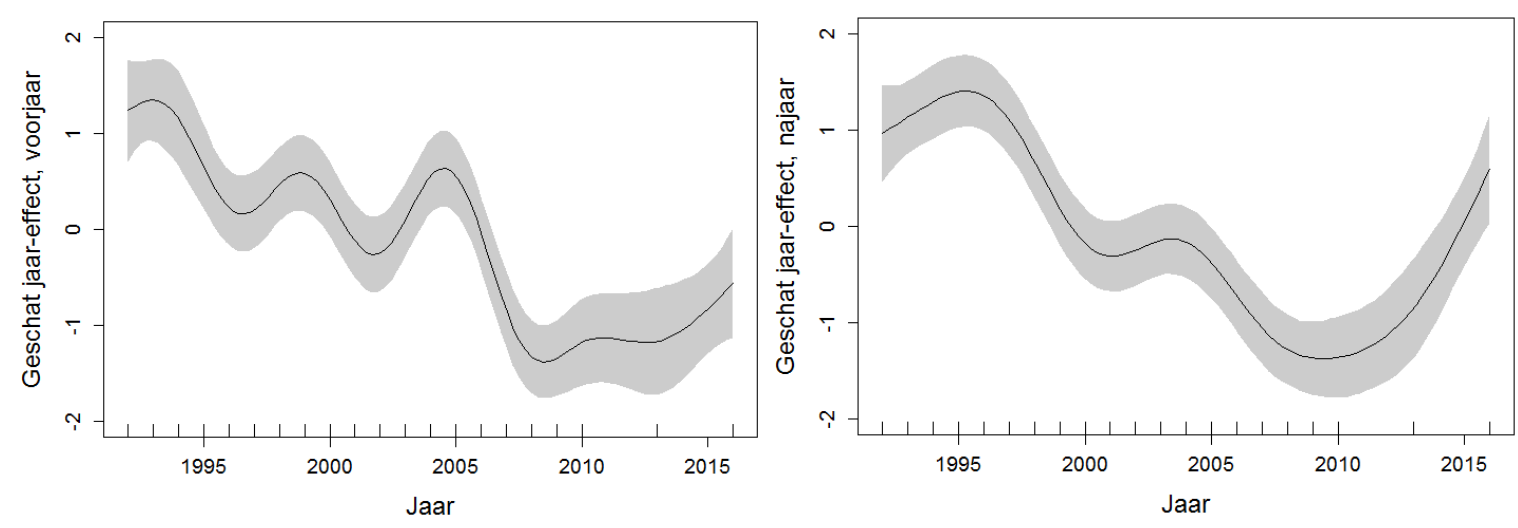

Figuur 39. Het geschatte effect van jaar op de vierdemachtswortel-getransformeerde dichtheid (\#/m $\left.{ }^{2}\right)$ van Mollusca in het voor- (links) en najaar (rechts) in het Grevelingenmeer in de periode 1992 tot 2016. De getrokken lijn geeft het resultaat van het GAMM model (Model_5) over alle data. Het grijze gebied geeft het 95\%-betrouwbaarheidsinterval weer.

In het voorjaar zorgden voornamelijk het muiltje (Crepidula fornicata) voor een stijging in dichtheden in 1993 en 1999 met in bepaalde stations 1200 tot 4000 individuen per m² (Figuur 38). Ook andere soorten waren verantwoordelijk voor de pieken zoals het wadslakje (Peringia ulvae) in 1993 (tot 4800 ind $/ \mathrm{m}^{2}$ ), de glanzende dunschaal (Abra nitida) in 1999 (tot $1200 \mathrm{ind} / \mathrm{m}^{2}$ ) en de korfschelp (Corbula gibba) en tweetandschelp (Kurtiella bidentata) in 2004 met dichtheden tot 2500 individuen per $\mathrm{m}^{-2}$. In het najaar 1996 waren dichtheden nog hoog met 20,100 muiltjes per $\mathrm{m}^{-2}$ maar daarna namen 
dichtheden sterk af. Door een toename aan korf- en tapijtschelpen (Venerupis corrugata) ( 1200 ind $/ \mathrm{m}^{2}$ ) is de dichtheid weer wat toegenomen in het najaar 2016.

Het GAMM-model geeft ook aan dat waterdiepte ( $x$-as) een significant effect heeft op dichtheid $(p<0.001)$ (Figuur 40). In de ondiepe wateren is de dichtheid laag maar neemt significant toe tot een diepte van ongeveer 6 meter onder NAP. Vanaf 6 meter onder NAP neemt de dichtheid weer significant af tot ongeveer $12 \mathrm{~m}$ waar het betrouwbaarheidsinterval toeneemt door het geringe aantal monsters dat genomen zijn op deze diepte.

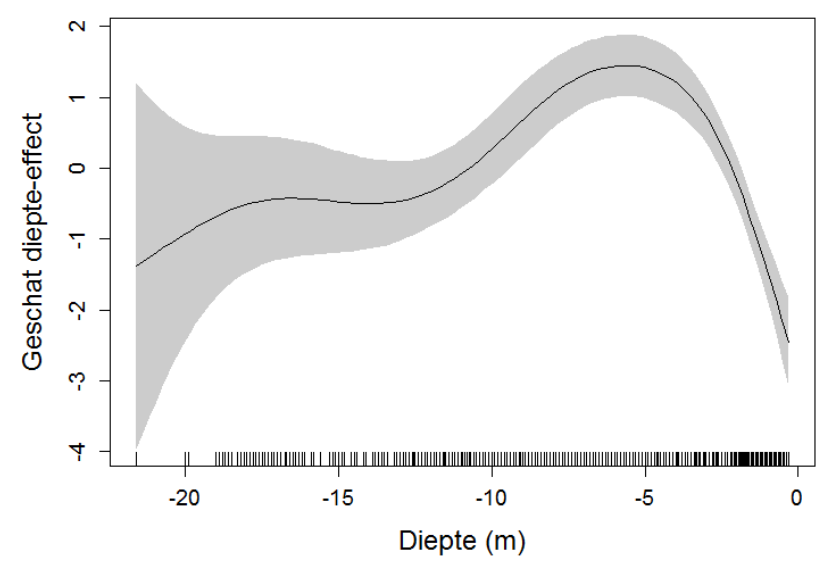

Figuur 40. Het geschatte effect van diepte (m, t.o.v. NAP) op de vierdemachtswortel-getransformeerde dichtheid $\left(\# / \mathrm{m}^{2}\right)$ van Mollusca. De getrokken lijn geeft het resultaat van het GAMM model (Model_5) over alle data. Het grijze gebied geeft het $95 \%$ betrouwbaarheidsinterval weer.

\subsubsection{Phylum Annelida}

Uit de GAMM-analyse blijkt dat Model_2 (Tabel 2) de meeste variatie verklaart in de dichtheid. De linker-grafiek in Figuur 41 geeft de gemiddelde dichtheid aan per jaar in de periode 1992-2016 terwijl de rechter-grafiek de trend weergeeft welke is berekend door het model (Model_2) op basis van de vierdemachtswortel-getransformeerde dichtheid ( $y$-as). Het GAMM-model geeft aan dat er een significante trend waarneembaar is van dichtheid in de tijd $(p<0.001)$ (Figuur $41-R)$. De vorm van de trend verschilt niet per deelgebied en/of seizoen (afwezigheid van interactie tussen verklarende variabele) maar de dichtheid is gemiddeld hoger in het voorjaar dan in het najaar $(p<0.001)$. Tevens is de dichtheid gemiddeld hoger in het westelijke deel van het Grevelingenmeer in vergelijking met het oostelijke deel $(p<0.001)$.
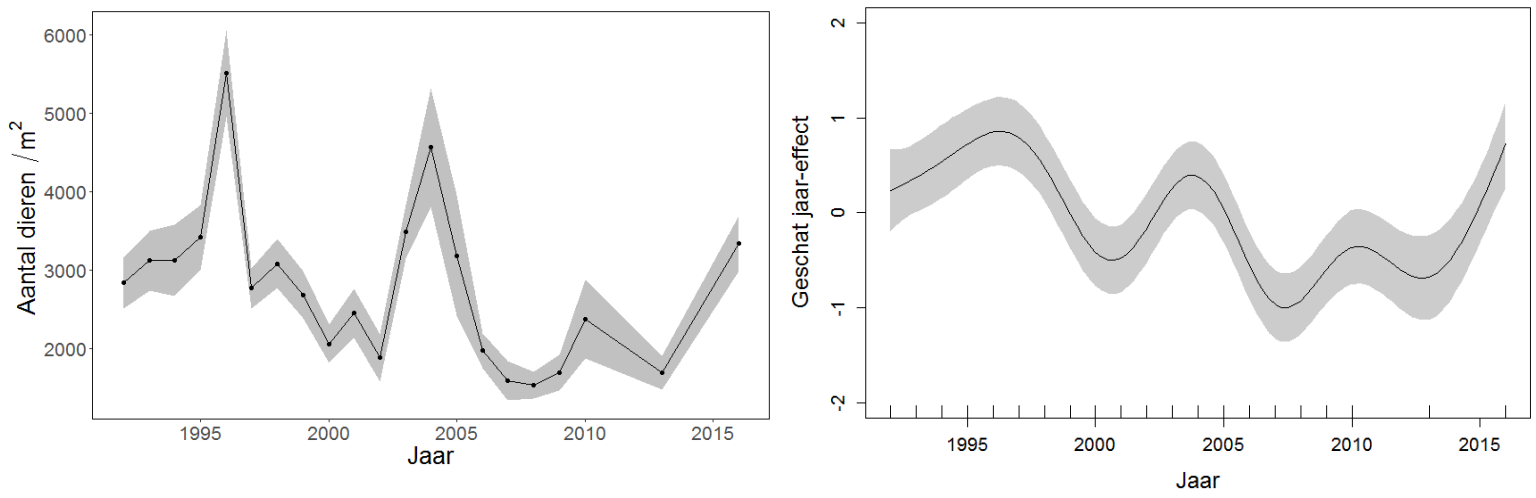

Figuur 41. Links - Grafiek van de gemiddelde dichtheid $\left(\# / \mathrm{m}^{2}\right)$ van Annelida per jaar in de periode 1992 tot 2016. Het grijze gebied geeft de standard error weer. Rechts - Het geschatte effect van jaar op de vierdemachtswortel-getransformeerde dichtheid $\left(\# / \mathrm{m}^{2}\right)$ van Annelida in de periode 1992-2016. De getrokken lijn geeft het resultaat van het GAMM model (Model_2) over alle data. Het grijze gebied geeft het 95\%-betrouwbaarheidsinterval weer.

De schommelingen in dichtheden (Figuur 41 - links) worden onder andere veroorzaakt door Oligochaeten en slikkokerwormen (Polydora ciliata) welke in grote getalen voorkwamen in 1996 (10,000-23,000 ind $/ \mathrm{m}^{2}$ op bepaalde stations). Daarnaast waren de genera Polydora en Capitella verantwoordelijk voor de toenemende dichtheden in $2004\left(12,000-25,000 \mathrm{ind} / \mathrm{m}^{2}\right)$ en de borstelworm Streblospio voor de piek in 2016 (14,000-18,000 ind $/ \mathrm{m}^{2}$ op bepaalde stations). 
Het GAMM-model geeft ook aan dat waterdiepte ( $x$-as) een significant effect heeft op dichtheid ( $y$-as) $(p<0.001)$, alhoewel de vorm van de trend verschilt per seizoen (Figuur 42). Beide trends zijn op dezelfde schaal geplot waardoor het verschil tussen seizoenen direct kan worden vergeleken. In beide seizoenen is de dichtheid in ondiep water laag maar neemt significant toe tot een diepte van 5-6 meter onder NAP. Vanaf deze diepte neemt de dichtheid weer significant af tot ongeveer 12-15 m waar het betrouwbaarheidsinterval toeneemt door het geringe aantal monsters dat genomen zijn op deze diepte. In het voorjaar is de relatie tussen diepte en dichtheid wat minder sterk in vergelijking met het najaar.
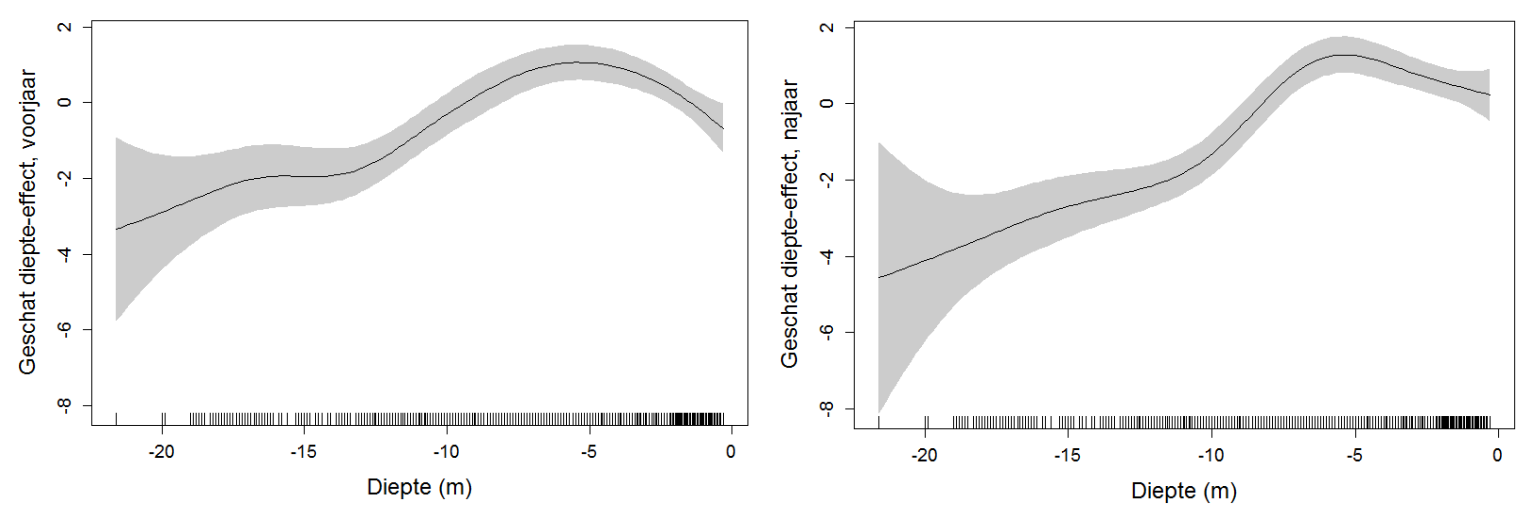

Figuur 42. Het geschatte effect van diepte ( $m$, t.o.v. NAP) op de vierdemachtswortel-getransformeerde dichtheid $\left(\# / \mathrm{m}^{2}\right)$ van Annelida in het voor- (links) en najaar (rechts) in de periode 1992 tot 2016. De getrokken lijn geeft het resultaat van het GAMM model (Model_2) over alle data. Het grijze gebied geeft het 95\%-betrouwbaarheidsinterval weer.

\subsubsection{Phylum Arthropoda}

Uit de GAMM-analyse blijkt dat Model_5 (Tabel 2), waar het jaar effect varieert met het seizoen, de meeste variatie in de data verklaart. Figuur 44 geeft de gemiddelde dichtheid $\left(\# / \mathrm{m}^{2}\right)$ per jaar weer in de periode 1992-2016 terwijl Figuur 43 de trend weergeeft welke is berekend door het model (Model_2) op basis van de vierdemachtswortel-getransformeerde dichtheid ( $y$-as). Het GAMM model toont significante trends $(p<0.001)$ van dichtheid in de tijd in beide seizoenen (Figuur 43 ).

Beide trends zijn op dezelfde schaal geplot waardoor het verschil tussen seizoenen direct kan worden vergeleken. In het voorjaar fluctueert de dichtheid sterk over de jaren heen (Figuur 43 - links) waarin het driemaal significant toeneemt in de periode 1995, 2002-2003 en 2013-2016. De dichtheid in het najaar daarentegen is relatief stabiel met een significante daling van 1997 tot 2010 (Figuur 43 rechts). De dichtheid in 2016 is significant toegenomen maar meer data moet uitwijzen of dit een lange termijn trend is of een eenmalige toename. De gemiddelde dichtheid verschilt niet per deelgebied of seizoen $(p>0.050)$.
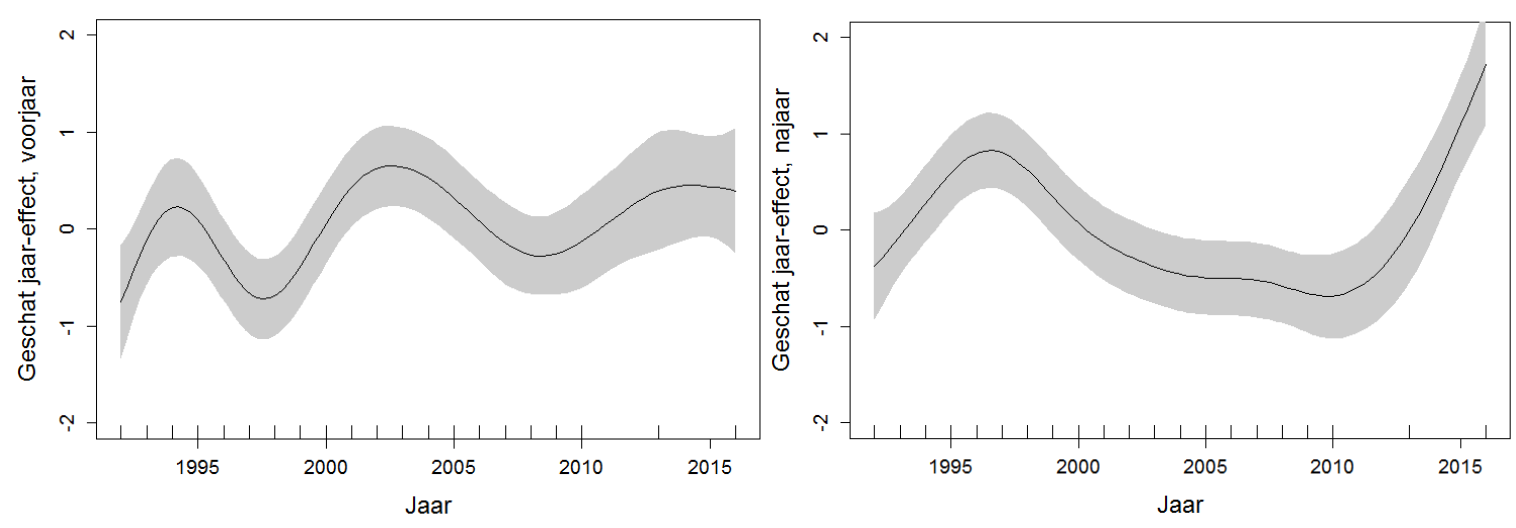

Figuur 43. Het geschatte effect van jaar op de vierdemachtswortel-getransformeerde dichtheid (\#/m $\left.{ }^{2}\right)$ van Arthropoda in het voor- (links) en najaar (rechts) in de periode 1992 tot 2016. De getrokken lijn geeft het resultaat van het GAMM model (Model_5) over alle data. Het grijze gebied geeft het 95\%-

betrouwbaarheidsinterval weer. 


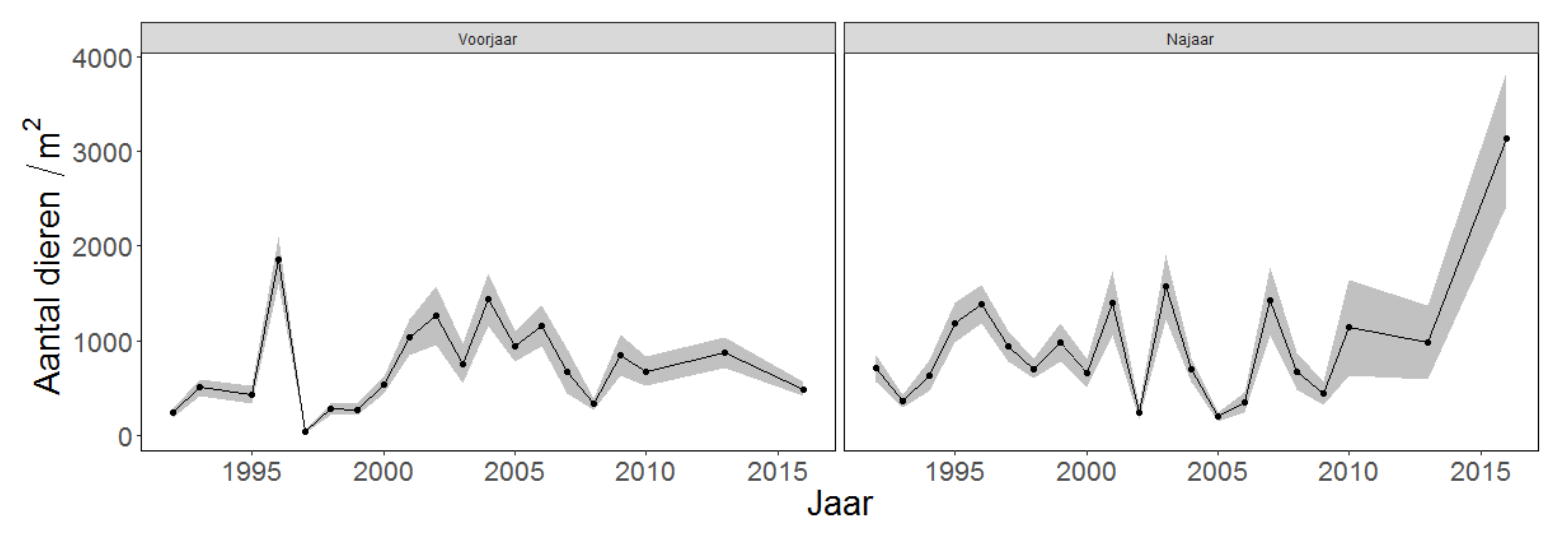

Figuur 44. De gemiddelde dichtheid $\left(\# / \mathrm{m}^{2}\right)$ van Arthropoda per jaar in het voor- (links) en najaar (rechts) in de periode 1992 tot 2016. Het grijze gebied geeft de standard error weer.

In het voorjaar zorgen voornamelijk de vlokreeftjes Microdeutopus gryllotalpa en Monocorophium insidiosum voor hoge dichtheden in zowel 1995, 2002-2003 als 2013-2016 met dichtheden van 1600 tot 12,200 individuen per $\mathrm{m}^{-2}$ op bepaalde stations. Hoge dichtheden in het najaar worden ook veroorzaakt door de families Aoridae en Corophiidae in 1997 en 2016 (Figuur 44).

Het GAMM-model geeft ook aan dat waterdiepte ( $x$-as) een significant effect heeft op dichtheid $(p<0.001$, Figuur 45). In ondiep water is de dichtheid laag maar neemt significant toe tot een waterdiepte van 5 meter onder NAP. Vanaf $5 \mathrm{~m}$ onder NAP neemt de dichtheid weer significant af tot ongeveer $15 \mathrm{~m}$ waar het betrouwbaarheidsinterval toeneemt door het geringe aantal monsters dat genomen zijn op deze diepte. Wanneer het effect van waterdiepte op de dichtheid wordt vergeleken tussen de drie phyla: Mollusca (Figuur 40), Annelida (Figuur 42) en Arthropoda (Figuur 45), is de relatie tussen de twee variabelen (diepte en dichtheid) het sterkst voor Annelida.

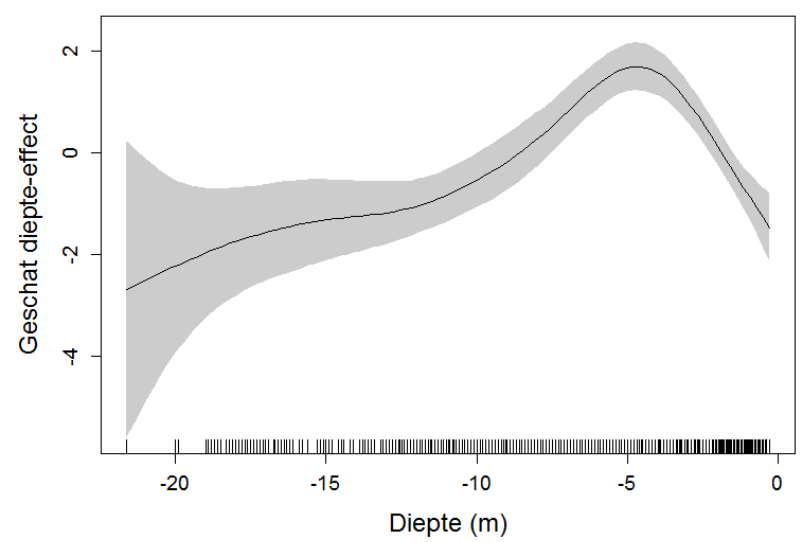

Figuur 45. Het geschatte effect van diepte (m, t.o.v. NAP) op de vierdemachtswortel-getransformeerde dichtheid $\left(\# / \mathrm{m}^{2}\right)$ van Arthropoda. De getrokken lijn geeft het resultaat weer van het GAMM model over alle data. Het grijze gebied geeft het 95\%-betrouwbaarheidsinterval weer. 


\subsubsection{Voedselgildes}

Soorten binnen een bepaald phylum of klasse kunnen er verschillende wijzen van voedselvergaring op nahouden zoals bodemeters en filtreerders maar soorten kunnen ook herbivoren, omnivoren of predatoren zijn. Door alleen naar verschillende taxonomische niveaus te kijken, is het moeilijk vast te stellen of er veranderingen optreden in de wijze van voedselvergaring. Daarom wordt er in dit hoofdstuk gekeken naar de ontwikkelingen van twee typeringen van voedselvergaring: bodemetende (deposit en (sub) surface deposit feeders) en filtrerende (suspension feeders) organismen.

\subsubsection{Bodemetende organismen (deposit en (sub) surface deposit feeders)}

\section{Dichtheid}

Uit de GAMM-analyse blijkt dat Model_2 (Tabel 2) de meeste variatie in de dichtheid verklaart. De linker-grafiek in Figuur 46 geeft de gemiddelde dichtheid $\left(\# / \mathrm{m}^{2}\right)$ per jaar weer in de periode 19922016 terwijl de rechter-grafiek de trend weergeeft welke is berekend door het model (Model_2) op basis van de vierdemachtswortel-getransformeerde dichtheid ( $y$-as). Het GAMM-model geeft aan dat jaar een significant effect heeft op dichtheid $(p<0.001)$. De vorm van de trend verschilt niet per deelgebied en/of seizoen maar de dichtheid is gemiddeld hoger in het westelijke deel van het Grevelingenmeer in vergelijking met het oostelijke deel $(p<0.001)$. Tevens is de dichtheid gemiddeld hoger in het voorjaar dan in het najaar $(p<0.001)$.
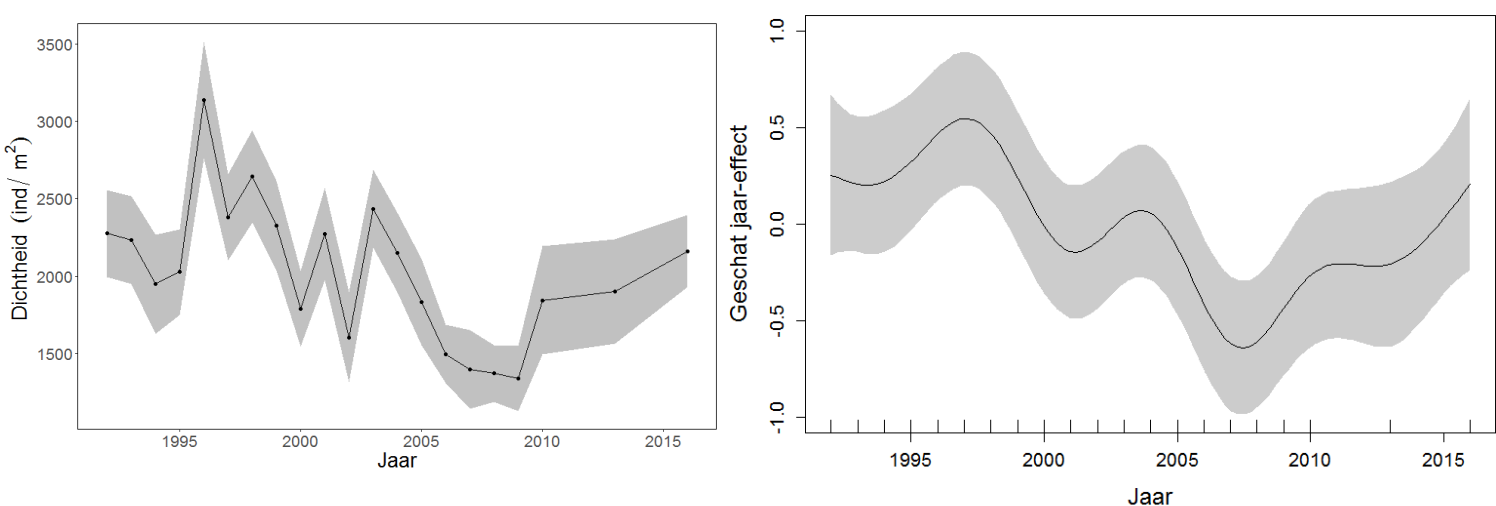

Figuur 46. Links - Grafiek van de gemiddelde dichtheid $\left(\# / \mathrm{m}^{2}\right)$ van bodemetende organismen per jaar in de periode 1992-2016. Het grijze gebied geeft de standard error weer. Rechts - Het geschatte effect van jaar op de vierdemachtswortel-getransformeerde dichtheid $\left(\# / \mathrm{m}^{2}\right)$ van bodemetende organismen in de periode 1992 tot 2016. De getrokken lijn geeft het resultaat van het GAMM model (Model_2) over alle data. Het grijze gebied geeft het 95\%-betrouwbaarheidsinterval weer.

De dichtheid neemt significant af tussen 1996/1997 en 2008 waarna het weer toeneemt in 2010 tot 2016. De piek in 1996 (Figuur 46 - links) wordt voornamelijk veroorzaakt door de grote dichtheden op bepaalde stations van Crepidula fornicata $\left(12,000-20,000 \mathrm{ind} / \mathrm{m}^{2}\right)$, Oligochaeta $(11,000-17,000$ ind $/ \mathrm{m}^{2}$ ) en Polydora ciliata (11,000-23,000 ind $/ \mathrm{m}^{2}$ ). De korfschelp (Corbula gibba) zorgt voor de piek in 2003 met dichtheden van 22,000 tot 25,000 individuen per $\mathrm{m}^{-2}$ terwijl Aoridae $\left(43,870 \mathrm{ind} / \mathrm{m}^{2}\right) \mathrm{en}$ Monocorophium acherusicum (25,532 ind $/ \mathrm{m}^{2}$ ) verantwoordelijk zijn voor de hoge dichtheden in 2013 en 2016, respectievelijk.

Het GAMM-model geeft ook aan dat waterdiepte een significant effect heeft op dichtheid $(p<0.001)$, alhoewel de vorm van de trend verschilt per seizoen. In beide seizoenen is de dichtheid in ondiep water laag en neemt significant toe tot een diepte van $5 \mathrm{~m}$ onder NAP. Vanaf deze diepte neemt de dichtheid weer significant af tot ongeveer $15 \mathrm{~m}$ waar het betrouwbaarheidsinterval toeneemt. In het voorjaar is de relatie tussen diepte en dichtheid wat minder sterk in vergelijking met het najaar. 


\section{Biomassa}

Uit de GAMM-analyse blijkt dat Model_6 (Tabel 2), waar het jaar effect varieert met deelgebied, de meeste variatie in de biomassa van bodemetende organismen verklaart. Figuur 47 geeft de trend weer in het westelijke (links) en oostelijke (rechts) deel van het Grevelingenmeer welke is berekend door het model (Model_6) op basis van de vierdemachtswortel-getransformeerde biomassa ( $y$-as). Het GAMM-model toont significante trends $(p<0.001)$ van biomassa in de tijd in beide deelgebieden. Beide trends zijn op dezelfde schaal geplot waardoor het verschil tussen deelgebieden direct kan worden vergeleken. In het westelijke deel van het Grevelingenmeer neemt de biomassa significant af tot ongeveer 2003 waarna het in 2010 en 2013 weer significant toeneemt. In het oostelijke deel is vanaf 1992 al een significante toename te zien in biomassa. De biomassa is gemiddeld hoger in het voorjaar en in het westelijke deel van het Grevelingenmeer $(p<0.001)$
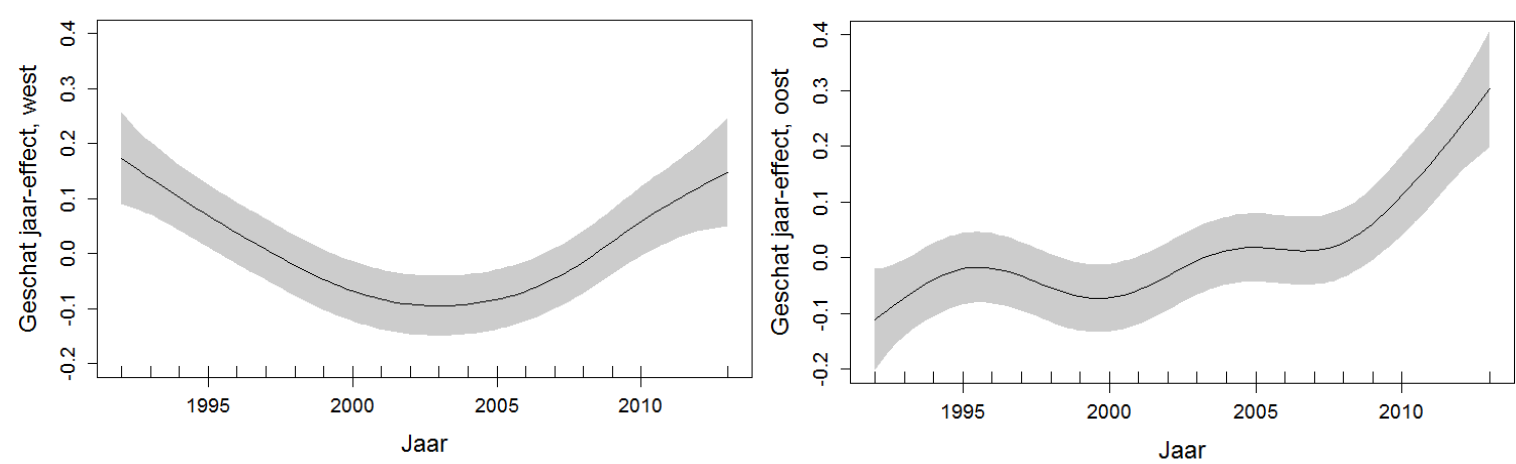

Figuur 47. Het geschatte effect van jaar op de vierdemachtswortel-getransformeerde biomassa $\left(\mathrm{g} / \mathrm{m}^{2}\right)$ van bodemetende organismen in het westelijke (links) en oostelijke (rechts) deel van het Grevelingenmeer in de periode 1992 tot 2013. De getrokken lijn geeft het resultaat van het GAMM model (Model_6) over alle data. Het grijze gebied geeft het 95\%-betrouwbaarheidsinterval weer.

In het westelijke deel van het meer zorgt voornamelijk de alikruik (Littorina littorea) voor een hoge biomassa op bepaalde stations (tot $98 \mathrm{~g} / \mathrm{m}^{2}$ ) in 1992. Na de afnemende trend in biomassa zorgden de wadpieren (Arenicola spp.) weer voor een toename in biomassa in 2010 en polychaeta, zoals Alitta succinea (18 g/m² op één station) en Arenicola spp. (tot $49 \mathrm{~g} / \mathrm{m}^{2}$ op bepaalde stations), voor een toename in 2013. De toename van biomassa in het oostelijke deel van het meer wordt voornamelijk veroorzaakt door de wadpieren met op bepaalde stations een biomassa tot $32 \mathrm{~g} / \mathrm{m}^{2}$.

Het GAMM-model geeft ook aan dat waterdiepte een significant effect heeft op de biomassa $(p<0.001)$. De biomassa piekt rond $5 \mathrm{~m}$ onder NAP en neemt wat af in ondieper water. Vanaf $5 \mathrm{~m}$ neemt de dichtheid significant af tot ongeveer $15 \mathrm{~m}$ onder NAP waar het betrouwbaarheidsinterval toeneemt.

\subsubsection{Filtrerende organismen (suspension feeders)}

\section{Dichtheid}

Uit de GAMM-analyse blijkt dat Model_5 (Tabel 2), waar het jaar effect varieert met het seizoen, de meeste variatie verklaart in de dichtheid. Figuur 48 geeft de gemiddelde dichtheid $\left(\# / \mathrm{m}^{2}\right)$ per jaar weer in de periode 1992-2016 terwijl Figuur 49 de trend weergeeft welke is berekend door het model (Model_5) op basis van de vierdemachtswortel-getransformeerde dichtheid ( $y$-as). Het GAMM-model geeft aan dat jaar een significant effect heeft op dichtheid waarbij de vorm van de trend significant verschilt per seizoen $(p<0.001)$. Beide trends zijn op dezelfde schaal geplot waardoor het verschil tussen seizoenen direct kan worden vergeleken. Daarnaast is de dichtheid gemiddeld hoger $(p<0.001)$ in het westelijke deel van het Grevelingenmeer in vergelijking met het oostelijke deel. Tevens is de dichtheid hoger $(p<0.001)$ in het najaar dan in het voorjaar. Het verschil is groter tussen deelgebieden dan tussen seizoenen. 


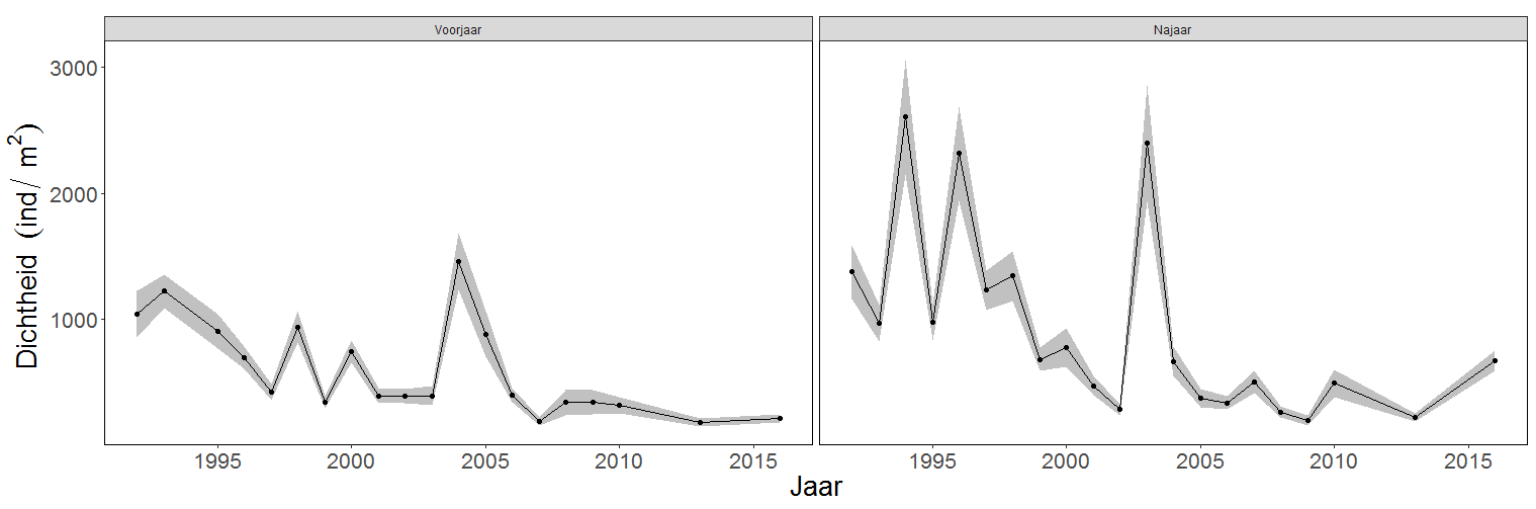

Figuur 48. De gemiddelde dichtheid $\left(\# / \mathrm{m}^{2}\right)$ van filtrerende organismen per jaar in het voor- (links) en najaar (rechts) in de periode 1992 tot 2016. Het grijze gebied geeft de standard error weer.

In het voorjaar fluctueert de dichtheid over de jaren heen (Figuur 48- links). Deze fluctuaties worden voornamelijk veroorzaakt door het muiltje in zowel 1993 als 1998. De korfschelp (Corbula gibba) brengt met 7500 tot 25,133 ind/m² (op bepaalde stations) de gemiddelde dichtheid omhoog in 2004 . Dezelfde soorten zijn verantwoordelijk voor de pieken in het najaar. Het muiltje voor de pieken in 1994 en 1996 en de korfschelp voor de piek in 2003.
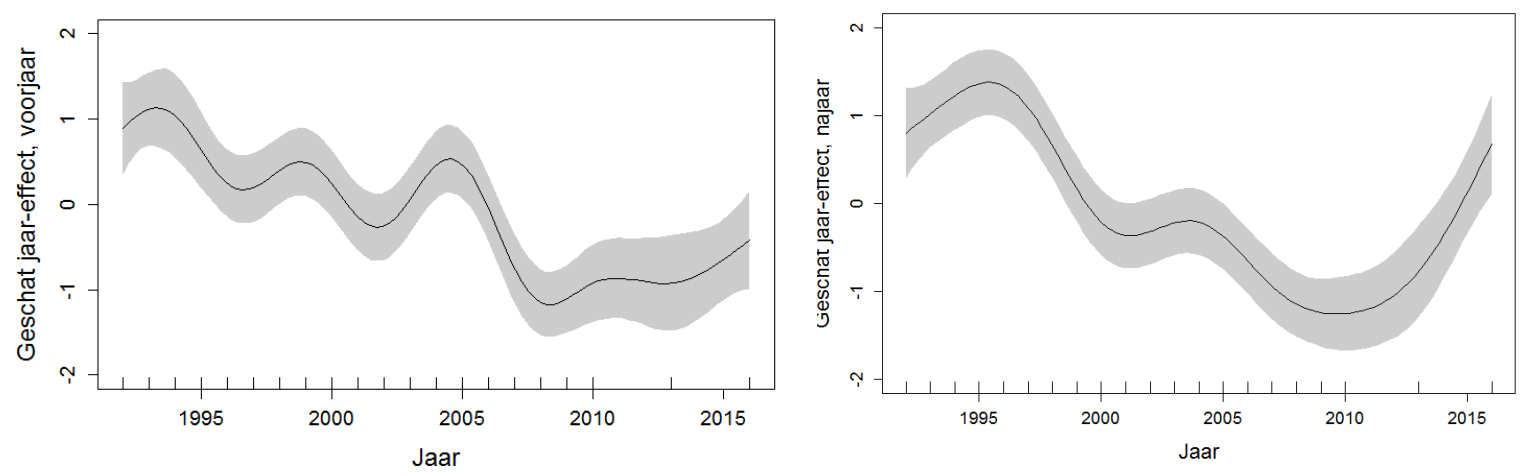

Figuur 49. Het geschatte effect van jaar op de vierdemachtswortel-getransformeerde dichtheid $\left(\# / \mathrm{m}^{2}\right)$ van filtrerende organismen in het voor- (links) en najaar (rechts) in de periode 1992 tot 2016. De getrokken lijn geeft het resultaat van het GAMM model (Model_5) over alle data. Het grijze gebied geeft het 95\%betrouwbaarheidsinterval weer.

Het GAMM-model geeft ook aan dat waterdiepte een significant effect heeft op dichtheid $(p<0.001)$. In ondiep water is de dichtheid laag maar neemt significant toe tot een waterdiepte van 5-6 m onder NAP. Vanaf 5-6 m neemt de dichtheid weer significant af tot ongeveer $12 \mathrm{~m}$ onder NAP waar het betrouwbaarheidsinterval toeneemt.

\section{Biomassa}

Uit de GAMM-analyse blijkt dat Model_6, waar het jaar effect varieert met het deelgebied, de meeste variatie in de data verklaart. Figuur 50 geeft de trend weer voor het westelijke (links) en oostelijke (rechts) deel van het Grevelingenmeer welke is berekend door het model (Model_6) op basis van de vierdemachtswortel-getransformeerde biomassa ( $y$-as). Het GAMM model toont significante trends $(p<0.001)$ van biomassa in de tijd in beide deelgebieden (Figuur 50$)$.

Beide trends zijn op dezelfde schaal geplot waardoor het verschil tussen deelgebieden direct kan worden vergeleken. De vorm van de trend is relatief gelijk van af 1995 welke een significant dalende biomassa laat zien tot 2008-2009. De biomassa neemt in 2013 weer significant toe. Het verschil in biomassa ligt voornamelijk tussen 1992 en 1995 met een hogere biomassa in het westelijke deel van het Grevelingenmeer. De gemiddelde biomassa verschilt niet per deelgebied of seizoen $(p>0.050)$. 

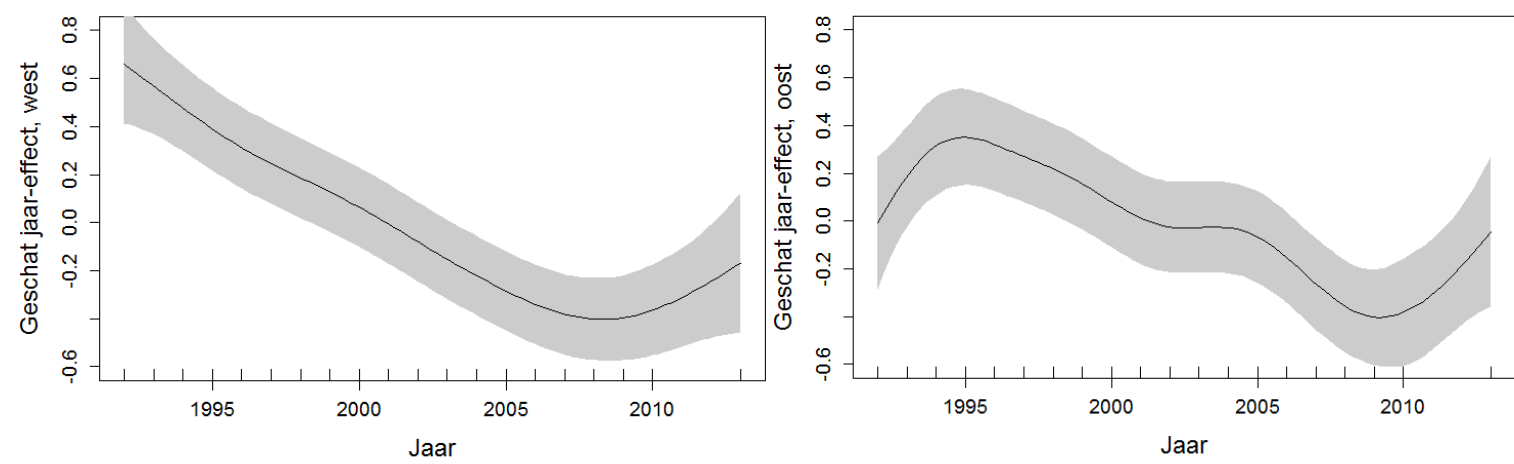

Figuur 50. Het geschatte effect van jaar op de vierdemachtswortel-getransformeerde biomassa $\left(\mathrm{g} / \mathrm{m}^{2}\right)$ van filtrerende organismen in het westelijke (links) en oostelijke (rechts) deel van het Grevelingenmeer in de periode 1992 tot 2013. De getrokken lijn geeft het resultaat van het GAMM model (Model_6) over alle data. Het grijze gebied geeft het 95\%-betrouwbaarheidsinterval weer.

In het westelijke deel was het muiltje (Crepidula fornicata) verantwoordelijk voor de hoge biomassa in 1992 met op bepaalde stations een biomassa tot $614 \mathrm{~g} / \mathrm{m}^{2}$. Na de significante afname van biomassa zorgden voornamelijk het muiltje $\left(168 \mathrm{~g} / \mathrm{m}^{2}\right.$ ), de Amerikaanse zwaardschede (Ensis leei, $152 \mathrm{~g} / \mathrm{m}^{2}$ ) en de Japanse oester (Magallana gigas, $101-135 \mathrm{~g} / \mathrm{m}^{2}$ ) voor een verhoogde biomassa in 2013. In het oostelijke deel zorgden het muiltje en de platte oester (Ostrea edulis) voor een stijging in biomassa in 1995 met in bepaalde stations een biomassa van 203-425 g/ $\mathrm{m}^{2}$. De stijging in 2013 werd voornamelijk veroorzaakt door het muiltje, de Japanse oester en de strandgaper (Mya arenaria, 420 $\left.\mathrm{g} / \mathrm{m}^{2}\right)$.

Het GAMM-model geeft ook aan dat waterdiepte een significant effect heeft op de biomassa $(p<0.001)$. In ondiep water is de biomassa laag maar neemt significant toe tot een waterdiepte van 5 $6 \mathrm{~m}$ onder NAP. Vanaf 5-6 m neemt de biomassa weer significant af tot ongeveer $15 \mathrm{~m}$ onder NAP waar het betrouwbaarheidsinterval toeneemt. 


\subsubsection{Verworming}

Schaub et al. (2002) suggereren dat het Grevelingenmeer minder gunstig is geworden voor soorten die voedsel uit het water filtreren. Door de afsluiting van het gebied zakt zwevend materiaal eerder naar de bodem waarvan bodemetende organismen kunnen profiteren (Schaub et al. 2002). Vanaf 1990 blijkt de verhouding van de wormen ten opzichte van de weekdieren toe te nemen waardoor er sprake zou zijn van een zogenaamde 'verworming' van het systeem (Schaub et al. 2002). Het voortzetten van die trend werd gesignaleerd door Wetsteijn (2011) tot 2008 en bevestigd door de huidige aanvulling van de MWTL-monitoringsreeks tot 2016. Door dezelfde berekening uit te voeren als in voorgaande rapporten blijkt dat de verhouding van de wormen ten opzichte van de weekdieren nog steeds significant toeneemt $\left(y=0.922 x-1767, p<0.001, R^{2}=0.44\right.$, Figuur 51). Uitgedrukt in biomassa wordt voor deze periode geen significante trend gevonden $(y=0.231 x-453, p=0.09$, $\left.\mathrm{R}^{2}=0.05\right)$.

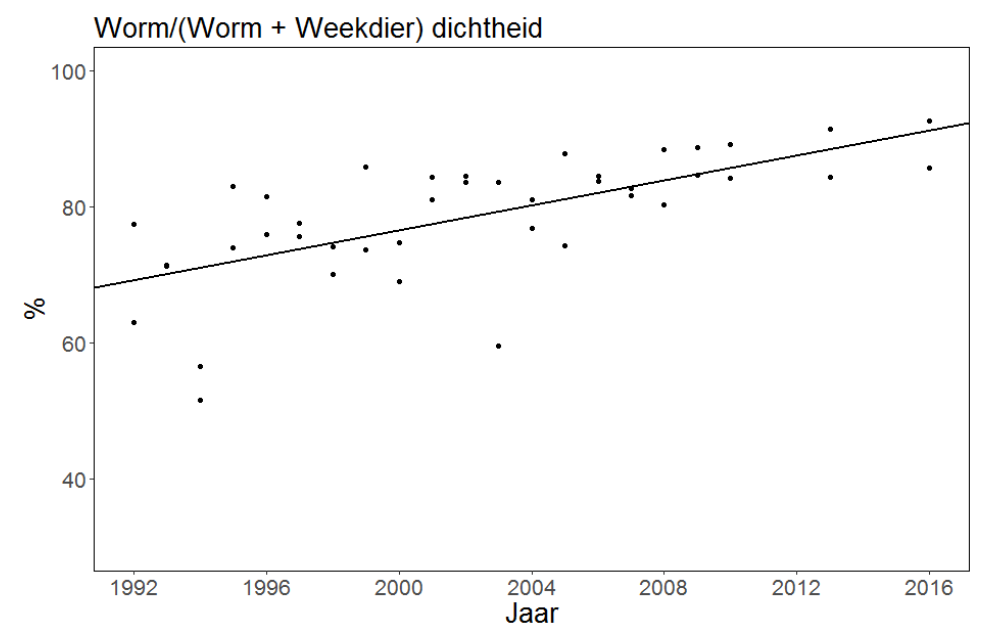

Figuur 51. 'Verworming' in het Grevelingenmeer in de periode 1992-2016 uitgedrukt in de ratio worm/(worm +weekdier) dichtheid voor de periode 1992-2016 met gegevens in het oostelijk en westelijk deel samengenomen. 


\subsubsection{Sediment}

\subsubsection{Mediane korrelgrootte}

In het Grevelingenmeer lijkt de mediane korrelgrootte in zowel het westelijke als oostelijke deel niet veel te zijn veranderd tussen 1999 en 2016. De variatie omtrent de mediane korrelgrootte schijnt echter wel wat minder te zijn geworden met het verloop van de jaren (Figuur 52).

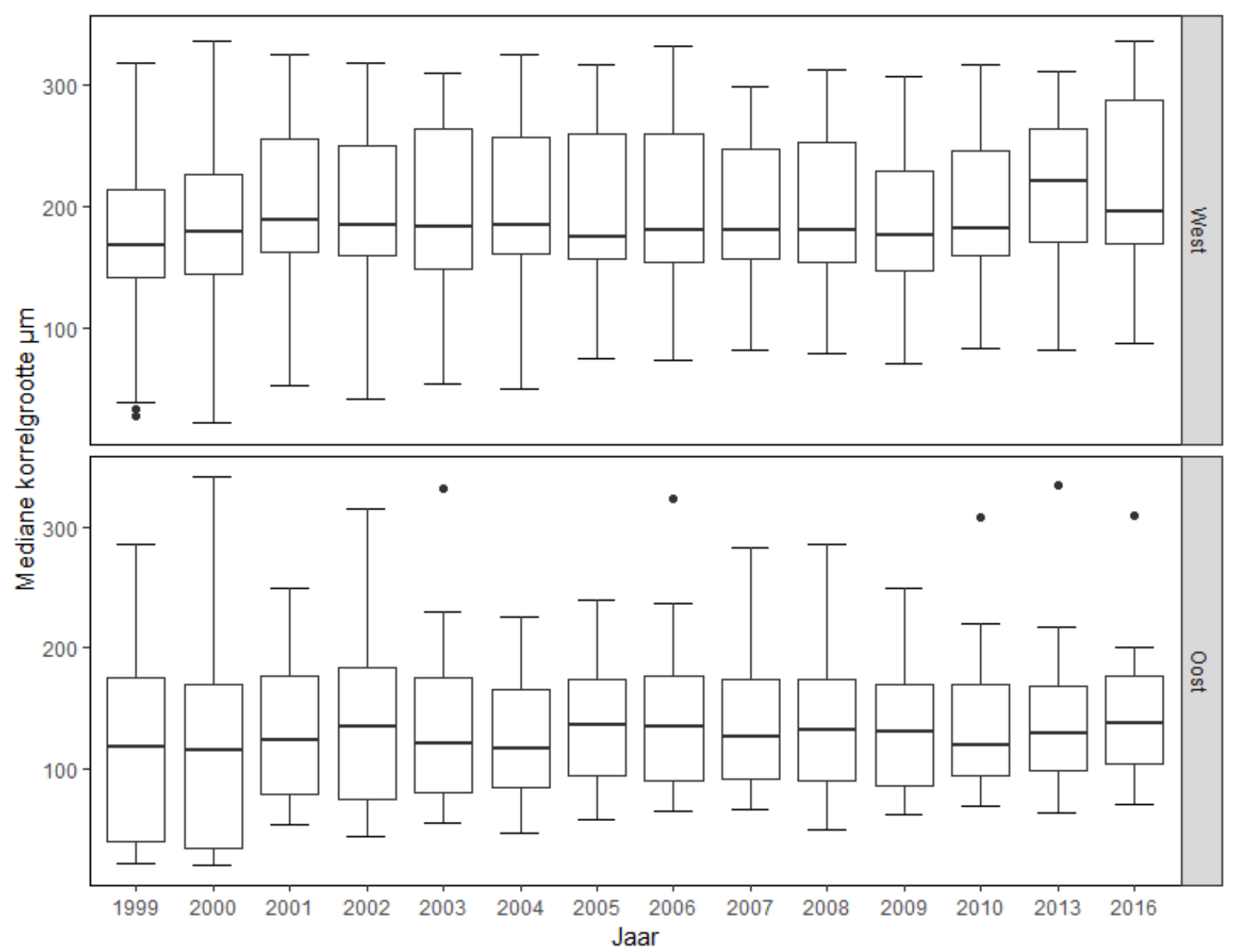

Figuur 52. Boxplot van de mediane korrelgrootte $(\mu \mathrm{m})$ voor de verschillende jaren (1999-2010) in de twee verschillende deelgebieden (west, oost).

Uit de GAM-analyse blijkt dat Model_3 de meeste variatie verklaart in de mediane korrelgrootte. Figuur 52 geeft de gemiddelde mediane korrelgrootte weer per jaar terwijl Figuur 53 de trend weergeeft welke is berekend door het model (Model_3). Het GAM model geeft aan dat er een significante trend is van de mediane korrelgrootte over de tijd $(p<0.001)$ met een lichte toename van 1999 tot 2002 en van 2010 tot 2016. De vorm van de trend verschilt niet per deelgebied en/of seizoen ( $p>0.050$, afwezigheid van interactie tussen verklarende variabelen) maar de gemiddelde mediane korrelgrootte is hoger in het westelijke deel van het Grevelingenmeer in vergelijking met het oostelijke deel $(p<0.001)$. Er is geen verschil in korrelgrootte tussen seizoenen $(p=0.989)$. 


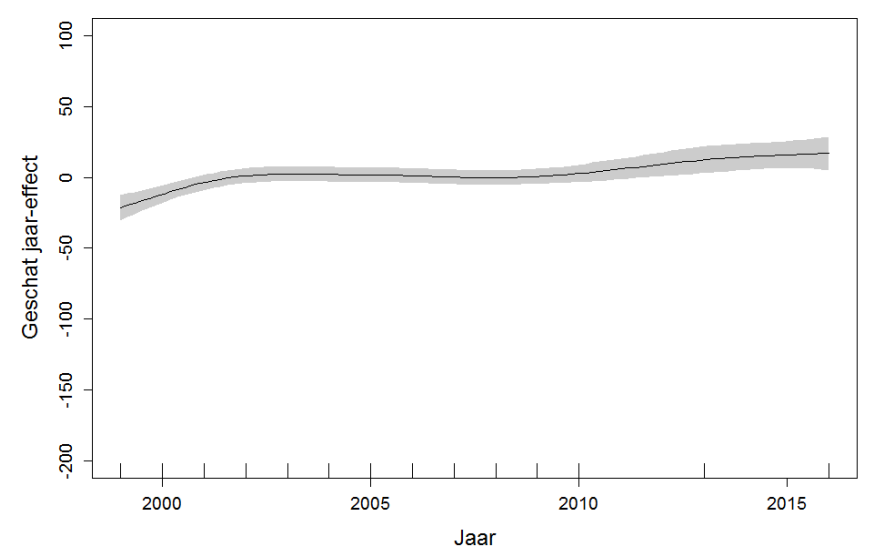

Figuur 53. Het geschatte effect van jaar op de mediane korrelgrootte $(\mu m)$ in de periode 1999-2016. De getrokken lijn geeft het resultaat van het GAM model (Model_3) weer over alle data. Het grijze gebied geeft het $95 \%$ - betrouwbaarheidsinterval weer.

Het GAM-model geeft ook aan dat waterdiepte ( $x$-as) een significant effect heeft op korrelgrootte ( $y$ as) $(p<0.001)$, alhoewel de vorm van de trend verschilt per deelgebied (Figuur 54$)$. Beide trends zijn op dezelfde schaalt geplot waardoor het verschil tussen deelgebieden direct kan worden vergeleken. In het westelijke deel is de mediane korrelgrootte laag in heel ondiep water maar neemt significant toe tot een waterdiepte van ongeveer 2.5 meter onder NAP. Tot ongeveer 8 meter onder NAP blijft de korrelgrootte relatief hoog waarna het significant afneemt tot een diepte van ongeveer $12 \mathrm{~m}$ en dan constant blijft. In het oostelijke deel is de relatie tussen diepte en korrelgrootte iets anders met de grootste mediane korrelgrootte in het ondiepe water (tot 2 meter) waarna de grootte significant afneemt tot een waterdiepte van ongeveer $8 \mathrm{~m}$ onder NAP waarna het laag blijft tot $15 \mathrm{~m}$ waar het betrouwbaarheidsinterval toeneemt door een combinatie van het geringe aantal monsters dat zijn genomen op deze diepte en waarschijnlijk de grote variatie tussen deze monsters.
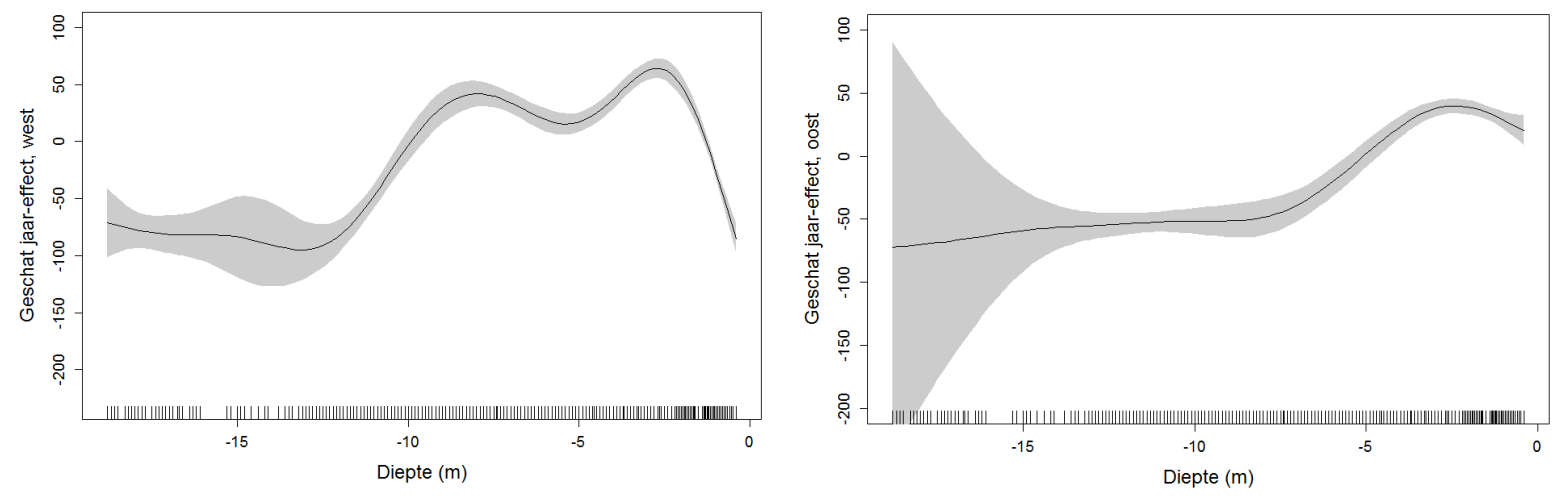

Figuur 54. Het geschatte effect van jaar op de mediane korrelgrootte $(\mu m)$ in het westelijk (links) en oostelijk (rechts) deel van het Grevelingenmeer in de periode 1999-2016. De getrokken lijn geeft het resultaat van het GAM model weer over alle data. Het grijze gebied geeft het 95\%- betrouwbaarheidsinterval weer. 


\subsubsection{Slibgehalte}

Naast de mediane korrelgrootte is er ook gekeken naar het slibgehalte (Figuur 55) dat ook een belangrijke rol speelt in de aanwezigheid van bodemdieren. Het slibgehalte is in het algemeen wat hoger in het oostelijke deel in vergelijking met het westelijke deel van het Grevelingenmeer maar neemt over het algemeen wat af in de periode 1999-2016.

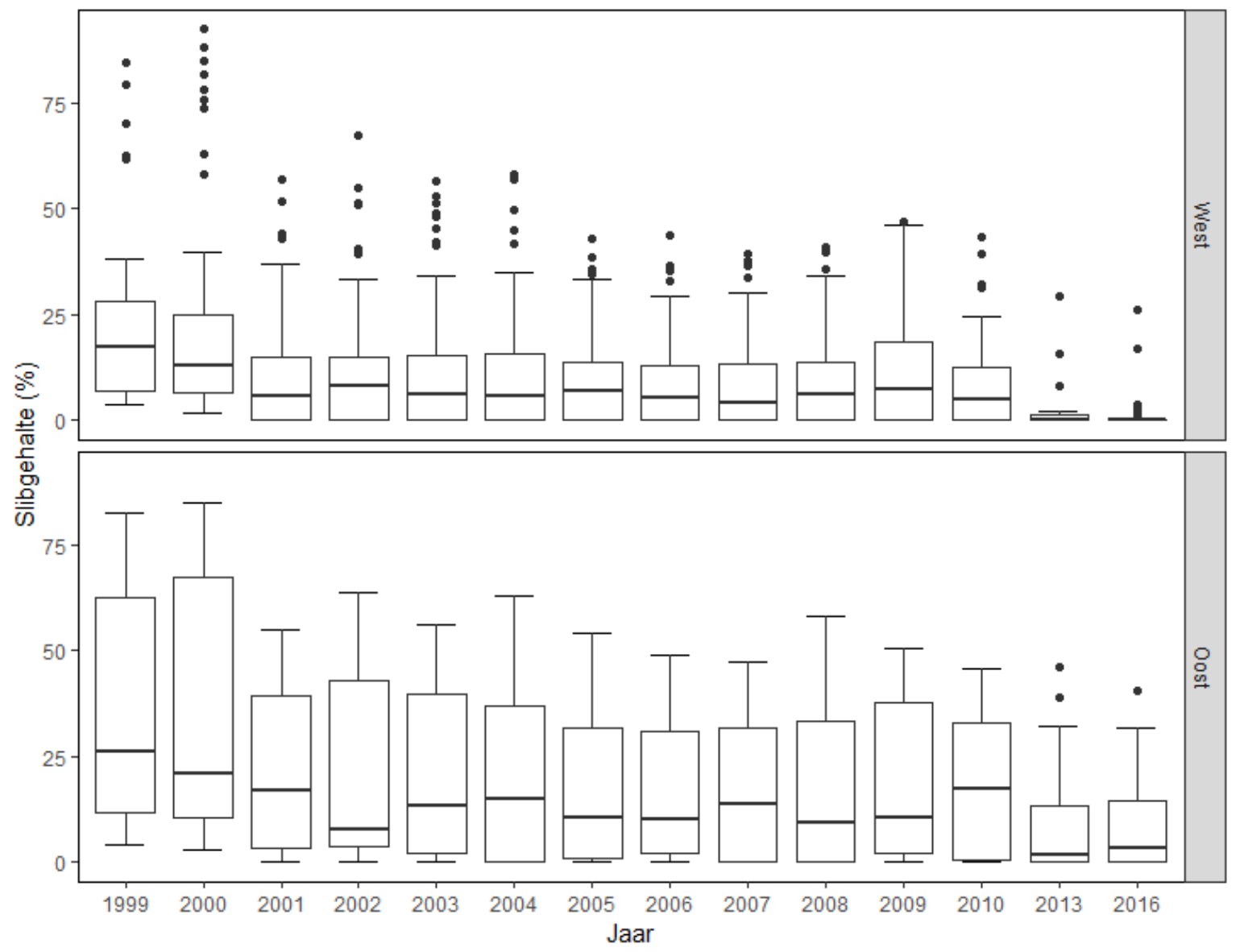

Figuur 55. Boxplot van het slibgehalte (\%) voor de verschillende jaren (1999-2010) in de twee verschillende deelgebieden (west, oost). 


\subsection{Verschuiving van bodemgemeenschap}

\subsubsection{Basis resultaten van de MDS op basis van de soorten dichtheden}

Een MDS uitgevoerd op basis van de dichtheden voor de 96 geselecteerde taxa (Frequentie van voorkomen $>1 \%$ ) in 252 monsters resulteert in een plaatje waar locaties en taxa gezamenlijk geplaatst kunnen worden (Figuur 56a) met een redelijk niveau van kwaliteit (Stresswaarde=0.170). Voor deze MDS was het wel nodig om gebruik te maken van drie dimensies om tot een oplossing te komen; het gros van de variatie is wel opgevangen door de twee eerste assen MDS1 en MDS2. De plaatsing van de locaties t.o.v. elkaar op de MDS-plot ("Ordination Distance") toont een goede overeenkomst $\left(r^{2}=0.970\right)$ met de onderlinge verschillen berekend d.m.v. de Bray-Curtis coëfficiënt (Figuur 56b).
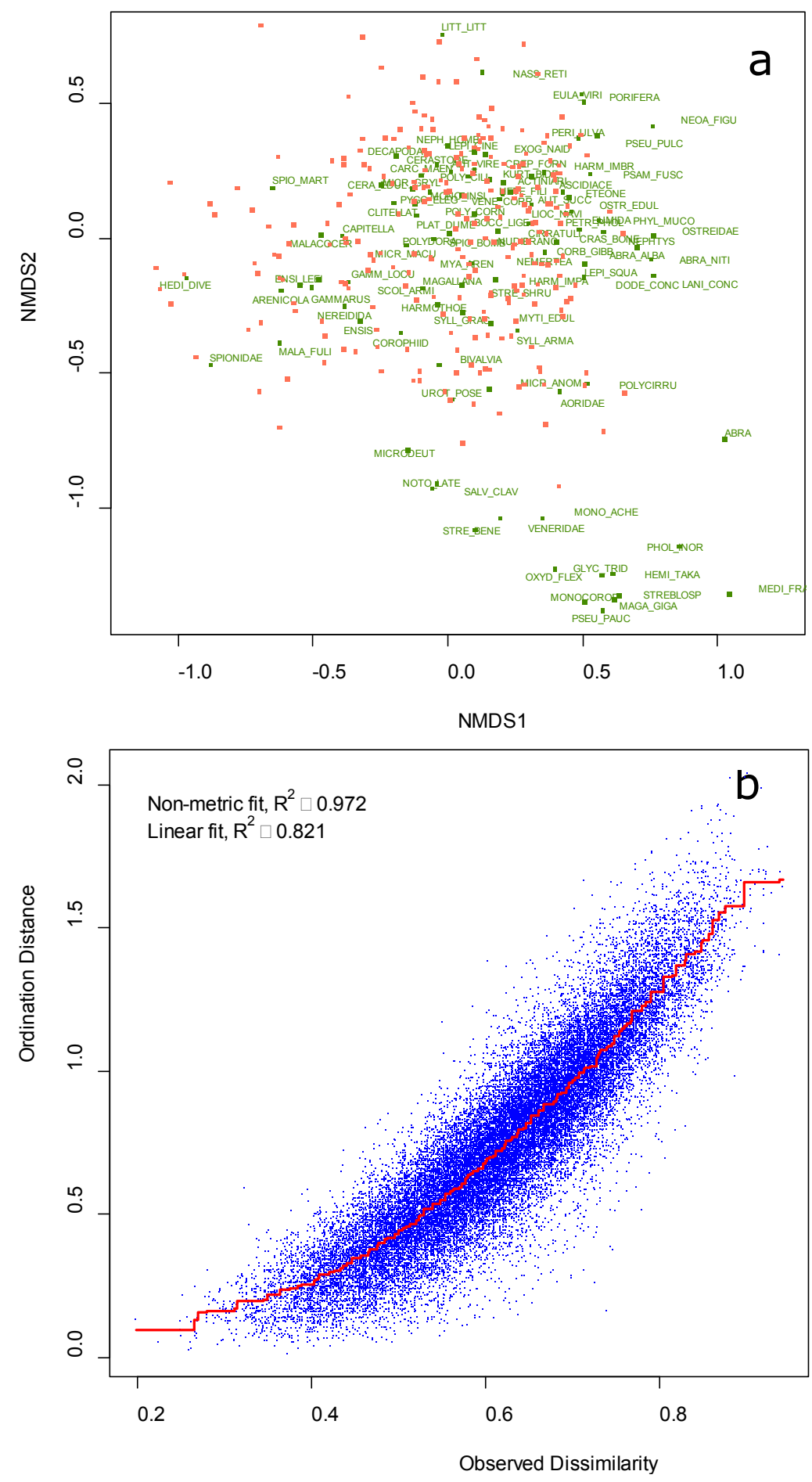
Figuur 56. a: MDS plot met weergave van de relatieve posities van monsters (rode vierkanten) en taxa (groene tekst). b: MDS stressplot met de afstand tussen alle locatie koppels in de MDS-plot als functie van het verschil berekend d.m.v. de Bray-Curtis coëfficiënt.

\subsubsection{Relatie met omgevingsfactoren}

De Envfit() routine ( $R$, package vegan) detecteert vooral sterke overeenkomsten tussen de verschillen in de gemeenschapssamenstelling en hun indeling $m$.b.t. het jaartal en de dieptestratum en veel minder met het deelgebied en/of het seizoen waarin de monsters genomen zijn (Tabel 6).

Tabel 6. Correlatie $\left(r^{2}\right)$ tussen omgevingsfactoren en de MDS ordinatie van de monsters op basis van de dichtheid aan bodemdierentaxa.

\begin{tabular}{|l|c|}
\hline Factoren & $\mathbf{r}^{\mathbf{2}}$ (Envfit) \\
\hline Jaar & 0.427 \\
\hline stratum & 0.304 \\
\hline deelgebied & 0.062 \\
\hline Seizoen & 0.003 \\
\hline
\end{tabular}

Een tweede Envfit() routine uitgevoerd op de factor jaar met onderscheid van het dieptestratum resulteert in een correlatie van $r^{2}=0.790$ met de ordinatie. De centroïden per jaar berekend uit deze tweede analyse als de gemiddelde scores per jaar binnen elk stratum laten parallelle verschuivingen zien tussen opeenvolgende jaren langs de tweede as van de ordinatie (MDS2) waar het ondiepste strata zich duidelijk onderscheidt van de twee diepere strata langs MDS1 (Figuur 57).

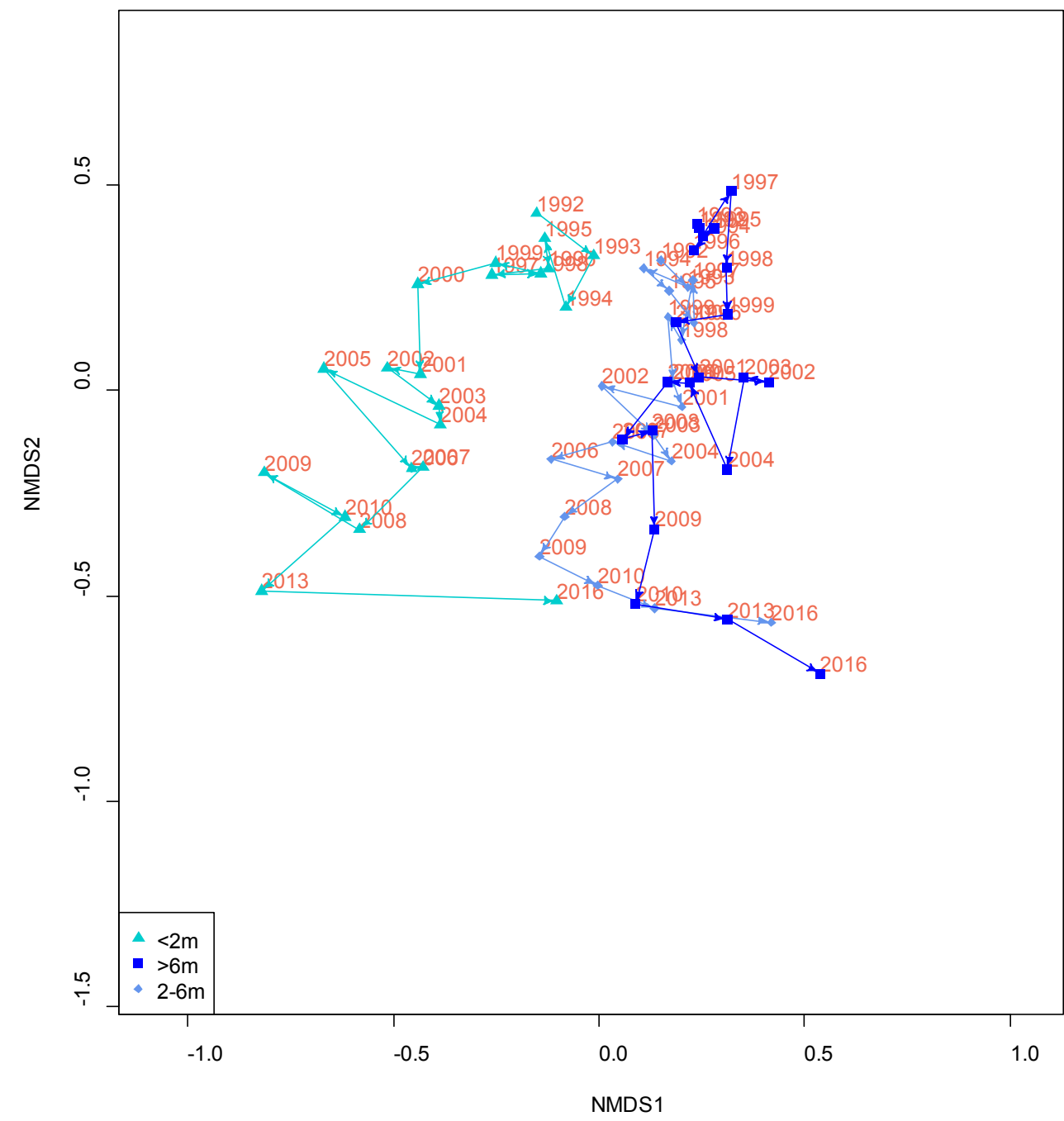

Figuur 57. MDS plot met weergave van jaar-centroïden binnen elk dieptestratum. Opeenvolgende jaren (tussen 1992 en 2016) zijn verbonden met pijlen.

Figuur 57 toont een eenduidige ontwikkeling in de bodemdierengemeenschap die zich heeft doorgezet over de laatste 21 jaar in alle dieptestrata, wel met behoud van een structureel verschil tussen het 
ondiepe stratum t.o.v. de twee diepere strata. Het plaatje verkregen op basis van de tweede en derde assen NMDS3/NMDS2 (Bijlage: Tabel 11) wijkt nauwelijks af van dat in Figuur 57.

Wanneer de samenstelling van de bodemdiergemeenschap gelijk is tussen twee jaren dan vallen de punten (jaren) in Figuur 57 op elkaar zoals het geval is in 2006 en 2007 in de diepte strata $<2$ m. Verschilt de samenstelling echter tussen jaren dan worden de punten in deze analyse verder uit elkaar gezet (bijv. 2008 en 2009). Hoe groter de afstand tussen de punten, hoe groter het verschil is in de samenstelling van de bodemdiergemeenschappen. De samenstelling is bijvoorbeeld veranderd in 2000 ten opzichte van de periode 1992-1999 waar de punten vrij dicht op elkaar liggen (Figuur 57). Daarnaast laat Figuur 57 zien dat de samenstelling van de bodemdieren in de ondiepe zone (0-2 m) verschilt van dat van de twee diepere strata waar de samenstelling meer overeen komt. De bodemdiergemeenschap ontwikkelt zich nog steeds in alle strata en de ontwikkeling vindt ook plaats in dezelfde richting. Het is niet zo dat gemeenschappen zich verschillend ontwikkelen op bepaalde dieptes.

\subsubsection{Verschillen tussen groepen op basis van omgevingsfactoren}

De verschillen in bodemdiergemeenschappen in relatie tot de omgevingsfactoren periode, seizoen en stratum zijn weergegeven in Figuur 58 m.b.v. de 80\% betrouwbaarheidsellipsen berekend voor elke niveau binnen elke factor.
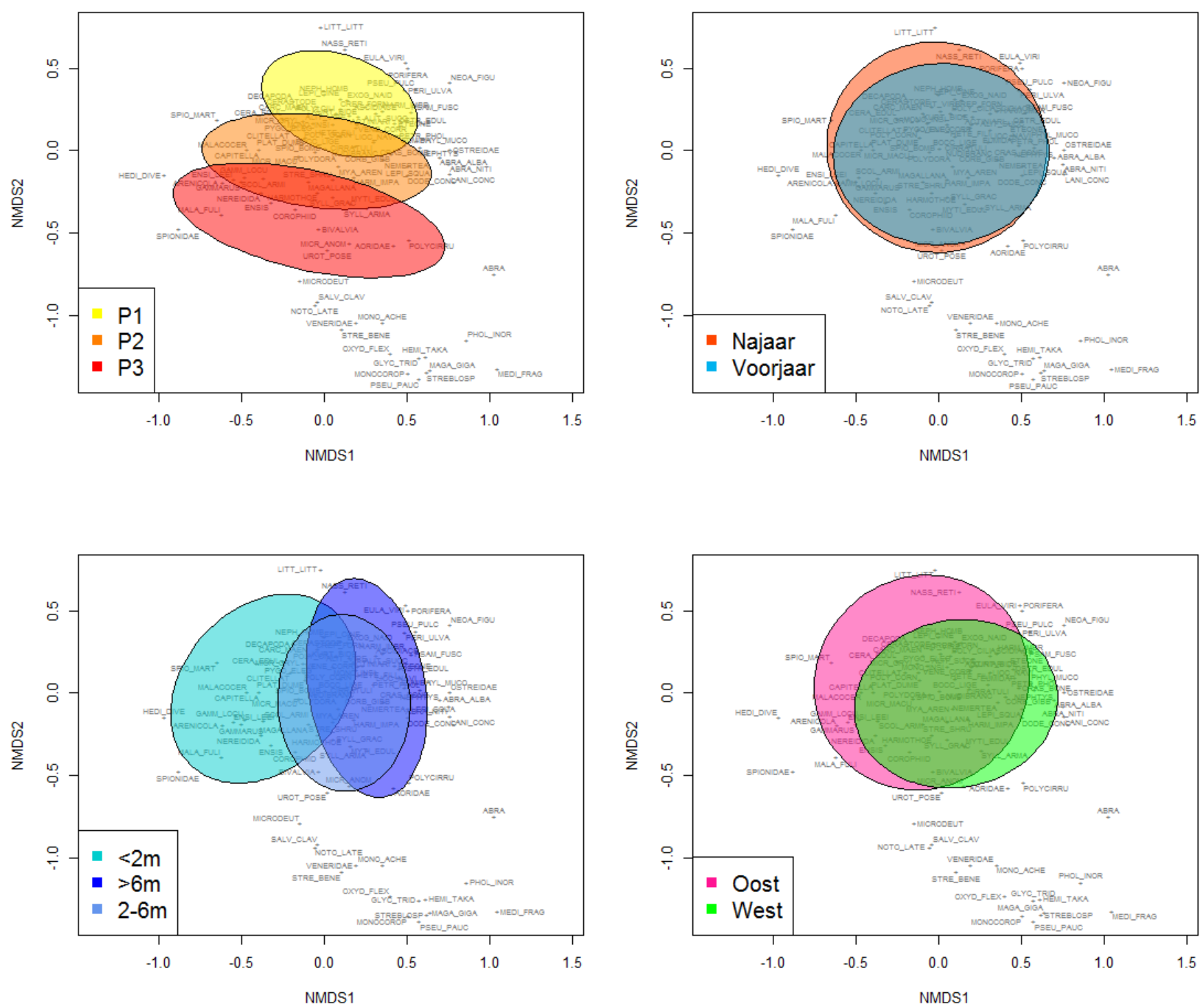

Figuur 58. MDS plot met weergave van de $80 \%$ betrouwbaarheidsellipsen op basis van (v.l.n.r.) perioden, seizoen, diepte strata en deelgebieden. 
De verschillen tussen niveaus binnen elke omgevingsfactor zijn getoetst met de r-statistiek berekend d.m.v. een ANOSIM (Tabel 7). Door middel van ellipsen (Figuur 58) wordt aangegeven in hoeverre de soortensamenstelling gelijk is tussen bijvoorbeeld deelgebieden, seizoenen, dieptestrata en perioden. Hoe groter de overlap tussen twee ellipsen, hoe meer de soortensamenstelling gelijk is. R-waarden geven aan hoe groepen van elkaar verschillen waarbij een waarde groter dan 0.50 aangeeft dat er een beduidend verschil is tussen bijvoorbeeld deelgebieden of seizoenen (Clarke en Gorley 2001). De samenstelling tussen het voor- en najaar is vrij klein terwijl de samenstelling tussen de verschillende perioden groter is (minder overlap) (Figuur 58). De ANOSIM wijst op de afwezigheid van significant verschil tussen de deelgebieden (west, oost) en seizoenen (voorjaar, najaar) met r-waarden kleiner dan 0.100. Tussen de perioden en dieptestrata zijn er wel significante verschillen waargenomen.

Tabel 7. $R$ waarden bij de vergelijkingen tussen de niveaus van omgevingsfactoren berekend m.b.v. ANOSIM voor de bodemdieren gemeenschappen

\begin{tabular}{|l|l|l|}
\hline & $P 1$ & $P 2$ \\
\hline$P 1$ & & \\
\hline$P 2$ & 0.39 & \\
\hline$P 3$ & 0.70 & 0.27 \\
\hline
\end{tabular}

\begin{tabular}{|l|l|l|}
\hline & $<2 m$ & $2-6 m$ \\
\hline$<2 m$ & & \\
\hline $2-6 m$ & 0.48 & \\
\hline$>6 m$ & 0.44 & 0.56 \\
\hline
\end{tabular}

\begin{tabular}{|l|l|}
\hline & Oost \\
\hline Oost & \\
\hline West & 0.09 \\
\hline
\end{tabular}

\begin{tabular}{|l|l|}
\hline & Najaar \\
\hline Najaar & \\
\hline Voorjaar & 0.08 \\
\hline
\end{tabular}

\subsubsection{Bijdrage van individuele taxa aan de wargenomen verschillen}

De SIMPER-routine levert een lijst van taxa die verantwoordelijk zijn voor het onderscheiden van de monsters op de MDS-plot o.b.v. hun indeling in de verschillende klassen van omgevingsfactoren. Met het oog op de bondigheid wordt de beschouwing hier beperkt tot de vergelijkingen tussen de dieptestrata $<2 \mathrm{~m}$ en $>6 \mathrm{~m}$ en de perioden P1 en P3.

Dieptestrata: De volgende taxa $(\mathrm{N}=22)$ zijn de belangrijkste voor de verschillen in bodemdiergemeenschappen van de dieptestrata $<2 \mathrm{~m}$ en $>6 \mathrm{~m}$. Van die 22 taxa tonen de volgende zeven hogere dichtheden in het diepe dan in het ondiepe: Corbula gibba (tweekleppige, "korfschelp"), Microdeutopus anomalus (vlokreeft), Syllidia armata (Borstelworm), Cirratulidae (Borstelworm), Alitta succinea (borstelworm, "ambergele zeeduizenpoot"), Heteromastus filiformis (borstelworm), en Actiniaria (bloemdieren).

De volgende zes taxa komen met hogere dichtheden voor in het ondiepe dan in het diepe: Spio martinensis (borstelworm), Hediste diversicolor (borstelworm, "veelkleurige duizendpoot"), Arenicola (borstelworm, "wadpier"), Capitella (borstelworm, "slangpier"), Platynereis dumerilii (borstelworm) en Microdeutopus gryllotalpa (vlokreeft).

Perioden: De volgende taxa $(\mathrm{N}=25)$ zijn de belangrijkste voor de verschillen in bodemdiergemeenschappen tussen de perioden P1 en P3. Deze taxa kenmerken zich door een relatief sterke toename in dichtheid tussen deze twee perioden: Microdeutopus anomalus (vlokreeft), Notomastus latericeus (borstelworm), Corophiidae (vlokreeft), Syllidia armata (borstelworm), Arenicola (borstelworm, "zeepier"), Scoloplos armiger (borstelworm), Capitella (borstelworm, "slangpier").

De volgende 9 taxa kenmerken zich door relatief sterk afname in dichtheid tussen P1 en P3: Tritia reticulata (slakdier,"Gevlochten fuikhoren", Pygospio elegans (borstelworm, "zandpijp"), Exogone naidina (borstelworm), Nephtys hombergii (borstelworm, "zandzager"), Monocorophium insidiosum (vlokreeft), Polydora ciliata (borstelworm, "Slikkokkerworm"), Crepidula fornicata (slakdier, "Muiltje"), Kurtiella bidentata (tweekleppige, "Tweetandschelpje"), Microdeutopus gryllotalpa (vlokreeft). 


\subsection{Vergelijking met het Veerse meer}

Het Veerse Meer werd net als het Grevelingenmeer afgesloten van de Noordzee en de Oosterschelde waardoor het tot een brakwatermeer ontwikkelde. In 2004 werd een doorlaatmiddel (Katse Heule) in gebruik genomen om de uitwisseling tussen het Veerse meer en de Oosterschelde te vergroten en daarmee de negatieve effecten van de massieve polderwaterafvoeren zoals fluctuerende zoutgehaltes en eutrofiëring te verminderen. Dit is vergelijkbaar met het Grevelingenmeer waar ook de sterk dalende zoutgehaltes na de sluiting van de Brouwersdam (1971) en de bedreiging van de zoutwatergemeenschappen geleid hebben tot de ingebruikname van de Brouwersluis in 1978 met aanpassingen in beheer tegen gelaagdheid en zuurstofloosheid in de diepe waterlagen in 1980 (winterverversing) en 1999 (permanente uitwisseling). Door de vergelijkbare problematieken kan de ervaring opgedaan in het Veerse meer relevant zijn voor het Grevelingenmeer.

Tussen 1990 en 2003 was de macrofauna (MWTL-monitoring) in de diepere waterlagen in het Veerse meer aan het afsterven en vele soorten in de ondiepere strata waren letterlijk gedecimeerd (Escaravage \& Hummel, 2003). Vlak voor de ingebruikname van het doorlaatmiddel waren de zuurstofconcentraties laag en een explosieve bloei van voor schelpdieren niet eetbaar picoplankton ging gepaard met de massale sterfte van strandgapers en een versnelde algemene verarming van de bodemdierengemeenschappen (Craeymeersch \& De Vries 2007).

Na de ingebruikname van het doorlaatmiddel kreeg het Veerse Meer een meer marien karakter met een verhoging van het zoutgehalte. De vermindering van de gelaagdheid en de hiermee gerelateerde zuurstofloosheid in de diepe waterlagen bleef wel beperkt tot het oostelijke gebied, dicht bij het doorlaatmiddel. Het groeiende mariene karakter van het Veerse meer werd gekenmerkt door een verhoging van de soortendiversiteit op het harde substraat met de opkomsten van b.v. Japans bessenwier, Japanse oester en verschillende zakpijp-soorten (Prins et al. 2015).

De eerste twee jaren na de ingebruikname van het doorlaatmiddel werden gekenmerkt door een spectaculair herstel m.b.t. het aantal soorten en de biomassa aan schelpdieren, mosselen, strandgapers en kokkels (Craeymeersch \& De Vries 2007). Dit herstel was echter van korte duur met een afname in de bodemdierenbiomassa en van het soortenaantal waargenomen in 2013 ten opzichte van eerdere jaren (Prins et al. 2015).

Naast de afname in biomassa van strandgapers en kokkels vond in de laatste jaren ook een toename in de biomassa van wadpieren plaats waaruit blijkt dat de bodemdierengemeenschap nog steeds in een fase van aanpassing is aan de nieuwe omstandigheden (Prins et al. 2015). Op basis van de "Veerse meer studie" gerapporteerd door Prins et al. (2015) komen de volgende punten naar voren om in beschouwing te nemen voor de "Grevelingen studie":

- De veranderingen in de bodemdierengemeenschappen na de ingebruikname van het doorlaatmiddel zijn niet eenduidig en strekken zich uit over perioden van jaren; de waarnemingen ervan vragen om een monitoring met een adequate beschrijving van de jaartot-jaarvariatie én van de lange-termijntrends.

- De verandering in de frequentie van monitoring van bodemdieren van het zachte substraat van jaarlijks naar eens in de drie jaar (sinds 2010), zorgt ervoor dat het alleen op langere termijn ( $>10$ jaar) mogelijk zal zijn om trends in de samenstelling van de bodemdierengemeenschap te detecteren.

- De verandering van bemonsteringsoppervlak van 0,02 $\mathrm{m}^{2}$ naar 0,08 $\mathrm{m}^{2}$ sinds 2013 maakt het niet mogelijk om waarnemingen van soortensamenstelling en wellicht zelfs biomassa voor en na 2013 direct te vergelijken. Zo'n vergelijking vraagt om een correctie voor de verhoogde trefkans van de 'zeldzamere' (mogelijk met hogere biomassa) soorten.

- De gemeenschappen van hard substraat tonen een snelle opkomst aan mariene soorten en maken ontwikkelingen mee die meer eenduidig lijken te zijn dan bij de waarnemingen van de bodemdieren van het zachte substraat. 


\section{Conclusies}

- De analyses in dit rapport laten zien dat, bijna vijftig jaar na afsluiting van het Grevelingenmeer, de bodemdiergemeenschap nog steeds in ontwikkeling is. De gemeenschap blijft veranderen over de geanalyseerde periode (1992-2016).

- De biomassa in het Grevelingenmeer neemt sinds 1992 significant af tot ongeveer 2008 waarna de biomassa in 2013 weer wat toeneemt. De komende jaren zullen moeten uitwijzen of deze trend zich doorzet. Daarnaast ligt de biomassa gemiddeld hoger in het westelijk deel van het Grevelingenmeer en fluctueert daar ook sterker dan in het oostelijk deel. Het oostelijk deel lijkt stabieler te zijn en biomassa neemt daar voor bepaalde phyla ook minder sterk af. De biomassa in het Grevelingenmeer wordt voornamelijk gedomineerd door één enkele soort: het muiltje (Crepidula fornicata). Deze neemt wel significant af in de loop der tijd (aandeel: $64 \%$ in 1993 en $29 \%$ in 2010) en wordt deels vervangen (aandeel: $0 \%$ in 1993 en $31 \%$ in 2010) door de Japanse oester (Magallana gigas). Filtrerende soorten domineren de biomassa, en bodemetende (deposit feeders) soorten de dichtheid in het Grevelingenmeer.

- $\quad$ De gemiddelde dichtheid neemt significant af in de periode van 1994 tot 2008. De variatie in dichtheden tussen jaren worden voornamelijk veroorzaakt door de seizoenen en in mindere mate door de deelgebieden. Daarnaast is de dichtheid gemiddeld hoger in zowel het voorjaar als in het westelijk deel van het Grevelingenmeer.

- $\quad$ De analyses laten een duidelijke trend zien van biomassa en dichtheid over de diepte met: i een lagere biomassa en dichtheid in de ondiepe zone, ii - een optimum biomassa en dichtheid rond de 4-6 m onder NAP en, iii - een afname van de biomassa en dichtheid naar de diepte toe (toename onzekerheid van de resultaten met diepte door afname van het aantal monsterpunten).

- Verhoudingsgewijs neemt het relatieve aandeel wormen toe, maar dat komt omdat het relatieve aandeel schelpdieren afneemt. De term 'verworming' is daarom wat ons betreft onjuist omdat het aandeel schelpdieren afneemt. 


\section{Discussie en aanbevelingen}

\subsection{Ontwikkeling bodemdiergemeenschap 1992-2016}

\section{Verandering in de tijd}

Het algemene beeld van het macrozoöbenthos in het Grevelingenmeer is dat, bijna vijftig jaar na afsluiting van het Grevelingenmeer, de bodemdiergemeenschappen van het zachte substraat nog steeds in ontwikkeling zijn, waarbij vooral de biomassa een dalende trend laat zien sinds het begin van de MWTL bemonsteringen in 1992. Met het permanent openstellen van de spuisluis in de Brouwersdam in 1999 werd verwacht dat de stratificatie en zuurstofloosheid zich in de diepe putten in het Grevelingenmeer gedeeltelijk op zouden heffen. Al eerder is echter vastgesteld dat de verandering in het spuiregime geen of zelfs negatieve gevolgen heeft gehad voor de zuurstofconcentraties (Wetsteijn 2011). Vóór 1999 werd de stratificatie in de diepe putten voornamelijk bepaald door een verschil in temperatuur aangezien het verschil in zoutgehalte tussen de oppervlaktelaag en de diepe laag heel gering was (1-2 g chloride per liter). Na het permanent openzetten van de spuisluis wordt gedurende de zomer relatief warm, zout Noordzeewater ingelaten. Dit water is zouter en zuurstofrijker en zakt daarom naar de bodem van de put van Scharendijke. Het zuurstofarme water in de put van Scharendijke wordt door het ingelaten water over de ondiepe delen verder oostelijk het Grevelingenmeer ingeduwd (Wetsteijn 2011). Als gevolg van dit mechanisme is de diepte waarop zuurstofloosheid optreedt in de vakken 1 en 2 (vakindeling: Figuur 7 in Wetsteijn 2011) nauwelijks veranderd, maar heeft in de ondiepere vakken 3 tot 6 na de verandering in het spuibeheer zelfs dieptes tussen 5 en 10 m bereikt (Wetsteijn 2011). Ook al verbetert de situatie in vakken 1 en 2, de bodemdieren kunnen hier niet van profiteren omdat het zich afspeelt op dieptes waar geen of nauwelijks bodemdieren voorkomen (Wetsteijn 2011). Wij hebben niet gekeken naar de relatie tussen bodemdieren en zuurstofloosheid maar er is bekend dat optredende zuurstofloosheid als gevolg van stratificatie negatieve gevolgen kan hebben op de waterkwaliteit en het bodemleven in het Grevelingmeer (Lengkeek et al. 2007; Didderen et al. 2013).

Eerder is door Schaub et al. (2002) gesuggereerd dat de afname in biomassa gerelateerd zou kunnen zijn aan de afsluiting van het gebied, in 1971. Hierdoor is er minder verversing en waterbeweging en zakt het zwevend materiaal (incl. plankton) eerder naar de bodem waardoor filtrerende soorten er niet van kunnen profiteren (Schaub et al. 2002). De biomassa van het macrozoöbenthos wordt in grote mate bepaald door filtrerende soorten zoals het muiltje (Crepidula fornicata). Het voorkomen van het muiltje is daarom ook zeer bepalend voor de trend in biomassa. Het muiltje is sterk afgenomen in biomassa, maar deels door een andere filter feeder, de Japanse oester (Magallana gigas) vervangen. Het Grevelingenmeer is echter al meer dan 40 jaar afgesloten en de vraag is of dit effect nog steeds invloed kan hebben op de bodemdiergemeenschap of dat andere factoren hier een belangrijke rol spelen. De resultaten in dit rapport laten ook zien dat biomassa en dichtheden zowel in de ondiepe delen als diepere delen afnemen dus de afname zal niet alleen gerelateerd zijn aan de zuurstofloosheid. Net als in andere bekkens zoals de Westerschelde, Oosterschelde en Veerse Meer domineren filtrerende soorten de biomassa, en bodemetende (deposit feeders) soorten de dichtheid in het Grevelingenmeer. Hierop vormt het Grevelingenmeer dus geen uitzondering.

De totale biomassa varieert soms sterk tussen opeenvolgende jaren. In weinig dynamische milieus, zoals het Grevelingenmeer, neemt de kans op stratificatie toe. Stratificatie ontstaat doordat waterlagen verschillende dichtheden hebben als gevolg van verschillen in temperatuur en/of saliniteit. De gelaagdheid van de waterkolom minimaliseert de uitwisseling van bijvoorbeeld zuurstof tussen de twee watermassa's, wat kan leiden tot anoxia in de onderste waterlaag waardoor de fauna in de bodem afsterft (Lengkeek et al. 2007). Dit fenomeen treedt nu reeds op in het Grevelingenmeer en heeft in een aantal jaren geleid tot massale sterfte onder oesters op de commerciële oesterpercelen in het Grevelingenmeer (Holland 1991, Peperzak 2002, Peperzak \& Holland 1997). Wetsteijn (2011) heeft een chronologisch overzicht gegeven van de jaren waarin grote oestersterfte optrad. 
Bijvoorbeeld, in de zomer van 2005 en 2006 zou naar schatting 30\% en 60-90\%, respectievelijk, van alle oesters op de percelen in het Grevelingenmeer verloren zijn gegaan. De vermoedelijke oorzaak was zuurstofgebrek als gevolg van de vrij warme voorzomer en het extreem warme weer in 2006. Hierdoor kwamen grote hoeveelheden zeesla boven drijven welke met de volgende regenbui weer naar de bodem zakten. Het gevolg was dat het rottende materiaal oesters en andere levende organismen verstikten (www.divepost.nl; artikel van 12 augustus, Provinciale Zeeuwse Courant, 11 augustus 2006). Alhoewel de oesterpercelen niet overlappen met de MWTL-monsterpunten liggen ze wel dicht bij elkaar (Figuur 3 in Smaal \& Wijsman 2014) en lijkt het erop dat in jaren van grote oestersterfte op de percelen (o.a. 1996, 1997, 2001, 2005, 2006), de biomassa van mollusca (weekdieren) ook afneemt (Figuur 28). Het verdwijnen van grote hoeveelheden weekdieren kan de totale biomassa omlaag brengen aangezien deze groep een belangrijke bijdrage levert ( $83 \%$ ) aan de totale biomassa. Vervolg onderzoek zou moeten uitwijzen of er daadwerkelijk een link is en of dit een verklaring zou kunnen voor de grote fluctuaties van biomassa in de tijd.

\section{Verschillen oostelijk en westelijk deel}

Daarnaast verschilt de trend per deelgebied waarbij de biomassa sterker fluctueert en gemiddeld hoger ligt in het westelijk deel van het Grevelingenmeer. Mogelijk is de biomassa in het westelijk deel hoger en dynamischer door de verversing van het water via de Brouwerssluis en zijn verblijftijden in het oostelijk deel langer.

\section{Verandering over de diepte}

In de ondiepe vooroever is de biomassa relatief laag en neemt significant toe tot een diepte van ongeveer 5 meter onder NAP (optimum). Daarna neemt de biomassa weer significant af tot ongeveer $15 \mathrm{~m}$ waarna het betrouwbaarheidsinterval toeneemt door het beperkt aantal metingen in de diepe zone. De reden van het verloop van de trend in biomassa over de diepte is niet eenduidig te geven. Aannemelijk is dat de lagere biomassa in de ondiepte zone (0-2 $\mathrm{m}$ diepte) wordt veroorzaakt door de hydrodynamiek van golven die vestiging en voorkomen van soorten belemmeren doordat ze worden weggespoeld (Barton en Carter 1982, Weatherhead \& James 2001). Het optimum dat ongeveer op 5 $\mathrm{m}$ onder NAP ligt en de afname van biomassa bij grotere diepte kan verschillende redenen hebben en roept ook weer nieuwe vragen op:

- Door stratificatie, waar waterlagen verschillen in dichtheden als gevolg van verschillen in temperatuur en/of saliniteit, vindt er nauwelijks uitwisseling plaatsvindt tussen de onderste en bovenste waterlaag. Daardoor ontstaan zuurstofarme of zuurstofloze condities doordat zuurstof wordt verbruikt maar niet wordt aangevuld. Naast zuurstof is er ook maar beperkte uitwisseling van andere stoffen mogelijk zoals nutriënten. De volgende processen hangen met elkaar samen en kunnen een verklaring zijn voor een lagere biomassa van bodemdieren naarmate de diepte toeneemt:

- Door stratificatie ontstaat nutriënten deficiëntie waardoor er geen/beperkte primaire productie optreedt waardoor: (1) er geen voedsel meer is voor grazers/filter feeders en (2) er geen zuurstof meer wordt geproduceerd waardoor de zuurstofconcentratie afneemt hetgeen negatieve gevolgen heeft voor bodemdieren.

- Door uitzakken van organisch materiaal uit de bovenste waterlaag domineren afbraakprocessen in de onderste waterlaag waardoor zuurstof wordt geconsumeerd. Als gevolg van stratificatie wordt er geen zuurstof aangevoerd waardoor zuurstof deficiëntie wordt versterkt hetgeen negatieve gevolgen heeft voor bodemdieren.

- Door verschillen in sedimentsamenstelling die mogelijk het bodemleven beïnvloeden, zandiger in de ondiepe delen en toename van de slibfractie en organisch materiaal naarmate de diepte toeneemt als gevolg van bezinking. Mogelijk domineren in de diepere delen afbraakprocessen van organisch materiaal. Door aanwezigheid van lage zuurstof concentraties en afbraakproducten kunnen alleen enkele wormen soorten voorkomen en is dit milieu ongeschikt voor voorkomen van schelpdieren die de grootste biomassa vertegenwoordigen.

Wij hebben ook gekeken naar de relatie biomassa en diepte over de tijd. Er zijn geen grote significante verschuivingen waarneembaar wanneer de studieperiode in stukken van 5 of 10 jaar worden onderverdeeld. De optimale biomassa blijft liggen op ongeveer $5 \mathrm{~m}$ onder NAP met een afname naar diepere en ondiepere delen. Eveneens is gekeken of de biomassa alleen afneemt in 
bepaalde diepte strata. Analyses toonden aan dat biomassa in alle diepte strata significant over de tijd afneemt zoals aangegeven in paragraaf 4.3.1.

\section{Verworming}

Voorgaande rapporten gaven aan dat de verhouding van de wormen ten opzichte van de weekdieren toeneemt waardoor er sprake zou zijn van een 'verworming' van het systeem (Schaub et al. 2002, Wetsteijn 2011). Het voortzetten van die trend werd gesignaleerd door Wetsteijn (2011) tot 2008 en bevestigd door de huidige aanvulling van de MWTL-monitoringsreeks tot 2016. Echter, verhoudingsgewijs neemt het relatieve aandeel wormen wel toe, maar dat komt omdat het relatieve aandeel schelpdieren afneemt. De afname van schelpdieren is zelfs te herleiden tot de afname van één soort: Crepidula fornicata (het muiltje). Het muiltje is zo dominant aanwezig dat de afname van deze soort direct merkbaar is in verschuivingen op gemeenschapsniveau. De term 'verworming' is daarom wat ons betreft onjuist.

\subsection{Beperkingen van dit onderzoek}

- $\quad$ Na 2010 is de jaarlijkse macrozoöbenthosmonitoring van het MWTL-programma teruggeschroefd naar $1 \times$ per jaar. Hierdoor is de trend over de laatste zeven jaar (2010 2016) slechts gebaseerd op drie meetpunten.

- Wisseling in de methodiek (vooral bemonsteringsoppervlakte) en uitvoerende partij van de monitoring heeft mogelijk invloed op de data, met name wat betreft soortenrijkdom, maar mogelijk ook op dichtheid/biomassa. Dit dient nader geëvalueerd te worden. Zie ook vergelijking met Veerse Meer waar hetzelfde speelt.

- Door het ontbreken van een groot aantal biomassabepalingen in de MTWL 2016 dataset konden die gegevens niet meegenomen worden in de analyses betreft biomassa.

- De MWTL meetpunten liggen over het algemeen op plekken waar de zuurstofloosheid niet (of maar voor korte perioden) optreedt. Nader onderzoek is nodig om zuurstofloosheid direct te kunnen koppelen aan de MWTL meetpunten.

- Verbanden met andere veranderingen in het Grevelingenmeer moeten nog geanalyseerd worden, als onderdeel van de integratie binnen de systeemrapportage Grevelingen.

\subsection{Aanbevelingen en vervolg}

Voorliggend rapport is het resultaat van een eerste analyse naar de ontwikkelingen van het macrozoöbenthos in het Grevelingenmeer en kon uitgevoerd worden dankzij steun van LNV, Staatsbosbeheer en eigen investering van WMR. Het vormt een waardevolle stap in het beter begrijpen van de ecologische veranderingen in het meer met bodemdieren als cruciale schakel tussen primaire productie en hogere trofische niveaus. De resultaten laten zien dat de bodemdiergemeenschappen nog steeds in verandering zijn. Vervolgonderzoek zou zich kunnen richten op:

- Nadere analyse naar mogelijke verbanden tussen verschuivingen in de bodemdiergemeenschappen in relatie tot bv. waterbeheer van o.a. de Brouwerssluis en Flakkeese Spuisluis, waterkwaliteitsparameters zoals chlorofyl, doorzicht, zuurstofconcentratie etc., veranderingen in sedimentsamenstelling (bv. slib, organische fractie) etc. Hiermee kan gezocht worden naar mogelijke verklaringen voor veranderingen zoals afname van de biomassa over de tijd. Daarbij kan ook onderzocht worden of veranderingen in omgevingsfactoren relateren aan specifieke trofische groepen of andere functionele kenmerken (zogen. trait-based analysis).

- Historische analyses die verder terug gaan dan 1990 om inzicht te geven in de veranderingen in de eerste decennia na de afsluiting en daarvoor. Dit geeft inzicht in oorspronkelijke gemeenschappen en hoe deze zijn veranderd door de aanleg van Deltawerken waardoor veranderingen in de geanalyseerde periode vanaf 1990 mogelijk beter begrepen kunnen worden en er een beter totaalbeeld ontstaat. 
- Nadere verkenning naar het muiltje als dominante soort: vestiging, verspreiding, ontwikkeling, voedselbron voor andere soorten, competitie met andere soorten en biologie van dit dier. Dit zou meer inzicht kunnen geven in waarom het muiltje zo succesvol is in het Grevelingenmeer en interessant daarbij is ook de vergelijking met de ontwikkeling in andere Deltawateren. Daarnaast is ook de opkomst van de Japanse Oester interessant om nader te bestuderen.

- Naast uitvoeren van vervolganalysen zou het waardevol zijn om gericht aanvullende bodemdierbemonsteringen uit te voeren in zowel de diepe delen waar in de zomer zuurstofloosheid optreedt, om de relatie met het voorkomen van bodemleven te onderzoeken, als in de zeer ondiepe delen tot 1 meter waterdiepte waar in de toekomst mogelijk intergetijdengebied zal ontstaan om een beeld te krijgen van de huidige bodemdiersamenstelling en mogelijke toekomstige ontwikkeling bij getij. Beide gebieden ontbreken nu in de MWTL bemonstering.

- Rijkswaterstaat, Staatsbosbeheer en kennisinstituten Deltares en Wageningen Marine Research hebben de ambitie om de systeemkennis van het Grevelingenmeer te verbeteren door het ontwikkelen van een digitale systeemrapportage (als vervolg op eerdere bekkenrapportages). Het doel is om alle beschikbare gegevens van het Grevelingenmeer m.b.t. fysische parameters, waterkwaliteit, flora en fauna (zowel terrestrische als aquatisch) te analyseren, en onderlinge relaties/verklaring voor veranderingen nader te onderzoeken en autonome ontwikkeling in te schatten en toegankelijk beschikbaar te maken in een digitale omgeving waarvoor in 2018 een eerste start is gemaakt. Dit onderzoek vormt een waardevolle eerste stap voor het uitwerken van het ecologische deel van de systeemrapportage. Een eerste volgende stap zou zijn om (delen van) dit rapport online beschikbaar te maken in de digitale omgeving en aanvullende analysen (zie eerder) uit te voeren om beter grip te krijgen systeem functioneren en hoe onderlinge parameters met elkaar samen hangen. 


\section{$7 \quad$ Kwaliteitsborging}

Wageningen Marine Research beschikt over een ISO 9001:2015 gecertificeerd kwaliteitsmanagementsysteem. Dit certificaat is geldig tot 15 december 2021. De organisatie is gecertificeerd sinds 27 februari 2001. De certificering is uitgevoerd door DNV GL.

De kwaliteit van de analysemethoden wordt op verschillende manieren gewaarborgd. De juistheid van de analysemethoden wordt regelmatig getoetst door deelname aan ringonderzoeken waaronder die georganiseerd door QUASIMEME. Indien geen ringonderzoek voorhanden is, wordt een tweede lijnscontrole uitgevoerd. Tevens wordt bij iedere meetserie een eerstelijnscontrole uitgevoerd. Naast de lijnscontroles wordende volgende algemene kwaliteitscontroles uitgevoerd:

- Blanco onderzoek.

- Terugvinding (recovery).

- Interne standaard voor borging opwerkmethode.

- Injectie standard.

- Gevoeligheid.

Bovenstaande controles staan beschreven in Wageningen Marine Research werkvoorschrift ISW 2.10.2.105.

Indien gewenst kunnen gegevens met betrekking tot de prestatiekenmerken van de analysemethoden bij het chemisch laboratorium worden opgevraagd.

Indien sprake is van onbeheerste kwaliteit worden passende maatregelen genomen. 


\section{Literatuur}

Arcadis (2013) De ontwikkelingen van het macrobenthos in het Grevelingenmeer. Rapport nummer: C03041.003067.0100. 99p

Bannink, B. A., J. H. M. Van der Meulen en P. H. Nienhuis (1984) Lake Grevelingen: from an estuary to a saline lake. An introduction. Netherlands Journal of Sea Research 18: 179-190.

Barton, D.R., J.C.H. Carter (1982) Shallow-water epilithic invertebrate communities of eastern Georgian bay, Ontario, in relation to exposure to wave action. Canadian Journal of Zoology, 60: 984-993.

Clarke, K.R. \& R.N. Gorley (2001) PRIMER v5: User manual/tutorial. PRIMER-E, Plymouth, UK, 91 pp.

Clarke, K.R. \& R.M. Warwick (2001) Change in Marine Communities: An Approach to Statistical Analysis and Interpretation. 2nd Edition, PRIMER-E, Ltd., Plymouth Marine Laboratory, Plymouth.

Craeymeersch, J.A., E.B.M. Brummelhuis, W. Sistermans \& E.C. Stikvoort (1992) Het macrobenthos van de Westerschelde, de Oosterschelde, het Veerse Meer en het Grevelingenmeer. Najaar 1990. Rapportage in het kader van het Biologisch Monitoring Programma. NIOO-CEMO, Yerseke.

Craeymeersch, J.A.M. \& I. De Vries (2007) Waterkwaliteit en ecologie Veerse Meer: het tij is gekeerd. Eerste evaluatie van de veranderingen na de ingebruikname van de 'Katse Heule'.

Rijksinstituut voor Kust en Zee (RWS RIKZ), Middelburg, RIKZ/2007.008, 86 pp.

Didderen, K., W. Lengkeek, S. Bouma (2013) De verspreiding van witte bacteriematten en schade aan het bodemleven in het Grevelingenmeer III. Bureau Waardenburg bv. Rapport nr. 13-147.

Escaravage, V., H. Hummel, D. Blok, A. Dekker, A. Engelberts, O. van Hoesel, L. Kleine Schaars, R. Markusse, T. Meliefste, W. Sistermans, S. Wijnhoven (2009) Macrozoöbenthosonderzoek MWTL in de Delta 2009. NIOO-CEME 2011. RWS rapportnummer: BM12.08. 107 pp.

Escaravage, V. \& H. Hummel (2003) Macrobenthos Dynamiek Veerse Meer (Periode 1990-2003). $77 \mathrm{pp}$.

Feddes, Y., Y. van Boheemen, S. Jensen, R. Balk (2018) Ontwikkelingsperspectief Ecologische Grote Wateren, $40 \mathrm{p}$.

Grevelingenmeer, V. (2010) Visplan Grevelingenmeer, Rapport, 108 pagina's.

Hoeksema, H.J. (2002) Grevelingenmeer van kwetsbaar naar weerbaar? Een beschrijving van de ontwikkelingen van 1996 tot 2001 en een toetsing aan het beleid. Rapport RIKZ/2002.033, $60 p$.

Holland, A.M.B. (1991) Waterbeheer Grevelingenmeer 1980-1990. Nota GWWS-91.086, 76p.

Kater, B. J. \& E. Van Onselen (2013) De ontwikkelingen van het macrobenthos in het Grevelingenmeer. Arcadis, Zwolle.

Leewis, L., E. C. Verduin \& J. Wanink (2015) Macrozoöbenthosonderzoek in de zoute Rijkswateren, Jaarrapportage MWTL 2013 Waterlichamen: Delta (Oosterschelde, Westerschelde, Grevelingenmeer, Veerse Meer). Grontmij, Amsterdam.

Legendre P., L. Legendre (1998) Numerical ecology, 2nd English edn. Elsevier, Amsterdam.

Lengkeek, W., S. Bouma, H.W. Waardenburg (2007) Het effect van zuurstofdeficiëntie op het bodemleven in het Grevelingenmeer. Een blik onder water. Bureau Waardenburg bv. Rapport nr. 07-186.

Nolte, A., T. Troost, G. de Boer, C. Spiteri, B. van Wesenbeeck (2008) Verkenning oplossingsrichtingen voor een betere waterkwaliteit en ecologische toestand van het Grevelingenmeer. Deltares, $133 \mathrm{p}$.

Oksanen, J., F.G. Blanchet, M. Friendly, R. Kindt, P. Legendre, D. McGlinn, P.R. Minchin, R.B. O'Hare, G.L. Simpson, P. Solymos, M.H.H. Stevens, E. Szoecs \& H. Wagner (2019) Vegan: Community Ecology Package. R package version 2.5-4. https://CRAN.R-project.org/package=vegan.

Peperzak, L. 2002. Plaagalgen in het Grevelingenmeer. MONISNEL document zonder nummer, 19 p.

Peperzak, L., \& A.M.B. Holland (1997) Sterfte van oesters en het voorkomen van een nieuwe plaagalg in het Grevelingenmeer in de jaren 1996 en 1997. Werkdocument RIKZ/OS97.862x.

Pinheiro, J., D. Bates, S. DebRoy, D. Sarkar \& R Core Team (2018) nlme: Linear and Nonlinear Mixed 
Effect Models. R package version 3.1-137, <URL: https://CRAN.Rproject.org/package $=$ nlme $>$.

Prins, T.C. en S.A. Vergouwen (red.) (2015) Bekkenrapport Veerse Meer 2000-2014, ten behoeve van evaluatie peilbesluit. Deltares Rapport 1220248-000-ZKS-0010: 134 pp.

R Core Team (2018) R: A language and environment for statistical computing. R Foundation for statistical computing. Vienna, Austria, https://www.r-project.org/.

Reise, K. (2002) Sediment mediated species interactions in coastal waters. Journal of Sea Research, 48: 127-141.

Rijkswaterstaat (2013) Peilbesluit Grevelingenmeer.

Schaub, B.E.M., D. van Oevelen, W.C.H. Sistermans, M. Rietveld, P.M.J. Hummel \& H.H. Hummel (2002) Veranderingen in de samenstelling van het macrobenthos van de Grevelingen (periode 1990-2000) en de mogelijke oorzaken. NIOO-CEME rapport 2002-01, Yerseke.

Sistermans, W.C.H., H. Hummel, M.A. Bergmeijer, D. Blok, A.G.M. Engelberts, L. de Witte-Dek, A. Dekker, O.J.A. van Hoesel, L. Kleine Schaars, M.M. Markusse (2009) Het macrobenthos van de Westerschelde, de Oosterschelde, het Veerse Meer en het Grevelingenmeer in het voor- en najaar van 2008. Rapportage in het kader van het Biologisch Monitoring Programma. Rapport Monitor Taakgroep, NIOO-CEME, Yerseke, 107 p.

Smaal, A.C., W.M. Wijsman (2014) Kansen voor schelpdiercultuur in Grevelingen en VolkerakZoommeer bij ander waterbeheer. Wageningen Marine Research UR (University \& Research Centre), Wageningen Marine Research rapportnummer C045/14, $32 \mathrm{blz}$.

Tangelder, M., Janssen, J., Nolte, A. Walles, B., Wijsman, J., Ysebaert, T. (2018) Scenariostudie natuurperspectief Grevelingenmeer. Wageningen Marine Research Wageningen UR (University \& Research Centre), Wageningen Marine Research rapportnummer C021/18, $164 \mathrm{blz}$.

Van de Haterd, R. J. W., W. Lengkeek, S. Bouma \& M. T. Collombon (2010) Herintroductie getij in de Grevelingen en effecten op natuur in intergetijdengebieden. Bureau Waardenburg, Culemborg. 10-079:75.

Visser, J. (1995) Het Grevelingenmeer, natuurlijk ingericht. Achtergronden van 25 jaar inrichting en beheer. Min. Verkeer en Waterstaat, Dir IJsselmeergebied, Rapport nummer: 378, 85 pagina's.

Van de Kamer, J.P.G., J.H.M. van der Meulen (1985) De toepassing van waterkwaliteitsmodellen voor het beleid en beheer van het Grevelingenmeer. $\mathrm{H}_{2} \mathrm{O}, 18(4)$ : 78-84.

Van Moorsel, G.W.N.M. (2005) Macrofauna en hydromorfologie van zoute wateren, 2005. Ecosub, Doorn.

Wattel, G. (1996) Grevelingenmeer: uniek maar kwetsbaar. De ontwikkelingen in de periode 19901995. Rapport RIKZ-96.014, 101 p.

Weatherhead, M.A. \& M.R. James (2001) Distribution of macroinvertebrates in relation to physical and biological variables in the littoral zone of nine New Zealand lakes. Hydrobiologia 462: 115129.

Wetsteijn, L.P.M.J. (2011) Grevelingenmeer: meer kwetsbaar. Een beschrijving van de ecologische ontwikkelingen voor de periode 1999 t/m 2008-2010 in vergelijking met de periode $1990 \mathrm{t} / \mathrm{m}$ 1998. Rijkswaterstaat Waterdienst, Lelystad. 163 p.

Wijnhoven, S., Hummel, H. (2009) Historische analyse exoten in de Zeeuwse delta. De opkomst, verspreiding, ontwikkeling en impact van exoten onder de macrofauna van het zachte substraat in de Zeeuwse brakken en zoute wateren. NIOO-CEME, Yerseke, the Netherlands. Monitor Taskforce Publication Series 2009-11, 192 p.

Wijnhoven, S., Duineveld, G., Lavaleye, M., Craeymeersch, J. Troost, K., Van Asch, M. (2013) Kaderrichtlijn Marien indicatoren Noordzee; Naar een uitgebalanceerde selectie van indicator soorten ter evaluatie van habitats en gebieden en scenario's hoe die te monitoren. Monitor Taskforce Publication Series 2013 - 02. NIOZ, Den Hoorn \& Yerseke, Nederland.

Wijsman, J. W. M. (2002) Stratificatie en zuurstofdeficiëntie in het Grevelingenmeer. RIKZ Middelburg, Rapport nummer: RIKZ/AB/2002.819X, 64 p.

W\&B (2012) MIRT Verkenning Grevelingen. Milieueffectrapport. Witteveen \& Bos, Rapport, 55 pagina's. 


\section{Verantwoording}

Rapport C021/19

Projectnummer: 4318100201

Dit rapport is met grote zorgvuldigheid tot stand gekomen. De wetenschappelijke kwaliteit is intern getoetst door een collega-onderzoeker en het verantwoordelijk lid van het managementteam van Wageningen Marine Research

Akkoord:

Dr. J.A.M. Craeymeersch

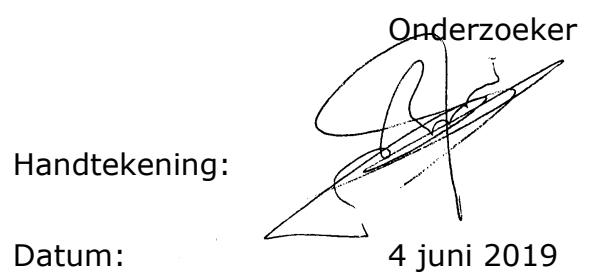

Akkoord:

Dr. J. Asjes

Manager integratie

Handtekening:

Datum:

4 juni 2019 


\section{Bijlage 1 Overzicht veranderingen macrozoöbenthos}

Tabel 8. Gemiddelde biomassa $\left(\mathrm{g} / \mathrm{m}^{2}\right)$ per jaar per phylum in de periode 1992-2013.

\begin{tabular}{|c|c|c|c|c|c|c|c|c|c|c|c|c|}
\hline Jaar & Annelida & Arthropoda & Bryozoa & Chordata & Cnidaria & Echinodermata & Mollusca & Nemertea & Ochrophyta & Phoronida & Platyhelminthes & Porifera \\
\hline 1992 & 6.82 & 2.95 & 0.00 & 2.61 & 0.66 & 0.00 & 55.17 & 0.01 & 0.00 & 0.00 & 0.00 & 0.07 \\
\hline 1993 & 6.05 & 2.15 & 0.00 & 2.56 & 0.46 & 0.29 & 77.16 & 0.00 & 0.00 & 0.00 & 0.00 & 0.26 \\
\hline 1994 & 3.24 & 2.47 & 0.00 & 4.43 & 0.75 & 0.00 & 72.53 & 0.00 & 0.00 & 0.00 & 0.00 & 2.56 \\
\hline 1995 & 5.35 & 2.18 & 0.00 & 0.59 & 0.56 & 1.06 & 61.46 & 0.00 & 0.09 & 0.00 & 0.00 & 0.68 \\
\hline 1996 & 8.44 & 1.60 & 0.00 & 1.99 & 1.76 & 3.14 & 53.10 & 0.01 & 0.02 & 0.00 & 0.00 & 0.08 \\
\hline 1997 & 6.33 & 3.15 & 0.00 & 0.39 & 1.61 & 3.30 & 41.55 & 0.01 & 0.00 & 0.00 & 0.00 & 0.14 \\
\hline 1998 & 5.33 & 0.83 & 0.00 & 1.01 & 0.72 & 0.00 & 54.73 & 0.01 & 0.00 & 0.00 & 0.00 & 0.03 \\
\hline 1999 & 5.03 & 1.29 & 0.00 & 0.98 & 0.02 & 0.00 & 51.46 & 0.01 & 0.01 & 0.00 & 0.00 & 0.00 \\
\hline 2000 & 3.82 & 1.44 & 0.00 & 0.00 & 0.41 & 1.85 & 56.13 & 0.01 & 0.00 & 0.00 & 0.00 & 0.00 \\
\hline 2001 & 3.43 & 2.86 & 0.00 & 0.28 & 0.69 & 0.00 & 39.02 & 0.00 & 0.00 & 0.00 & 0.00 & 0.00 \\
\hline 2002 & 3.68 & 0.62 & 0.00 & 1.10 & 0.09 & 1.85 & 50.82 & 0.00 & 0.00 & 0.00 & 0.00 & 0.00 \\
\hline 2003 & 2.54 & 1.41 & 0.00 & 0.06 & 0.43 & 0.00 & 27.94 & 0.00 & 0.00 & 0.00 & 0.00 & 0.00 \\
\hline 2004 & 4.37 & 2.33 & 0.00 & 0.00 & 0.50 & 0.13 & 33.68 & 0.02 & 0.00 & 0.00 & 0.00 & 0.00 \\
\hline 2005 & 2.67 & 1.65 & 0.00 & 0.09 & 0.17 & 0.00 & 32.30 & 0.01 & 0.00 & 0.00 & 0.00 & 0.00 \\
\hline 2006 & 2.39 & 3.18 & 0.00 & 2.26 & 0.21 & 0.00 & 31.07 & 0.00 & 0.00 & 0.00 & 0.00 & 0.00 \\
\hline 2007 & 1.53 & 0.58 & 0.00 & 0.40 & 0.22 & 0.00 & 29.87 & 0.00 & 0.00 & 0.00 & 0.00 & 0.00 \\
\hline 2008 & 3.83 & 0.51 & 0.00 & 0.48 & 0.23 & 0.27 & 14.37 & 0.00 & 0.00 & 0.00 & 0.00 & 0.16 \\
\hline 2009 & 3.52 & 0.37 & 0.00 & 0.22 & 0.40 & 0.00 & 18.63 & 0.00 & 0.00 & 0.00 & 0.00 & 0.02 \\
\hline 2010 & 4.04 & 3.54 & 0.00 & 0.72 & 0.05 & 0.72 & 39.37 & 0.01 & 0.00 & 0.00 & 0.00 & 0.00 \\
\hline 2013 & 5.97 & 2.83 & 0.00 & 0.00 & 0.53 & 0.00 & 30.00 & 0.02 & 0.00 & 0.00 & 0.00 & 0.00 \\
\hline
\end{tabular}


Tabel 9. Gemiddelde dichtheid per jaar per phylum in de periode 1992-2016.

\begin{tabular}{|c|c|c|c|c|c|c|c|c|c|c|c|c|}
\hline Jaar & Annelida & Arthropoda & Bryozoa & Chordata & Cnidaria & Echinodermata & Mollusca & Nemertea & Ochrophyta & Phoronida & Platyhelminthes & Porifera \\
\hline 1992 & 2839.03 & 477.13 & 0.00 & 26.11 & 33.89 & 0.00 & 1440.65 & 17.82 & 0.00 & 0.00 & 0.00 & 13.61 \\
\hline 1993 & 3122.69 & 439.21 & 0.00 & 15.00 & 29.44 & 0.42 & 1250.28 & 11.81 & 7.78 & 6.11 & 0.00 & 4.44 \\
\hline 1994 & 3124.17 & 634.44 & 0.00 & 68.89 & 18.89 & 0.00 & 2594.17 & 1.94 & 0.00 & 0.00 & 0.00 & 5.28 \\
\hline 1995 & 3418.47 & 809.31 & 0.00 & 6.11 & 15.14 & 1.11 & 990.69 & 5.56 & 5.56 & 0.00 & 0.00 & 8.33 \\
\hline 1996 & 5505.56 & 1623.61 & 0.00 & 40.42 & 43.19 & 0.56 & 1538.19 & 38.19 & 16.11 & 0.00 & 0.00 & 11.67 \\
\hline 1997 & 2770.00 & 493.33 & 0.00 & 8.61 & 33.61 & 1.11 & 863.61 & 30.00 & 0.00 & 0.56 & 0.00 & 1.67 \\
\hline 2000 & 2061.67 & 599.58 & 0.00 & 0.42 & 4.58 & 11.67 & 819.03 & 12.22 & 0.00 & 1.11 & 0.00 & 0.00 \\
\hline 2001 & 2449.31 & 1215.69 & 0.00 & 4.31 & 5.97 & 2.78 & 521.25 & 2.78 & 0.00 & 0.00 & 0.00 & 0.00 \\
\hline 2002 & 1881.67 & 760.00 & 0.00 & 11.67 & 3.47 & 2.78 & 357.08 & 9.31 & 0.00 & 0.00 & 0.00 & 0.00 \\
\hline 2003 & 3491.94 & 1167.78 & 0.00 & 1.11 & 6.39 & 0.56 & 1527.78 & 9.44 & 0.00 & 0.00 & 0.00 & 0.00 \\
\hline 2004 & 4564.58 & 1068.89 & 0.00 & 0.00 & 43.06 & 1.11 & 1263.47 & 70.56 & 0.00 & 1.67 & 5.00 & 0.00 \\
\hline 2008 & 1535.14 & 507.92 & 0.00 & 3.89 & 1.94 & 0.56 & 310.69 & 8.89 & 0.00 & 0.42 & 1.11 & 2.22 \\
\hline 2009 & 1691.67 & 647.22 & 0.00 & 4.44 & 2.22 & 0.00 & 268.06 & 3.89 & 0.00 & 0.00 & 0.00 & 0.83 \\
\hline 2010 & 2374.99 & 911.26 & 0.00 & 27.03 & 74.37 & 1.06 & 374.12 & 12.74 & 0.00 & 0.42 & 0.00 & 0.00 \\
\hline 2013 & 1693.48 & 926.84 & 0.00 & 0.00 & 16.68 & 0.00 & 202.81 & 19.09 & 0.00 & 0.00 & 0.21 & 0.00 \\
\hline 2016 & 3340.10 & 1813.17 & 0.53 & 0.22 & 8.75 & 0.87 & 428.63 & 11.84 & 0.00 & 0.00 & 0.54 & 0.53 \\
\hline
\end{tabular}


Tabel 10. Significantietabel van modellen getest - AIC waarden. Het model welke de meeste variatie in de data verklaarde is dikgedrukt.

\begin{tabular}{|c|c|c|c|c|c|c|c|c|}
\hline & Model_o & Model_1 & Model_2 & Model_3 & Model_4 & Model_5 & Model_6 & Model_7 \\
\hline Totale biomassa & 6804.2 & 6805.8 & 6818.7 & 6813.2 & 6836.9 & 6810.1 & 6804.8 & 6814.0 \\
\hline $\begin{array}{r}\text { Biomassa zonder } C . \\
\text { fornicata }\end{array}$ & 5713.5 & 5714.6 & 5721.4 & 5725.0 & 5736.9 & 5722.3 & 5707.1 & 5724.1 \\
\hline Mollusca & 7596.9 & 7597.8 & 7612.2 & 7605.7 & 7634.6 & 7601.7 & 7597.5 & 7600.0 \\
\hline Annelida & 3624.1 & 3626.1 & 3634.1 & 3630.6 & 3631.5 & 3638.0 & 3614.0 & 3632.0 \\
\hline Arthropoda & 3320.1 & 3318.6 & 3329.9 & 3331.8 & 3342.3 & 3300.7 & 3333.3 & 3324.2 \\
\hline Totale dichtheid & 10967.3 & 10964.8 & 10938.2 & 10978.1 & 10956.1 & 10966.5 & 10978.5 & 11001.4 \\
\hline Mollusca & 10776.1 & 10774.4 & 10772.4 & 10788.5 & 10795.7 & 10756.9 & 10765.7 & 10755.3 \\
\hline Annelida & 10446.4 & 10447.0 & 10412.5 & 10453.0 & 10426.2 & 10450.6 & 10450.5 & 10475.5 \\
\hline Arthropoda & 11505.8 & 11491.0 & 11503.3 & 11520.7 & 11525.2 & 11459.5 & 11515.9 & 11479.9 \\
\hline \multicolumn{9}{|l|}{$\frac{\text { Bodemetende }}{\text { organismen: }}$} \\
\hline Dichtheid & 10467.2 & 10467.7 & 10433.8 & 10474.4 & 10448.0 & 10473.4 & 10462.7 & 10470.0 \\
\hline Biomassa & 2649.5 & 2649.1 & 2651.9 & 2639.8 & 2656.6 & 2623.6 & 2637.8 & 2651.2 \\
\hline \multicolumn{9}{|l|}{$\begin{array}{c}\text { Filtrerende } \\
\text { organismen: }\end{array}$} \\
\hline Dichtheid & 10800.4 & 10799.5 & 10810.7 & 10811.7 & 10834.1 & 10786.1 & 10794.5 & 10792.0 \\
\hline Biomassa & 7687.3 & 7704.7 & 7695.9 & 7727.1 & 7689.7 & 7685.6 & 7687.7 & 7688.7 \\
\hline $\begin{array}{r}\text { Mediane } \\
\text { korrelgrootte }\end{array}$ & 16049.1 & 16051.1 & 16060.1 & 15799.1 & 15820.1 & 16058.1 & 16053.5 & 16059.4 \\
\hline
\end{tabular}


Tabel 11. MDS plot van de derde as versus de eerste as van de MDS met weergave van de $80 \%$ betrouwbaarheidsellipsen op basis van (v.I.n.r.) Perioden, Seizoen, Diepte strata en Deelgebieden.
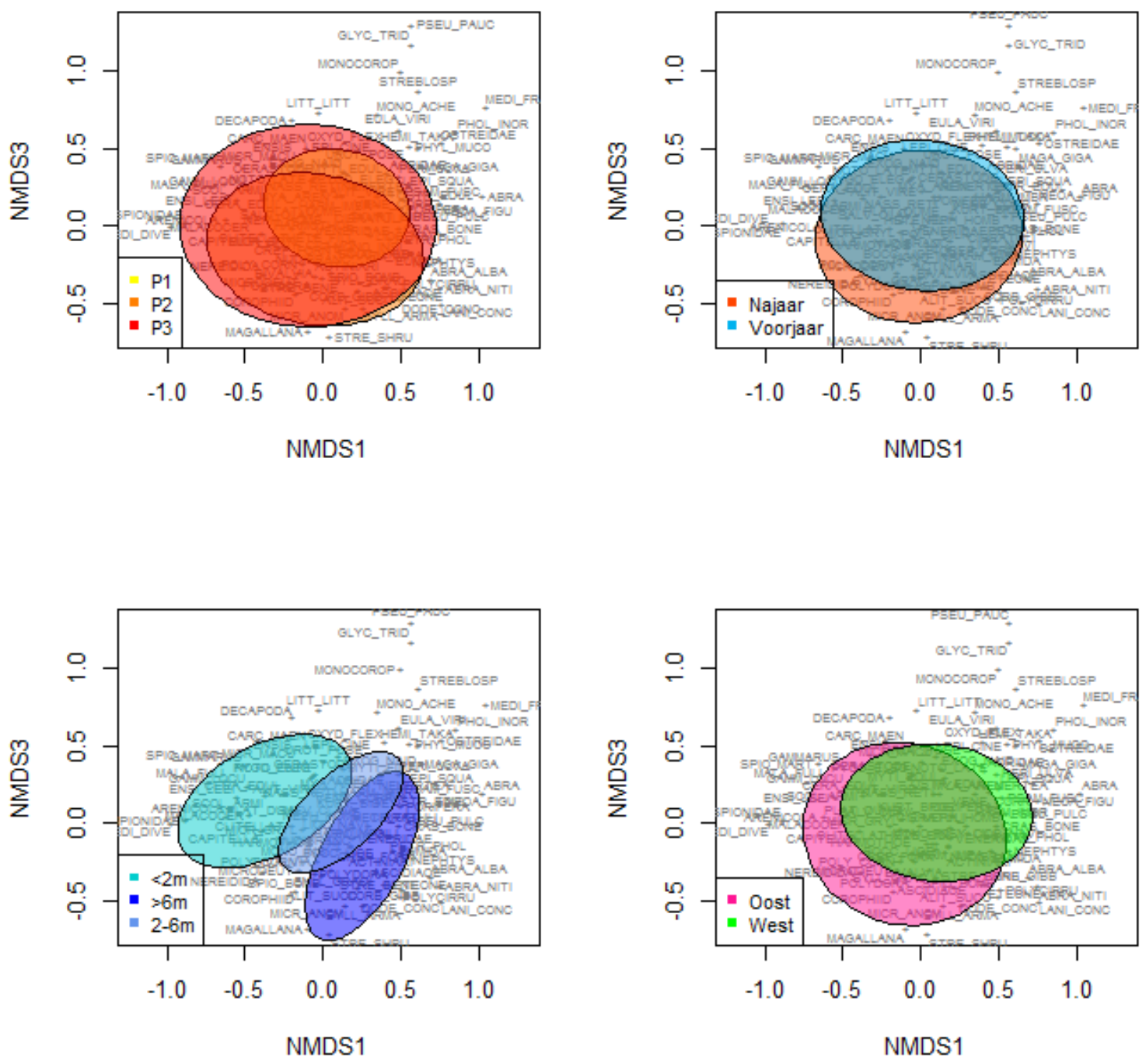
Tabel 12. Belangrijke conclusies uit studies over het Grevelingenmeer gedurende verschillende tijdsperioden.

\begin{tabular}{|c|c|c|}
\hline Rapportage & Periode & Conclusies \\
\hline Holland 1991 & $1980-1990$ & $\begin{array}{ll}\text { - } & \text { Biomassa blijft gelijk } \\
\text { - } & \text { Halvering mosselbiomassa, verdubbeling } \\
\text { biomassa muiltje }\end{array}$ \\
\hline Wattel 1996 & 1990-1994 & $\begin{array}{ll}\text { - } & \text { Biomassa en dichtheden stabiel } \\
\text { - } & \text { Weekdieren dragen } 80 \% \text { bij aan biomassa } \\
\text { - } & \text { (voornamelijk muiltje) } \\
\text { Opkomst muiltje gestabiliseerd }\end{array}$ \\
\hline Hoeksema 2002 & $1990-2000$ & $\begin{array}{l}\text { - Totale biomassa en dichtheden blijven } \\
\text { gelijk } \\
\text { - } \quad \text { Bodemfauna is nog niet stabiel }\end{array}$ \\
\hline $\begin{array}{l}\text { Schaub et al. } \\
2002\end{array}$ & $1990-2000$ & $\begin{array}{ll}\text { - } & \text { Niveau biomassa en dichtheden blijven } \\
\text { - } & \text { gelijk } \\
\text { - } & \text { Verschuivingen in soortensamenstelling } \\
\text { - } & \text { Grevelingen minder geschikt voor } \\
& \text { filtrerende organismen }\end{array}$ \\
\hline Wetsteijn 2011 & $\begin{array}{l}1990- \\
2008 / 2010\end{array}$ & $\begin{array}{l}\text { - } \quad \text { Biomassa stabiel tot } 1999 \text {, daarna dalend } \\
\text { - } \quad \text { 'Verworming' zet door }\end{array}$ \\
\hline Arcadis 2013 & $1990-2010$ & $\begin{array}{l}\text { - Dalende trend biomassa, voornamelijk in } \\
\text { westelijk deel } \\
\text { - } \quad \text { Algemeen dalende trend dichtheid }\end{array}$ \\
\hline
\end{tabular}


Wageningen Marine Research

T: $+31(0) 317480900$

E: marine-research@wur.nl

www.wur.nl/marine-research

Visitors address

- Ankerpark 271781 AG Den Helder

- Korringaweg 7, 4401 NT Yerseke

- Haringkade 1, 1976 CP IJmuiden
Wageningen Marine Research is the Netherlands research institute established to provide the scientific support that is essential for developing policies and innovation in respect of the marine environment, fishery activities, aquaculture and the maritime sector.

Wageningen University \& Research is specialised in the domain of healthy food and living environment.

\section{The Wageningen Marine Research vision:}

'To explore the potential of marine nature to improve the quality of life.'

\section{The Wageningen Marine Research mission}

- To conduct research with the aim of acquiring knowledge and offering advice on the sustainable management and use of marine and coastal areas.

- Wageningen Marine Research is an independent, leading scientific research institute.

Wageningen Marine Research is part of the international knowledge organisation Wageningen UR (University \& Research centre). Within Wageningen UR, nine specialised research institutes of Stichting Wageningen Research (a Foundation) have joined forces with Wageningen University to help answer the most important questions in the domain of healthy food and living environment. 